

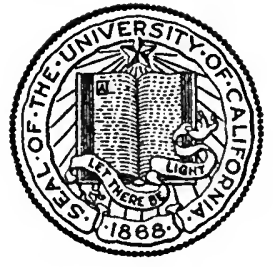

THE LIBRARY OF

THE UNIVERSITY OF CALIFORNIA LOS ANGELES 
c.s 

Digitized by the Internet Archive in 2007 with funding from Microsoft Corporation 



\title{
PERSONALITY \\ IN GERMAN LITERATURE BEFORE LUTHER
}

\author{
BY \\ KUNO FRANCKE, Ph.D., LL.D., LiTT.D. \\ PROFESSOR OF THE HISTORY OF GERMAN CULTURE \\ AND CURATOR OF THE GERMANIC MUSEUM, \\ HARVARD UNIVERSITY
}

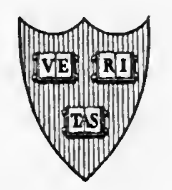

CAMBRIDGE

HARVARD UNIVERSITY PRESS

LONDON: HUMPHREY MILFORD

OXford UNTVERSITy PRess

Igr6 
COPYRIGHT, I9I6

HARVARD UNIVERSITY PRESS 
CHESE lectures were delivered at the Lowell

1 Institute in Boston in January, I915. Four of them were repeated in February of the same year at Cornell University on the Jacob H. Schiff Foundation for the Advancement of German Culture. The whole course was repeated at the University of California in July, I9I6.

KUNO FRANCKE. 



\section{CONTENTS}

\section{CHAPTER I}

The Chivalric Minnesong and the Courtly Epic of the Thirteenth Century . . . . . .

The unity of national life. Literature as an expression of national culture. Jacob Burckhardt's view of the absence of individuality in the Middle Ages. The untenableness of this view. Chivalry the connecting link between medieval collectivism and modern individualism. Walther von der Vogelweide as a forerunner of humanism. The soul life in Hartman von Aue's Poor Henry. The striving for the ideal in Wolfram von Eschenbach's Parzival. The protest against society in Gottfried von Strassburg's Tristan.

\section{CHAPTER II}

German Mysticism of the Fourteenth Century

The democratization of personality through the rise of the middle classes. Individualism in the religious life of the thirteenth century. Cultivation of the inner self, as demonstrated in the Visions of Matilda of Magdeburg. Grasp upon the outer world, as demonstrated by the Sermons of Berthold of Regensburg. The philosophy of Master Eckhart. Its affinity with modern pantheism. The combination of symbolism and naturalism in Heinrich Suso. His affinity with modern romanticists. The climax of the mystic movement in Johannes Tauler. His practical idealism. 


\section{CHAPTER III}

Popular Song and Popular Sattre from the Thirteenth to the Sixteenth Centuries. . 78

Individualistic character of the German folksong of the end of the Middle Ages. Its universality. Its naturalness. Its humanity. The love song. The ballad. The Two Royal Children. Tannhäuser. The Stepmother. The Faithful Sister. Didactic and satirical narrative. The rogue Amis. Meier Helmbrecht. The tide of democratic feeling.

\section{CHAPTER IV}

The Religious Drama of the Fifteenth Century AND DÜRER's Biblical Illustrations . . . II5

The emancipation of the religious drama from its liturgic origins. The influx of secular elements. The bourgeois character of the religious drama. Preponderance of the trivial. Absence of dramatic unity. Power of characterization in details. Effects of contrast. The Vienna Easter play. The Redentin Easter play. The Alsfeld Passion play. The St. John episode. Dürer's relation to medieval legend. The Apocalypse. The Life of Mary. The Passion. The Holy Trinity.

\section{CHAPTER V}

The Humanist Enlightenment: Erasmus . . . . I5I

Climax of individualistic culture at the beginning of the sixteenth century. German humanism. Its defects and aberrations. Its high intellectual aims. Erasmus its most comprehensive representative. Erasmus as thinker. His skepticism. His optimism. The "philosophy of Christ." Toleration. Work for social welfare. Belief in freedom of will. Erasmus as artist. The Praise of Folly. The Familiar Colloquies. 


\section{CHAPTER VI}

The Humanist Revolt: Ulrich von Hutten . . I84 Hutten's ideals of life. His self-characterization in the preface to the satire Nemo $\left(\mathrm{r}_{5} \mathrm{I} 2\right)$ and in his letter to Pirkheimer $\left(\mathrm{r}_{5} \mathrm{I} 8\right)$. His revolutionary activity. His revolutionary writings. His Dialogues. The Spectators. The Bull-killer. The Robbers. Hutten's greatness. Conclusion.

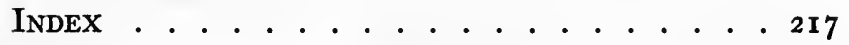





\section{PERSONALITY \\ IN GERMAN LITERATURE BEFORE LUTHER}





\section{CHAPTER I}

THE CHIVALRIC MINNESONG AND THE COURTLY EPIC OF THE THIRTEENTH CENTURY

DERSONALITY and nationality are closely interrelated terms. To think of a nation as a conglomeration of isolated individuals, pursuing only their private aims and their private happiness, is as impossible as it is to think of an individual devoid of a share in the traditions of his folk. National life implies a kinship of aspirations in all fields of human activity, political and social as well as religious, scientific, and artistic. National character, therefore, is both the source and the product of a great variety of individual characters, moved and directed by a common controlling spirit.

These are the fundamental considerations which underlie the following attempt to present some manifestations of German national character in that portentous epoch when the modern world was born, the era from the height of chivalric culture to the Renaissance and the Reformation - the centuries which saw the finest flower of Minnesong and Courtly Epic, in the works of Walther von der Vogelweide, Wolfram von Eschenbach and 
Gottfried von Strassburg; the noblest flight of mystic speculation, in Eckhart, Suso, and Tauler; the richest outburst of popular imagination in folksong and ballad; the fullest sway of realism in the literature of burgherdom; and the boldest assertion of individual reason in the humanist revolt against the Church.

The main trend of my discussion will be the endeavor to trace the development of German personality in all these different kinds of literature - a development which, although it brings the transition from chivalric refinement and elegance to bourgeois commonplaceness and neglect of form, nevertheless in the main represents an ascending line of a continuous widening, intensifying, and deepening of individual life.

Incidentally, my whole narrative will be an implicit criticism of a theory which has been best stated, some fifty years ago, by Jacob Burckhardt in his admirable "Civilization of the Renaissance in Italy," the theory that, in the intellectual history of the modern world, it was the Italian Renaissance which first led to the "discovery of man." "In the Middle Ages," - to paraphrase one of the most significant utterances of Burckhardt's on this subject ${ }^{1}$ - "In the Middle Ages the human mind

1 Cullur der Renaissance, ${ }^{2}$ p. 104. 
was in a state of dreamy half consciousness. It looked at the world, both the inner and the outer, through a veil woven of faith, illusion, and childish prepossession. Man was conscious of himself only as a member of a race, people, class, family or corporation - only through some general category. In the Italy of the Renaissance this veil first melted into air; an objective treatment and consideration of the things of this world became possible; and at the same time the subjective side of consciousness asserted itself with corresponding emphasis; man became a spiritual individual and recognized himself as such."

I do not believe that there is a serious student of medieval literature and art living today who would subscribe fully to such views as these. To demonstrate their insufficiency, one would hardly need to go beyond the reach of French and German sculpture of the twelfth and thirteenth centuries. Anyone who knows that wonderland of grace and beauty, of noble earnestness and spiritual refinement which, in a bewildering wealth of the most varied plastic types of kings and queens, patriarchs and prophets, angels and saints, surrounds the cathedrals of Chartres and Rheims, or who has seen those remarkable, sharply individualized portrait statues of princely donors and patrons which make 
the choir of Naumburg Cathedral a classic gallery of human character, must be convinced that the artists who created these sculptures looked into the world not through a veil of childish prepossessions, but with the clear eye of the discoverer, that they had the fullest sense of personality, that they detected the human in man under whatever guise of nationality or class or station it might appear. In other words, French and German sculpture of the twelfth and thirteenth centuries would suffice to convince us that individuality was not an invention of the Italian Renaissance, nor something foreign to the Middle Ages, but was, on the contrary, a natural growth of medieval life itself.

Nevertheless, it may be not amiss to show this outgrowth of individuality from the very structure of medieval society on a somewhat larger scale, in its application to a comprehensive and widely ramified phenomenon, namely, the development of German literature from the thirteenth to the sixteenth centuries. And this is what I propose to do. In doing so, I shall purposely refrain from an extended comparison of German literature with other literatures, partly because my knowledge of other literatures is too limited to make such a comparison really fruitful, partly because I believe that, if the rise of individuality out of the conditions 
of medieval life is made clear for Germany, a parallel development in other countries is thereby implicitly established.

If we contrast in a broad way the spirit of the Middle Ages with the prevailing spirit of the modern era, it must be admitted that medieval life was dominated by collective consciousness while modern life is dominated by individual consciousness; but it must also be admitted that the very climax of medieval life, the institution of chivalry, forms a connecting link between medieval collectivism and modern individualism. In no other institution of the Middle Ages has the spirit of the submission of the individual to a larger corporate whole asserted itself more strongly than in chivalry; but alongside with this spirit of submission to a corporate whole there are found in chivalry the germs at least of a tendency which ultimately was to set free the individual and raise it above the level of merely corporate existence. Chivalry is service; service to the liege lord, service to the knightly class, service to the church, service to the chosen lady. It rests upon the assumption that compliance with a certain set of class conventions is the true standard of conduct. It finds its highest aim in the scrupulous maintenance of this social standard. This is one side of chivalry; but there is an- 
other side to it. The chivalric ideal, although in the most conspicuous manner an ideal of social decorum, is at the same time an ideal of personal dignity and of personal worth. The canon of virtues which under the undoubted influence of the medieval church came to be the moral code of chivalry at its highest point, comprises the same virtues - the virtues of devotion, faith, magnanimity, steadfastness, valor, generosity, moderation, self-possession - which, as we moderns would say, make the gentleman, or, as the Greeks said,

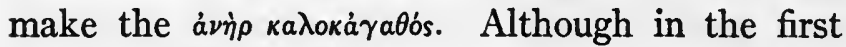
place contributing to develop a strong and clearly defined feeling of class, the moral code of chivalry also contributes to deepen and widen personal life; and thus there arises from the very perfection of the medieval conception of class a state of mind which is at least an anticipation of what we mean when we speak of true humanity.

German poetry of the end of the twelfth century and the beginning of the thirteenth, lyric as well as epic, illustrates in a striking manner this double nature of the chivalric ideal. In the average productions of the Minnesingers, in the majority of the courtly epics, even in the mass of the folk epics, there is a predominance of class feeling and of social etiquette. But from this mass there stand out in- 
dividual poets who, without detaching themselves from the conceptions and ideals of the chivalric class, lend to these ideals of class the whole fullness of their own personality; and from this combination there arise works of universally human significance, works which, like the highest productions of German sculpture of the thirteenth century, need not fear comparison with the best of all ages and nations.

I shall single out from these noblest representatives of chivalric personality in German poetry four names of particular effulgence: Walther von der Vogelweide, Hartman von Aue, Wolfram von Eschenbach, and Gottfried von Strassburg. ${ }^{1}$

Walther von der Vogelweide's poetic activity may be divided into two unequal halves, the first consisting of the brief period of his sojourn at the court of the Austrian dukes at Vienna, from I I 90 to I I98; the second consisting of long years of homeless wanderings from castle to castle, and from land to land, ending with his supposed participation in the crusade of 1228 , after which trace of him is lost. We are probably justified in ascribing to the first of these two periods the majority of his finest and most spirited love songs, to the second the larger

1 For a discussion of personality in the Nibelungenlied and Gudrun, see my Kulturwerte der deutschen Literatur im Mittelalter, pp. $123^{-1} 33$. 
part of his poems dealing with the affairs of Church and State. The important fact is that both in his love songs and in his poems on public affairs there is revealed an individual, holding himself reverently and devoutly within the limits set to him by class tradition and custom, yet within these limits resolutely asserting his own convictions, refusing to be fettered by sham and artificial fashion, fearlessly defending the rights of common humanity, a true freeman in knightly garb, in universality of sympathies, in fully rounded personality a peer of Dante and Chaucer, whom he anticipated by generations.

Perhaps in no artistic productions has chivalry appeared more genuinely human than in some love songs of Walther's in which, while adopting the traditional form of courtly lyrics, he fills this form with his own soul and thus imparts to it a new spirit. What a charming mixture, e.g., of deference to courtly demeanor and social correctness on the one hand and of naïve, childlike joy in nature on the other is embodied in the poem "Sô die bluomen $\hat{u} z$ dem grase dringent " - the comparison of a May morning "when flowers greet with smiles the sun's bright rays" and the little birds sing " in their best manner" with the "noble maiden, fair and pure," who 
wol gekleidet unde wol gebunden, durch kurzewile zuo vil liuten gât, hovelîchen hôhgemuot, niht eine, umbe sehende ein wênic under stunden, alsam der sunne gegen den sternen stât. ${ }^{1}$

How enchanting is the combination of bashful delicacy and social decorum with joyful frankness and daring love in that perhaps best known of Walther's poems in which he makes a young girl recall to herself the blissful hour spent with her beloved among the roses under the linden tree. ${ }^{2}$ How forcible is the contrast, in the poem "Müget ir schowen waz dem meien " between the fastidious description of courtly gayness and the earnest appeal of the heart to the cruel woman whose coldness robs the poet of his bliss.

rôter mund, wie dû dich swachest!

lâ dîn lachen sîn.

scham dich, daz dû mich an lachest

nâch dem schaden mîn.

ist daz wol getân?

owê sô verlorner stunde,

sol von minneclîchem munde

solch unminne ergân! ${ }^{3}$

1 Well clad and well braided, mingles, for pleasure's sake, in company, courteously festive, not alone, glancing around a little at times - like the sun among stars. Kürschner's Deutsche Nationalliteratur (D. N. L.), VIII, 2, p. 16.

${ }^{2}$ Loc. cit., p. 15.

B Rosy mouth, how thou harmest thyself! Let thy laughter cease! Shame upon thee that thou laughest at my discomfiture. Is that well done? Ah for the time lost in such manner if from lovely mouth is to proceed such unloveliness! Loc. cit., p. 27. 
The crown, however, of these love songs in which a conventional conception is made the vehicle of personal experience and emotion seems to me a poem that might be called a spiritualized alba or tagelied. As in the tagelied, the underlying conception of this poem is a meeting of the lovers at night and their separation at the dawn of day. But from the realm of fashionable adventure, which forms the background of this scene in the tagelied, it has been transported by Walther into his own inner life. It is not a stealthy meeting between a knight errant and his paramour; it is a vision that has come to Walther in the stillness of the night, a vision of his having reached the goal of his desires. He has been dreaming of meeting a beautiful maiden in the lonely forest. They gathered flowers together, he placed a wreath of roses upon her head, and as she looked at him, he felt a happiness such as never before.

mich dûhte daz mir nie

lieber wurde danne mir ze muote was:

die bluomen vielen ie

von den boumen bî uns nider an daz gras.

seht, dô muost' ich von freuden lachen,

do ich sô wünneclîche

was in troume rîche:

dô tagete $\mathrm{ez}$ und muose ich wachen. ${ }^{1}$

1 It seemed to me that I never felt more joyful. The blossoms fell ever from the trees about us on the grass. Then I must laugh for joy, 
The beautiful form has vanished; he finds himself alone. But the image of her still hovers before his mind's eye; wherever he goes, it flits about him; and he is impelled to seek for its real counterpart among the living.

From the æsthetic point of view these poems in which Walther weaves his own individuality into the fabric of courtly tradition and aristocratic custom and thus produces a whole of exquisite richness and grace, probably mark the climax of his art. But from the historical point of view, another category of his love poems is equally notable, perhaps even more so, - poems in which the personal element predominates, in which even an opposition to the accepted standards of class etiquette and conduct may be discerned. These poems, naturally, lack for the most part that poise, harmony, and finish, characteristic of the former category; but they compensate us for this lack by telling us of the struggle for the emancipation of the individual which began in Walther's time, which in the sixteenth century overthrew the whole system of medieval hierarchy, in the seventeenth led to the victory of the English commonwealth over the absolute monarchy, in the eighteenth established

since I was so wondrously rich in my dream. Then dawned the day and I must awake. Loc. cit., p. 15. 
American independence, crushed the ancien régime in France, and brought forth the classic epoch of German genius in music, literature, and philosophy; and which, we pray, may convert the present death struggle of European nations into the birth throes of a new era of common humanity.

It seems a far cry from such portentous, worldwide revolutions as these to medieval love songs. And yet it is no exaggeration to say that even in Walther's love songs there is seen not infrequently an anticipation of this great emancipation movement, a protest of the individual against the dictates of society. What else than such a protest is it when, in contra-distinction to the fashionable devotees of the Frauendienst, Walther prefers the word Weib (woman) to the word Frau (Lady). ${ }^{1}$ What else when he scorns a love which does not help to raise his own feeling of personal dignity. ${ }^{2}$ What else when he puts grace above beauty - for grace, he says, makes a woman beautiful; beauty alone does not -; when the glass finger-ring of the simple maid whom he loves is to him more precious than the golden crown of a queen. ${ }^{3}$ In all this we recognize the same spirit which enabled Walther to express more strongly than any of his contempora-
1 D. N. L., VIII, 2, p. 7 I.
${ }^{3}$ Loc. cit., p. ${ }_{3} \mathrm{f}$.
2 Loc. cit., p. 33. 
ries his belief in the brotherhood of all men, be they Christians, Jews or Pagans; ${ }^{1}$ which made him see the foundation of all ethics in the conquering of one's self. ${ }^{2}$ Truly, what Jacob Burckhardt has said $^{3}$ of Dante may with equal justice, nay, considering that Dante lived a hundred years later, with greater justice be said of Walther, namely, that " in reading him we fancy that throughout the Middle Ages the poets had been purposely fleeing from themselves, and that he was the first to seek his own soul."

It is however in his political and ecclesiastical poems, in the poems dealing with the burning questions of the day in Church and State, that Walther's individualism most clearly asserts itself. Sometimes his language has a truly revolutionary ring. When he accuses Pope Innocent III of having instigated civil war in Germany by playing out the two great political parties of the Guelfs and Hohenstaufen against each other; ${ }^{4}$ when he bewails the Constantine Donation as the beginning of the ruin of the Church; ${ }^{5}$ when he compares the Roman See with a sorcerer's abode, a robber's den, a wolf's fastness ${ }^{6}$ - we are indeed reminded of Luther's violent

1 D. N. L., VIII, 2, p. 87.

2 Loc. cit., p. rig.

Cultur der Renaissance ${ }^{2}$ p. 245.
'D. N. L., VIII, 2, p. 96.

b Loc. cit., p. 83.

'Loc. cit., p. ror. 
invectives against the depraved Church of his day. In two of these poems the affinity with Luther is particularly obvious, because Walther protests in them against an evil which wrung from Luther his first great effusion of patriotic wrath and indignation, the extortions of money from the German people made under the pretext of a Peter's Pence or of contributions for a crusade. In the first poem Walther represents the Pope himself, in company with his Roman priests and prelates, glorying over the misery and confusion brought upon Germany by the two rival kings, Otto IV and Frederick II, and laughing in his sleeve over the stupidity of the good natured Germans who meanwhile fill his treasures:

al die wîle fülle ich mîne kasten.

ich hân s'an mînen stoc gement: ir guot wirt allez mîn, ir tiuschez silber vert in mînen welschen schrîn.

ir pfaffen, ezzet hüenr und trinket wîn und lât die tœrschen tiuschen leien vasten. ${ }^{1}$

In the second poem he addresses the contribution box itself as "Sir Box," and curses it as an emissary of the evil Pope who was not thinking for a moment of using the collected money for religious

1 All the while I fill my chests. I have led them about by my stick: their riches will all be mine, their German silver flows into my Roman shrine. Feast on fowl, ye priests, and drink your wine, and let the witless German laymen fast! Loc. cit., p. ro3. 
purposes and was only bent on finding out how many fools are left in German lands. ${ }^{1}$

And yet, in spite of these and similar outbursts of impassioned feelings which impress us as essentially modern, because in them the individual boldly opposes his own views to the acknowledged supreme authorities of public life, it must be said that in these political poems no less than in his love songs Walther reveals himself after all as a medieval man, as a man firmly believing in the sacredness and God-given power of the great public institutions and ordinances, above all firmly believing in Empire and Papacy as the indispensable safeguards of temporal and spiritual welfare. And here again, as in his love songs, the principal charm of his poetry seems to lie in the very union of these two contrasting elements - of corporate consciousness on the one hand and individual consciousness on the other. We have in these poems all the warmth of feeling, all the serene contemplativeness, all the naïve childlikeness which only faith in the accepted forms of life can give; but we also have in them an outlook into those wider fields where man, freed from the fetters of tradition, may exert to the full the whole variety of his faculties and thus develop in himself what is abidingly and universally human.

'Loc. cit., p. 104 
When the poet gives us a picture of himself, ${ }^{1}$ as he is sitting reflectively on a rock, his legs crossed, his arm resting upon his knee, and his chin supported by his hand, and thus muses about the evils of his day: how impossible it is to put mankind into possession of the three greatest blessings of life - honor, wealth, and the grace of God - as long as the highwaymen Violence and Treason are lurking in ambush and are sorely pressing the valiant squires Justice and Peace, - we recognize in medieval form a thoroughly modern conception, the idea of a State founded on right. When the aged Walther sees himself brought back to the scenes of his childhood ${ }^{2}$ and everything now seems so different to him - his playmates, his friends, the fields, the forest, everything different and strange, only the brook is flowing as of yore -, we would fancy hearing a poet of our own times, if these universally human feelings were not followed by a lament upon the sinfulness of the age and an appeal to atone for it by participation in a crusade. And finally in his Leich, ${ }^{3}$ perhaps the most deeply felt religious hymn of German chivalry, what an intimate alliance of naïve childlike faith and free, mature, manly conviction! When has the praise of

\footnotetext{
1 Loc. cit., p. 78.

2 Loc. cit., pp. $125 \mathrm{ff}$.
}

s Loc. cit., pp. $144 \mathrm{ff}$. 
the Mother of God, the sweet, pure Virgin been sung more touchingly than here? By what poet has the whole constellation of symbols by which the Middle Ages loved to surround the mystery of Mary's virgin motherhood - the budding rod of Aaron, the burning bush of Moses, Ezekiel's portal, the dawn consumed by the rising sun, the crystal irradiated by light - been combined into a more resplendent galaxy of images? By whom has the medieval feeling of the need of redemption, the medieval longing for the revival of the "arid heart " by the " holy stream " of the divine spirit been expressed more forcibly and fervently? And in closest union with all this the boldest criticism of the medieval Church, the antithesis between Christendom and Christianity, the emphasis upon personal deed as the only foundation of eternal life. Truly, here Walther von der Vogelweide is revealed to us in his most significant rôle, in his true historical perspective, as a proclaimer of universally human ideals, as a forerunner, or shall we say a spiritual contemporary of the classic German literature of Goethe's and Schiller's days, as a prophet of the reconciliation between traditional belief and free personality. ${ }^{1}$

1 His national feeling also, as attested by the song "Ir sult sprechen willekomen," is based upon the belief in the true humanity of German character. Loc. cit., p. 57. 
Another climax of this same outgrowth of individuality from chivalric tradition is represented in the finest productions of the courtly epic. That the mass of these epics is incarnated spirit of caste and offers very little to touch the feelings common to all men, cannot be denied. In most of these epics the world seems to have been transformed into one continuous opportunity for gallant adventure. Whether the heroes and heroines belong to the legends of the Trojan war or to Celtic or to Oriental tradition, whether their names are Eneas and Lavinia, or Iwein and Laudine, or Terramer and Arabele, makes no difference; they all are nothing but modifications of the one ideal of chivalric etiquette which from France had spread throughout Europe. Few of them call forth human interest; in most of them, particularly the knights of King Arthur's following, the human interest is smothered and stifled by ever repeated phantastic trivialities. What do we care for all these enchanted castles from which gentle maidens are to be rescued; these miraculous fountains in the wilderness near which terrific battles are to be fought for nothing; these giants and dwarfs defying courtly manners; these lions with lamb-like obedience following their masters; these caves of love and fairy groves; these bold abductions and strange deliverances? What is 
it all but an endless monotonous masquerade, a fashionable entertainment of an exclusive caste? How wearisome are these incessant descriptions of armaments and garments; of hairdress and complexion; of the striding, riding, sitting and curtseying of the knights and ladies; of horses, hounds, and monsters; of precious stones and stately halls; of rocky defiles and impenetrable forests. Variegated and motley as are the costumes, the faces of their wearers are nearly all alike. Romantic as are the landscapes, they remain mere scenery, and hardly ever evoke the feeling of affinity between nature and man. Even the best known of these epics of French origin and manner, such as Hartman's "Erec" and "Iwein," nay even Wolfram's "Parzival" and Gottfried's "Tristan," are spoiled for the unsophisticated reader by fashionableness and artificiality, by the lack of artistic selection between the essential and superficial, by the overcrowding of the fundamental theme with a mass of episodes that have little or nothing to do with the human soul, by over-emphasis of what appeals merely to the feeling of caste.

And yet it must be acknowledged that these courtly epics in their best representatives make it especially clear how this very exclusiveness of chivalric feeling leads to the heightening and in- 
tensifying of personal life; how from the mass of colorless and correct society types there arise a few, markedly original and singular, individual types either men who in themselves live out the chivalric morals in their most sublimated form and thereby transform traditional morals into personal morality; or men who, on the contrary, oppose their own self to the traditional morals, who in desire for enjoyment and self-gratification transgress the barriers of accepted respectability, and thereby act as dissolvents of the whole social order from which they themselves proceed. It is instructive from this point of view to analyze Hartman von Aue's "Poor Henry," Wolfram von Eschenbach's "Parzival," and Gottfried von Strassburg's "Tristan."

It will always remain a sad document of the fatal influence of classicist formalism upon pre-romantic German literature that Goethe, the poet of "Iphigenie," should not only not have had any understanding for Hartman's "Poor Henry," but should have shrunk from it with a feeling of positive aversion and something like fear of contagion. ${ }^{1}$ For where in all the world is there a poetic theme more nearly akin to the theme of Goethe's "Iphigenie"? Where, except in Goethe's "Iphigenie," has the victory of a pure heart over a terrible fate, has inner

1 Goethe, Tag-und Jahreshefle, 1811, Werke, Hempel, xxvii, 203. 
recovery and purification been more touchingly represented than in Hartman's "Poor Henry"? Nor is the universally human value of this poem impaired by the fact that it holds itself strictly within the bounds of chivalric conceptions and is, indeed, a perfect expression of their religious elements.

It is impossible to reproduce the charm of this poem - which, by the way, is the only one of Hartman's works based upon native German tradition - by an analysis of its contents. Every line in it is genuine poetry, the composition of the whole of a simplicity, perspicuity, and gracefulness, such as no other narrative poem of this period betrays. All glaring contrasts between health and disease, happiness and misery, riches and poverty, good and evil - contrasts which lie close enough to the plot of the story - are scrupulously avoided. The terrible disease of leprosy by which Sir Henry is visited, is not conceived of as a punishment for his sins. He is not a hard, cruel, arrogant lord; on the contrary, he is a nobleman as he should be, "a flower of youth, a mirror of joy, an adamant of steady faith, a crown of courtly manners." 1 And his guilt consists only in this that he does not, like Job, accept patiently and trustfully the fearful trial by which God wants to test him, but revolts

1 Verses $60 \mathrm{ff}$. 
against it and gives himself over to wild, defiant misery. His misery turns into utter hopelessness when he hears from the physician at Salerno that he can be healed only by the heart-blood of a pure maiden who of her own free will would give her life for him. He retires to a lonely farm in the Black Forest to await his end in mute resignation. But here again, we are spared the crude effects of pathological naturalism. There is no shrill discord between the comfortable life of the stately Swabian farmhouse, with its sturdy master, the industrious housewife and their healthy, beautiful children, and the wretchedness and despair of the lonely sufferer. On the contrary, a spirit of human fellowship and mutual understanding is spread over their intercourse; and golden poetry surrounds the figure of the lovely child, the eight year old daughter, who instinctively clings to the poor stranger, follows him everywhere, and rejoices when he calls her his "little spouse" and presents her with toys and nicknacks.

How simple and how deeply affecting is what now follows: the series of soul-stirring experiences which reaches its climax in Henry's recovery and his union with his deliverer.

The child is sitting at his feet when one day, three years after his arrival, he tells the parents his 
sad story, ${ }^{1}$ ending with the account of the crushing declaration of the physician at Salerno which robbed him of every hope - for how could a girl be willing to shed her blood for his sake? The child listens intently; all day long she broods over his words; at night, lying at the foot-end of the parental bed, she cannot find sleep; she sighs and sighs, and "the rain of her eyes watered the feet of the sleeping ones." The parents, aroused, bid her to be quiet: of what avail was lamenting ? to help the poor knight was impossible. So the child is silent; but all night long she remains awake, and throughout the whole next day she has no other thought, and in the following night she weeps and weeps again, until suddenly there comes the illumination: I must die for him, I am destined to save him! And now she awakens her parents again and imparts to them her resolve. It is moving to see how the parents at first shudder at the frightful thought, how they remind the daughter of her filial duty and beseech her not to break their hearts; ${ }^{2}$ but how they come to recognize the divine spirit speaking out of the child, and gradually resign themselves to give up their dearest, and let the will of God be done. Cold with misery, speechless, they sit at her bed, and yet proud that this is their child, that ${ }_{1}^{1}$ Verses 378 ff.

2 Verses 565 ff. 
through her death the divinity in man will be glorified. ${ }^{1}$

And finally, the solution of the whole. What could be freer from conventional externalities, what could be more deeply experienced than the way in which Henry's recovery is brought about? Outwardly, to be sure, it seems to be the consequence of the willingness of the girl to sacrifice herself; in reality, it is the consequence of his own inner regeneration. Only after long resistance and grave scruples, whether he could accept her sacrifice, has he gone with her to Salerno. The physician has convinced himself by severe scrutiny that the girl of her own free will has decided to die and to win the crown of martyrdom. She has been stripped and bound upon the table, the physician sharpens his knife. Henry stands before the door, he hears the noise in the room, he looks through a chink in the wall, he sees the sweet creature that wants to die for him - and he is seized in his innermost being, he is given, as the poet expresses it, ${ }^{2}$ "a new mind." Till now he has hardened himself against God's decree, he has felt his visitation as deep injustice, even the pure goodness of the lovely maiden has not changed his spirit. Now it suddenly comes over him: What am I that I dare to

1 Verses 865 ff.

2 Verse 1245. 
defy God's will! He forgets his own suffering over the sympathy with another being; he has inwardly been restored to health. And thus the poem ends with a series of charming idyllic scenes: ${ }^{1}$ the homeward journey of the two together, the return of Henry's youthful strength and manly beauty, the joyous welcome by the good Swabian countrymen, the calling of the clan for the selection of a bride, the assembly of chattering and gossiping cousins, and Henry's stepping forth into their midst, embracing his deliverer before them and proclaiming her as his wedded wife.

It seems to me in no wise improper to place the poet of "Poor Henry" upon the same level with the poet of "Iphigenie." Goethe as well as Hartman have lifted a subject resting upon conventional conceptions into the sphere of spiritual personality. As in Goethe's drama the delivery of Orestes from the pursuit of the Furies proceeds from the mental revolution wrought in him through contact with the pure soul of Iphigenie, so the bodily recovery of the knight Henry is the result of an inner rebirth brought about by the sight of pure human devotion and self-sacrifice. Both poems glorify the triumph of the inner life over outer conditions, both are symbols of the reconciliation between matter and spirit.

1 Verses I38r ff. 
If Hartman von Aue's "Poor Henry" is a poem of the human soul, we have in Wolfram von Eschenbach's "Parzival" a poetic representation of the striving for firmness and completeness of human character. In spite of all external and trifling appendages, in spite of all the confusion of fantastic episodes, this poem shows us the unremitting pressing forward of "steadfastness" and "undaunted courage," the unremitting struggle against "doubt" and "faithlessness," the unremitting "chase after the body's crown and the soul's renown" 1 in unforgettably impressive and monumental figures. Dürer's knight, fearlessly riding into the world in company with Death and Devil, has in this poem a forerunner endowed with the full glory of medieval romance.

As is well known, the general outline of the whole and much of the detail of Wolfram's "Parzival" are based upon the "Perceval" of Chrestien de Troyes. If it nevertheless has been asserted,- - and justly so, I believe, - that the ideal of chivalry stands out more humanly and with stronger appeal to fundamental emotions in Wolfram's poem, this assertion rests upon the conviction that Wolfram's hero experiences the problems of chivalric morals more deeply, that he maintains steadfastness more

1 Book IX, II7I ff. 
firmly, that he tastes bitterer doubt and purer joy, and thus becomes a more fully rounded personality. Three phases of Parzival's inner development may be considered as illustrations of this fact: his youthful adventures, his marriage, and his search for the Grail.

The youthful Perceval of Chrestien's also is a captivating, irresistible figure, a "vallet sauvage," proving the uncorrupted sturdiness of his nature even in all his tomfooleries and reckless escapades. Such scenes as where he rides into a tent in which a "damoisiele," the " amie" of the knight Orgueillous, is asleep, thinking that it is a church; ${ }^{1}$ or where he lets his horse trot straightway into the hall of King Artus, so near to the king himself that the horse's head knocks off his hat ${ }^{2}$ - these and similar scenes are related with happy humor. Nor does this youthful romp lack in finer feelings. He is deeply stirred by the rebuke inflicted upon the lady at the court of King Artus for laughing at his eccentric appearance. And in the midst of his adventurous course he is seized by a sudden longing for his mother whose breaking down at his departure he had so heartlessly ignored. The full poetry, however, of this tale of the happy-go-lucky simpleton is revealed only in the form given to it by

${ }^{1}$ Perceval, ed. Potvin, verses 1849 ff. 2 Loc. cit., verses 2095 ff. 
Wolfram. Here we feel from the beginning: in this dreamy, delicately sensitive boy who is so affected by the singing of the birds in the forest that he runs home weeping, he knows not why; ${ }^{1}$ in this innocent youth who, riding out into the world, follows the farewell precepts of his mother so literally that he constantly misses their meaning and constantly incurs ridicule; in this pure fool to use Richard Wagner's felicitous expression there lives an unconscious moral impulse, an instinctive belief in everything noble and sacred, which makes us feel assured of his development into a strong, trustful, independent man. When the young simpleton in all innocence snatches a kiss from the charming Jeschute; ${ }^{2}$ when he takes the deepest pity in the grief of Sigune over the death of her beloved, although both are entire strangers to him; ${ }^{3}$ when his manly valor and beauty dazzle the whole court of Nantes while he remains entirely unconscious of it; ${ }^{4}$ when at the castle of Gurnemanz he receives the chivalric instructions of the old knight so eagerly and reverently that, at his departure, his host feels as though he were losing a son; ${ }^{5}$ when the beautiful princess Kondwiramur, pressed by her enemies, turns to him for help and,
1 Book III, $70 \mathrm{ff}$.
4 Loc. cit., 937 ff.
2 Loc. cit., 413 ff.
Loc. cit., 1623 ff.
3 Loc. cit., $665 \mathrm{ff}$. 
disregarding all proprieties, herself in her nightgown, kneels down at his bed, and her appearance arouses in him only feelings of unselfish sympathy and the ardor to avenge her ${ }^{1}-$ we understand what the poet means by saying:

\section{got was an einer süezen zuht, dôr Parzivâlen worhte. ${ }^{2}$}

Parzival's marriage to Kondwiramur is perhaps the most original feature of Wolfram's poem; in none of the other Parzival epics has the relation between husband and wife found as fine an expression. Through his marriage, Parzival is charmed against all the worldly allurements to which his counterpart, the gallant Gawan, eagerly yields. The thought of his beloved wife accompanies him in all his adventures. Not only in that beautiful episode when the drops of blood in the snow remind him of the tears in her white face, ${ }^{3}$ but again and again her image rises before his soul and makes him sure that there is no room in his heart for faithlessness. But the tragedy also of his life, the agony of his lonely wanderings after the curse pronounced upon him by the messenger of the Grail, is aggravated and intensified through the thought of his

1 Book IV, $387 \mathrm{ff}$.

2 God was in a joyous mood, when he created Parzival, Book III, 982.

Book VI, 80 ff. 
wife. For his errors have plunged not only himself, but her as well into misery, and now, separated from her, in the darkness of his lonely life he carries her despair with him as well as his own. It is therefore an act of true redemption and soul delivery when through Parzival's final winning of the Grail the reunion with his wife also is brought about. Few scenes of the poem surpass in depth and purity of sentiment the description of this happy meeting. Parzival has heard that Kondwiramur is on her way to greet him in the castle of the Grail. With small escort he starts out to meet her. All night long he rides through the forest. At dawn he sees her camp. He enters her tent and finds her still asleep, at her side their two little boys.

si blicket ûf und sah ir man, si hete niht wanz hemde an, umb sich siz teclachen swanc, fürz pette ûfen teppech spranc Cûndwîramûrs diu lieht gemâl. ouch umbevienc si Parzivâl. man sagte mir, si kusten sich. ${ }^{1}$

She bids him welcome, she would like to be angry with him, and cannot, she praises the day which

1 She looked up and saw her husband, she had nothing on but her nightgown, about her she flung the sheet, from the bed upon the carpet leapt Kondwiramur, the lovely spouse. And Parzival embraced her; they tell me, they kissed each other. Book XVI, 4I9 ff. 
has brought her this embrace and has ended all her woe. Now the boys also awaken, and Parzival takes them upon his arm and kisses them. Then, however, the little ones are carried away, the servants leave the tent, and husband and wife remain alone together until the high morn.

Finally, Parzival's quest of the Grail. Here also it must be said that Wolfram's poem deepens the moral conceptions of Chrestien, although here also he follows him in the outline of the action. Wolfram's Parzival, like Chrestien's, has failed to ask the question upon which depends the winning of the kingdom of the Grail, because he keeps too closely to the rules of chivalric conduct which the knight Gurnemanz has given him. Like Chrestien's Perceval, he is cursed for this omission by the messenger of the Grail. Like him, he now sets out to win the Grail in spiteful defiance. But all these happenings are in Chrestien's poem somewhat conventional. The question to be asked refers with him to the wonders of the Grail. "Qui on en servoit ?" is the formula, "Whom serves one with the Grail ?" - in other words, it is a question concerning the meaning of the Grail ritual. With Wolfram, it is a question of human sympathy, of sympathy with the fearful suffering of Anfortas,

1 Perceval, Verses 4423, 4472. 
the King of the Grail, who because he has profaned the sanctuary has been visited by a terrible disease and can be healed only by him who inquires for the cause of his torments. This question of human sympathy Parzival fails to ask because he is led astray by the precept of courtly silence. For this lack of human sympathy with the suffering of others he is himself thrust into misery and distress. And much more violently than Chrestien's Perceval is he shaken thereby. He has erred unknowingly, nay, he has fancied that by obedience to the precept of courtly silence he fulfilled a moral command. His condemnation, therefore, seems to him cruel injustice. He doubts in God's omnipotence and goodness. He defies him. "What is God?" he exclaims.
wær der gewaldec, sölhen spot het er uns pêden niht gegeben, kunde got mit kreften leben. ich was im dienes undertân, sît ich genâden mich versan. nu wilich im dienest widersagen: hât er haz, den wil ich tragen. ${ }^{1}$

And thus he sallies forth, bent upon conquering by sheer force and prowess the crown of life which can

1 If he were mighty, such mockery he would not have brought upon us both, could God live in power. I served him in faithful service ever since I could think of his mercies. From now on I renounce his service. If he has hatred, hatred I will bear. Book VI, $\mathbf{I}_{562} \mathrm{ff}$. 
be won only by humility of heart and as a gift from above.

Beautiful is the gradual transformation and purification of soul which through a series of inner experiences, leads to his final victory. First, another meeting with Sigune, ${ }^{1}$ now living as a recluse by the grave of her slain lover: the sight of her selfsacrificing, consecrated life, and her calm, consoling words awaken in Parzival also a sense of humility and a gentle hope. Then, the meeting on Good Friday morning with the old knight and his family, barefoot and in sackcloth, being on a pilgrimage to a shrine of mercy: they call up in Parzival's mind the memory of long forgotten means of grace. Then the stay with the hermit Trevrizent: ${ }^{3}$ in the intercourse with this venerable man of wisdom, who has sought refuge from the tumult of chivalric battles in the solitude of the forest, Parzival finds himself again. By him he is instructed about God's mysterious and merciful ways; by him he is introduced into the secrets of the Grail, the guilt and the fearful fate of King Anfortas, and thereby into the meaning of human guilt and penance at large; through Trevrizent he becomes conscious of what he himself has been guilty of toward Anfortas, and

Book IX, 62 ff.

3 Loc. cit., $585 \mathrm{ff}$.

2 Loc. cit., 396 ff. 
the desire arises in him to atone for it, to deliver him. Thus Parzival leaves the hospitable hermitage as one reborn. He strives for the Grail, but not any longer in blind defiance and with hardened heart. $\mathrm{He}$ has tasted the bitter tragedy of life, but from the well of suffering he has drawn sympathy with all human experience. For a second time he reaches the Castle of the Grail. From his innermost heart, moved by genuine pity, he asks the question: ${ }^{1}$ "Anfortas, what ails thee ?" Anfortas recovers. Parzival himself has become worthy of the crown which first in blind inexperience he had trifled away, which then in futile defiance he had tried to force. He has been purified by life. Through doubt and despair he has returned to the old certainty of faith, he has made the ideal of chivalry a part of his own spiritual personality.

If in Wolfram's "Parzival" we observe how the intense development of chivalric morals leads to the heightening of individual morality, and how the heightening of individual morality in turn leads to a still further development of chivalric morals, we see a process diametrically opposite in the "Tristan" of Gottfried von Strassburg. Here the overstraining of chivalric culture leads to a revolt of the individual against the barriers of society and thereby

1 Book XVI, 269. 
to a dissolution of the moral foundations both of social and individual life. While Wolfram with soul-stirring power calls up to view the gradual rounding out and persistent upbuilding of a character clinging to the chivalric ideal, Gottfried with finest psychological art depicts the delight and the woe, the demoniac charm and the consuming fire, the guilt, the madness, and the curse of destructive passion. No other work of medieval poetry impresses us so deeply with the tragedy of human civilization which by its very striving for ever higher refinement again and again is driven to selfdestruction and to the annihilation of all true culture.

The individual and society cannot be contrasted more sharply than in this poem. On the one hand, chivalric society with its complicated code of refined conduct, absorbing every thought and controlling every action. Everything in this chivalric world seems to be teeming with culture and decorum; the whole life dissolves itself into elegant attitudes, courteous forms of address, and obliging politeness. Tristan himself appears as a veritable paragon of aristocratic demeanor and correctness. He is a perfect cavalier and huntsman; ${ }^{1}$ he sings, plays the harp and other stringed 
instruments; he speaks Latin, French, German, Danish, Irish and who knows how many other languages. ${ }^{1} \mathrm{He}$ and his companions are saturated with sententious virtuousness, magnanimity, and noble intentions. ${ }^{2}$

To be sure, there are darker passages in this life; there is no lack of exciting episodes. Tristan as a boy is abducted by pirates. Morold, the duke of Ireland, annually levies from Cornwall the cruel tribute of thirty noble youths, and only Tristan's victorious combat with Morold puts a stop to this barbaric usage. Isolt's father has made the fight with a monstrous dragon the condition of winning her hand, and thousands of knights have perished before Tristan kills the beast. But even these catastrophes of life seem, as it were, levelled off by courtly etiquette; they have come to be a social pastime, romantic adventures, sportlike interruptions of the monotony of every-day existence. Chivalry, in short, shows itself here in the most roseate light. An accepted moral code simplifies all decisions, smooths all difficulties, banishes everything ugly, loud and uncouth, removes misery and distress into a far distance, and spreads a general feeling of security and belief in the permanency of this brilliant, refined society.
1 VI, $3664 \mathrm{ff} ; 3687$ ff.
2 VIII, $5020 \mathrm{ff}$. 
Suddenly an elemental passion breaks into this realm of gentle breeding and perfect manners; and all at once these elegant and cultivated people reveal themselves in their primitive, brutal selfishness, and with one stroke demolish the whole artificial structure of their social articles of faith. The external occasion of this sudden revulsion is the magic potion which Tristan and Isolt drink on the vessel upon which Tristan is to convey Isolt to King Marke as his bride-elect. Its psychological justification lies in the fact that the overstraining of social refinement is apt to bring about, as individual reaction, a moral indifference which detaches the individual from all social bonds and makes him a prey to his own caprice and desire.

With supreme art the poet depicts how Tristan and Isolt succumb to this fate. For a time they try to resist. Tristan thinks of what honor demands of him, he reminds himself of his feudal duty toward Marke, the man who has shown him nothing but kindness, has become a second father to him, and trusts him implicitly. He flees the sight of Isolt, he roams in thought all over the world to find some sort of diversion; but he is always brought back to the one feeling, and when he looks into his heart, he finds there " nothing but Isolt and Love." 1 Isolt

1 XVI, ri79r. 
also at first struggles against passion. She is consumed with shame, she wishes to die. She wishes she could hate Tristan, as she used to hate him why didn't she kill him then? But she is like a bird that has been caught in the lime. "She felt her senses sink, she tried to lift herself up, but she was held back and drawn downward. She turned hither and thither, with hands and feet she strove, but all the more her hands and feet sank into the blind sweetness of Tristan and Love." 1

And thus both, with will power benumbed and in raving ecstasy, surrender to the blind impulse that draws them together. From here on there is nothing left in them but love's madness. All moral scruples are silenced. Brangaene, Isolt's faithful servant and confidante of her passion, is forced to take her place in the bridal night at Marke's side; and now Isolt, for fear of being betrayed by her, does not even recoil from trying to put her to death. The whole social fabric with its courtly etiquette and refinement appears from now on as one colossal lie. While outwardly life takes its ordinary course, the principles on which it rests are constantly most shamelessly mocked and violated. Every ruse, every breach of faith appears permissible in order to deceive Marke, the ever-forgiving one, and to

$1 \mathrm{XVI}, \mathrm{II} 807 \mathrm{ff}$. 
give the lovers an opportunity for a stealthy rendezvous. This goes so far that Isolt, trusting in "God's courtliness," ${ }^{1}$ i. e., in his chivalrous forbearance with her criminal life, at a solemn ordeal commits open perjury and thereby makes the Church itself an accomplice of her evil ways. In short, the whole career of the two, since that fateful break with society, is tuned to the frenzy that resounds in Tristan's delirious love stammering of the "sweet poison which brings him death in Isolt."2 They both are morally poisoned, and to both love brings, not immortal life, but spiritual extinction.

That the poet, however, should surround this love of Tristan and Isolt with all the splendor of romantic poetry; that he should contrast it as the only true love with the trivial love conception of chivalric society; ${ }^{3}$ that he should glorify the sufferings which it brings and excuse the errors to which it leads; that he should represent Tristan and Isolt as martyrs of the inner life and as victims and outcasts of soulless convention - this shows how completely the chivalric ideal has paled for this poet, what an empty form chivalric morals have become to him, how passionately and exclusively the fate of the individual man absorbs him.

$1 \mathrm{XXIV}, 15,556$.

${ }^{3}$ I, 45 ff.; 2 II ff.

2 XVIII, 12,498 ff. 
The detachment of personality from the corporate consciousness of chivalry appears here as an accomplished fact.

All too soon chivalric culture decayed. Its decay coincided with the political and social decline of the class with whose prosperity it was connected. But its most valuable outgrowth, the development of personality, has not been lost. This development was taken up and carried further by the class which, from the end of the thirteenth century, rose to a leading position in German life, the burgherdom. 


\section{CHAPTER II}

\section{GERMAN MYSTICISM OF THE FOURTEENTH CENTURY}

$\mathrm{T}$ the preceding chapter $\mathrm{I}$ tried to show that 1 the modern conception of personality has its germ in medieval chivalry; that the laws of conduct which to us appear as demands of the individual human reason, historically are derived from the chivalric ideal of social decorum. The centuries following the climax of chivalric culture, the centuries marked by the ascendency of burgherdom and peasantry, are the epoch in which this aristocratic ideal of a refined personality, nobly conscious of its duties and rights, is democratized, is applied to a wide sphere of popular activities, and thereby for the first time comes to be a power in the life of the masses. These centuries, then, the thirteenth to the sixteenth, - are the true incubation period of modern thought and feeling.

If we speak of the individualism of German burgherdom and peasantry in the fourteenth and fifteenth centuries, we must not forget that this word, individualism, in this connection means something very different from what it means if ap- 
plied to Rousseau or to Nietzsche. As little as the knight of the twelfth century, did the citizen or the peasant of the fourteenth think of himself as an isolated individual; fully as much as the knight did he feel himself above all a member of a corporative whole - the city, the patrician family, the guild, the rural parish. No man in those centuries seriously doubted that the institutions under which he lived were divine institutions, lifted far above the intellect of the individual and inaccessible to his limited judgment. No man in those centuries would have admitted that he conceived of nature otherwise than as the creation of an extra-mundane God, a creation meant to glorify its creator and to please the eye of man. It was left for the eighteenth century to produce a consistent individualistic philosophy: to think of the individual as an independent, autonomous being; to derive the origin of state, church and society from the conscious will of these independent individuals; and to conceive of nature as a system of individual forces, resting in themselves and mutually maintaining each other.

But this much may be said. The individual person and the individual fact obtain a deeper significance, exercise a broader influence, and stand out in stronger relief in the epoch of citizen and peasant 
ascendency than had been the case in the epoch of chivalric culture. The quicker pulsation of life in the cities, the greater variety of social types and conditions, the more intense friction between man and man - all this leads to spiritual stirrings of the masses which cannot help unfettering the individual. It is therefore not surprising that the literature of this epoch shows an intensity, a freedom, and a power of individual emotion and observation which is hardly paralleled in the literature of chivalry. With deeper fervor and more rapt intuition than their scholastic predecessors do the German mystics of the fourteenth century set out to solve the riddles of the universe. More fully and more truly than in chivalric lyrics does life ring out in German folksong of the end of the Middle Ages. More trenchantly and boldly than even Walther von der Vogelweide does the bourgeois satire castigate the follies and vices of human society. And with greater minuteness of actual detail as well as with wider scope of emotion than ever before is the Christian legend visualized in the religious drama of the fifteenth century. These are some of the characteristic phases in the development of German literature in the closing centuries of the Middle Ages which we shall study in the following chapters. We shall begin by trying to 
obtain a somewhat clearer view of how personality is revealed in the mystic movement.

The climax of German mysticism in the fourteenth century is preceded in the thirteenth century by a remarkable series of religious phenomena connected on the one hand with the deepening of the inner life in the large number of newly founded semi-clerical lay organizations devoted to the cultivation of the soul, on the other hand with the firmer grasp upon outer life exercised by the new method of preaching as practised by the popular orders of the Franciscans and Dominicans.

Perhaps the most influential among the lay organizations just mentioned was an association of women, the order of the Beguines which from the Netherlands, its starting point, gradually spread over all of Germany, in such numbers that in Cologne, for instance, there lived about the year I $25^{\circ}$ more than a thousand Beguines, while more than forty convents of Beguines are testified for Strassburg in documents of the thirteenth and fourteenth centuries. The Beguines do not irrevocably renounce worldly possessions or marriage. They retain their property rights; but they devote their property to the common aims of the order: helping the poor and the sick. They may leave the order and marry; but as long as they belong to the order, . 
they remain single. In other words, they try to combine the discipline of the monastery with the freedom of secular life. They seek God in humility, in contemplation, in the love of one's neighbor, in self-abnegating work for the community.

What intensity of religious feeling, what ecstasy of spiritual longings there were created in the common life of these humble seekers of the divine, may perhaps best be illustrated by the personal effusions of a woman who from 1235 to 1265 , that is for thirty years, was a member of a Beguine convent in North Germany, Sister Matilda of Magdeburg. The record of her emotions and visions is contained in a singular little book of hers bearing the title "The Streaming Light of the Godhead," which belongs to the most profoundly moving and the most genuinely authentic autobiographical confessions of the world's literature. Its keynote is the bliss and the woe of divine Love; the wounds which it inflicts, the sacrifices which it demands; and the unspeakable joy of the perfect life to which it leads. The chivalric Minnesong, the passion of a Tristan, appear like frivolous dallying with artificial sentiments if compared with the bitter torments and the rapturous delights of this spiritual Isolt. "Divine Love," she exclaims, " thou hast chased me and captured me and bound me and 
wounded me so deeply that I can never recover. Tell me, am I ever to be delivered from thee ?" And Divine Love answers:

das ich dich jagete, das luste mich; das ich dich vieng, des gerte ich; das ich dich bant, des frowete ich mich. ich han den almehtigen got von dem himelrich getriben und han ime benomen sin mœnschlich leben; wie mœgest du, snœder wurm, vor mir genesen. ${ }^{1}$

So, then, Matilda abandons herself to the one feeling of endless desire for her heavenly master, her mystic bridegroom. Her chamberlains, the senses, announce to her his coming, and counsel her to prepare for him, by contrition, by self-chastisement, by martyrdom, by a life of holy solitude, by worship of the saints and the angels. All this she is prepared to take upon herself; but satisfaction she cannot find in any of these practices. What she craves is complete absorption in the Godhead, absolute union with the Infinite. "Woman, woman," the senses call out to her, " take care not to over-reach yourself. The fire of the divine will blind and consume you." But she answers:

1 That I chased thee, that was my desire; that I captured thee, that was my wish; that I bound thee, that was my joy. I have driven almighty God from Heaven and have taken from him his human life; how couldst thou, poor worm, withstand me. Offenbarungen der Schwester Mechthild von Magdeburg, oder das fiessende Licht der Gottheit, herausg. von P. Gall Morel, i, 3. 
der visch mag in dem wasser nit ertrinken, der vogel in dem lufte nit versinken.

das gold mag in dem fúre nit verderben, wan es enpfât da sin klarheit und sin lúhtende varwe. got hat allen creature das gegeben, das si ir nature pflegen;

wie mœhte ich den miner nature widerstan ? ${ }^{1}$

It can truly be said: This woman has drunk the magic potion of heavenly love. She has become entranced thereby. The limits of the earthly have vanished for her. She lives in visions of the eternal, and in the visions of the eternal she finds herself. This woman and her spiritual kindred - of which there were many all over Germany - are conclusive proof that the heightening of personality which proceeded from the refined etiquette of chivalry did not remain confined to chivalry, but affected the deeper currents of religious life as well. In the mystic movement of the fourteenth century these under-currents were to come to the surface and to assume most impressive proportions.

Next to this deepening of the inner life cultivated by lay organizations of humble God seekers like the order of the Beguines, there was another

1 The fish cannot drown in the water; the bird cannot sink in the air; the gold cannot be destroyed in the fire; it acquires therein its purity and its lustre. God has given to all beings to live according to their own nature; how should I then strive against mine? Loc. cit., i, 44 . 
popular force in the thirteenth century which prepared the way for the activity of the great mystics in the fourteenth century: the new method of preaching introduced by the Franciscans and Dominicans.

Previous to the establishment of these orders, the sermon played a very limited and meagre part in German church service. It consisted in a formal exegesis of the biblical text prescribed for each Sunday or Holiday; it drew its material mainly from scanty excerpts from the Latin Church Fathers; and it was preached exclusively by members of the parish clergy and their superiors. The new popular orders were the first monastic orders to be granted the privilege of preaching, and they exercised this privilege in the widest and freest manner. The Franciscan or Dominican preacher would go about from town to town; he would speak on whatever text he might choose, on any day, in any place, in the public square, before the city gates, from towers, from trees; and it is easy to see how this freedom of movement would tend to widen the range of his thought, to bring him into closer contact with the world, to impart to his speech a fuller grasp of life.

The typical representative of this new method of sermonizing is the Franciscan Berthold of Regens- 
burg, the greatest orator of the thirteenth century. No medieval preacher, if we except Bernhard of Clairvaux, seems to have attracted and stirred the masses in like manner. His wanderings included many countries. Apart from his native province Bavaria, his activity is attested for the Palatinate, for Alsace, Lake Constance; for the Swiss cantons of Aargau, Zürich, the Grisons; for Austria, Moravia, Bohemia, Silesia, Thuringia. Everywhere the people flocked to hear him. The manuscript of one of his sermons contains the marginal note: "Many thousands listened to it at Zürich, before the Gate"; and in other manuscripts audiences of forty, sixty, a hundred, nay two hundred thousand people are recorded - statements, which even though they are palpable exaggerations, show the extraordinary influence exerted by this man. Not a few fancied they saw a halo around his head while he was speaking; moved by his speech, many a proud knight would return stolen church property, many a frivolous courtesan would abjure the lusts of the world. And Berthold apparently knew how to turn such a moment of success into a powerful appeal to the feelings of the masses. Once when his thundering words have terrified one of his hearers, a poor daughter of sin, to such a degree that she breaks down, he calls out to the 
assembled populace: "Who of you will take this repentant daughter for a wife? I-will endow her with a marriage portion." A man steps forward to accept the bargain. Berthold promises ten pounds; and, having no money himself, he sends some men through the crowd to collect the sum. While the collection is being taken, he suddenly exclaims: "Enough! we have the money that is needed." And lo! exactly ten pounds, not a penny less or more, had been collected. ${ }^{1}$

Berthold of Regensburg also, no less than Matilda of Magdeburg, is imbued with the belief in the unseen. For him, too, the world is a symbol of the spirit; for him too the outer happening is a reflex of the inner life. The song of the nightingale, he believes, fertilizes the egg which his mate is hatching while he sits in front of the nest; the spots in the moon, he thinks, are the tears of Mary Magdalen; the constellation of the dipper is to him the fiery chariot upon which the human souls are carried to heaven. And all the grandeur, all the splendor of the world is nothing compared with the spiritual beauty that emanates from the face of God illumining the heavenly host.

But, much as Berthold loves to revel in such descriptions of the unseen and the spiritual, his chief

1 Berthold von Regensburg, ed. Pfeiffer and Strobl, i, p. xxiv. 
interest is after all directed toward the actual and the palpable. In Matilda of Magdeburg we saw the widening of personality toward the life within, the discovery of a world of inner visions; in Berthold we see the widening of personality toward the life without, the transmission of the inner self into the current of outer experience. Berthold is driven by the impulse to convert and to proselyte; he would like to realize the image of the perfect life which he carries in himself; he deeply feels how wide the distance is between his ideal and common reality. All this lends to him a keenness of observation for the appearances of the outer world, for the peculiarities and idiosyncracies, the foibles and absurdities, the distortions and aberrations of human life such as no writer before him possessed. And up to this day his art of striking and original characterization, suggestive rather than descriptive, has hardly been surpassed.

How graphic is that scene ${ }^{1}$ from the nursery, satirizing the overfeeding of the children of the rich. "Why is it," he asks, "that so many less children of the rich grow up to a mature age than children of the poor? Because of the excess of feeding rich people indulge in. First the sister makes a jelly for the baby and pushes it into his

1 Loc. cit., i, 433 f. 
mouth. But baby's little stomach cannot hold much and is soon full. So the jelly comes out again; but sister pushes it in again. Then comes auntie; and goes through the same performance. Then comes the nurse and says: "Dear me, baby doesn't eat a thing today," and proceeds to fill it up once more. So baby lies there, screaming and kicking."

What a power of homely parody there is in the grotesque comparison between the locust and the robber knight." "Wherever he goes, he acts like a locust. The locust always wants to sit in the grass where it is thickest. So the robber knight always wants to live on the fat of the land. He scatters the peasants' fodder and hay before his horses, much more of it than they can eat. When one chicken would be enough, he kills ten. What the farmer's family might live on for a whole year, that he would squander on himself in a single day, if he could. And yet, a robber knight seldom comes to look comfortable and portly. Just like the locust, which, however deeply it may eat into the grass, never gets fatter, always is lean and longlegged and gnat-like. So are you, robber knight. And like a locust you come hopping along on your jaded nag, with your shoes dangling from your feet

1 Loc. cit., i, $368 \mathrm{f}$. 
in shreds. And you are never well taken care of and must finally die a shameful death - again like the locust, for it is trodden down by the people or the cattle or cut in pieces by the scythe, when they mow the grass."

And where in all polemic literature is to be found a more powerful invective, a bolder or firmer grasp of reality than in Berthold's thundering words against " usury," that is against any kind of money transactions based on the taking of interest." " $\mathrm{Fi}$, usurer, how do you employ your time? How will you stand at the great reckoning? How much worse you will fare than all other sinners who ever lived or will live. For your time does not only pass uselessly, it passes uselessly and shamefully and sinfully. All other sinners give at least some part of their time to better things; only your time is given to sin day in day out uninterruptedly. See, usurer, ever since I began to preach today, you have kept on getting richer - six pennies may be - by your pawnbroking and money lending. Ye adulterers, sitting here before me, you have not been committing adultery during this time. Ye murderers, you are not committing murder now, you are sitting here properly and well mannered. Ye topers, you are not drinking now, but are keep-

$$
1 \text { Loc. cit., i, } 20 \mathrm{f} \text {; cf. } \mathrm{I} 37 \mathrm{f} \text {. }
$$


ing your thirst in check. Ye robbers, you are here before me without pillaging and burning and other misdoings. Ye swearers and blasphemers, you are sitting here well behaved and are keeping your tongues. And the same you do when you are at mass or at another service. But you, usurer, whatever time it may be, you are never resting from sin. Since I began to talk about you, you have again become richer by half a penny. You make money at mass, at matins, during the sermon, on Christmasday, on Goodfriday, on Easter Sunday, on Whitsunday, whatever God's time it may be. Now see to it, usurer, how you are going to make good to God for his time. Ye devils, on Judgment Day bear me witness that I have reclaimed God's time for him! Ye angels, bear me witness! All ye people, bear me witness!"

In all this we recognize an individual of extraordinary readiness and acuteness of perception, a man of almost startling originality. The democratization of the courtly ideal of personality, of which I spoke before as a concomitant result of the rise of burgherdom and peasantry, is illustrated by this man perhaps more impressively than by any other figure of the thirteenth century. In many respects Berthold is far inferior to the noble characters of the chivalric epoch: he is an intolerant 
zealot, a Jew-baiter, a persecutor of heretics. Of the right of an honest opinion differing from his own he has no conception. And yet, this rough and passionate fanatic is a more modern man than the highly cultivated, well-poised and harmonious men of our courtly literature. With him the chief concern of existence is not any longer a question of aristocratic etiquette, a conflict between courtly custom and personal will and desire. To him the ideal man is not any longer confined to a particular class, be it knighthood or burgherdom. Life in its totality storms in upon him, life with all its sublimity and all its meanness, all its crudity and all its tenderness, with its social claims and its natural instincts, with its delights of heaven and its terrors of hell - and everything leaves an impress upon him, everything he makes a part of himself, everything he transforms in his receptive and vivid imagination into a work of art. If German literary historians of today speak of such a man as a representative of artistic decline setting in with the decay of chivalric literature, they forget that the only standard by which we can safely measure the value of all art is the degree in which a work of the imagination heightens and deepens our sense of life. Measured by this standard, the sermons of Berthold of Regensburg are works of art which 
take their place by the side of the Minnesong of Walther von der Vogelweide and Wolfram's Parzival.

I have tried to sketch the process of the deepening and heightening of personality which is revealed to us in the literature of religious contemplation and in the sermon of the thirteenth century. In mysticism of the fourteenth century this process reaches its climax.

The fundamental thought of the German mystics of the fourteenth century was nothing new. It was a revived and christianized Neo-platonism. Throughout the Middle Ages more subtle thinkers had been fascinated by the neo-platonic conception, that the world is an incessant and gradual differentiation of the originally undivided and undifferentiated Divine; that man, however, and man alone, possesses the power by a free act of will to reverse this incessant process of differentiation, and thus to return from the diaspora of manifold phenomena into the oneness of the undivided Divine. The so-called Dionysius Areopagita, Scotus Erigena, Hugo and Richard of St. Victor, Bernard of Clairvaux - these all see the essential goal of human life in this return from the many into the one; they all love to dwell on the different stages of inner concentration by which man approaches this goal; 
they all praise enthusiastically the state of highest self-surrender where man is completely welded into one with the Divine - as the waterdrop is resolved into wine; or as iron, melting in the fire, seems to become fire, or as the air, illuminated by the sun, seems itself to become sunlight. ${ }^{1}$ It is, however, no exaggeration to say that this ideal of complete selfsurrender of the individual to the infinite has seldom produced such a variety of individual life as in the German mystics of the fourteenth century. Three of the most pronounced personalities produced by this mystic longing for the merging of personality in the Divine I shall try briefly to characterize: Master Eckhart, Heinrich Suso, and Johannes Tauler.

A wonderful solemnity and impressive harmony is spread over the thought of Master Eckhart, the intellectual head of the German mystics. The whole universe, from the highest state of purest spirituality to the lowest worm in the dust, is to him the emanation and revelation of one mighty and eternal will. In its most elemental and fundamental form this will is apparently without willing; it is pure, undifferentiated being, uncreated nature; the naught, that is, the negation of all contrasts;

1 Cf. Bernard of Clairvaux, De diligendo Deo, c. Io; Migne, Patrologia latina, vol. 182, p. 991. 
the synthesis of all life; the godhead by itself. This infinite and unmodified eternal being, tranquil and unmoved, is, however, at the same time the source of all motion and of all the variety of finite beings. It eradiates without losing its substance; as the sun - according to medieval physics - sheds light without losing it. The highest form of this self-manifestation of the godhead is the Trinity, which Eckhart conceives of as a constant process of self-realization of the complexity of the infinite, and as its constantly renewed awakening to full consciousness. In the Son the Father comes to know himself, and Father and Son create out of their common love the Holy Spirit - a strange mythical birth of divine forms going on unceasingly in the highest regions of spiritual existence. To this transcendental process of a continual divine birth the visible world forms a lower counterpart. Into the visible world the Divine is also constantly discharging itself; yes, only.in the fullness of the world, with its countless forms and contrasts, does the Divine find its fullest expression. "All things are God; God is all things. God may not understand himself without me. Before there were creatures, God was not God." 1 These are some of Eckhart's sibyllinic formulas to express the divine-

1 Pfeiffer, Deutsche Mystiker, ii, 31 I, 282, 583, 28 I. 
ness of the world. But by the side of this fact of the divineness of life there stands the other fact of its earthiness. We cannot get away from the tragic conflict pervading all life, the conflict between the naught and the aught, between the infinite and the finite, between spirit streaming from above and matter pressing on from below. And thus, after all, in its scale of forms from the most highly organized beings to inanimate objects, the world presents the spectacle of a gradually diminishing admixture of free spiritual power and a gradually increasing admixture of dead material weight.

Man alone has the faculty of freeing himself from matter, of giving himself fully over to the divine spirit and of thus rising above the conflict which enthralls all creation. "In dumb creation there is something of God, but in the human soul there is God divine. The eye with which I see God is the same eye with which God sees me. My eye and God's eye are one eye." 1 It is only a question of man's becoming fully conscious of his high estate, of his divine nature. "We are to turn the eyes of our reason upon ourselves, and contemplate the nobility of our spiritual being, and recognize that we have been so formed as to be by divine mercy

1 Pfeiffer, loc. cit., 230, 3 I2. 
united to the eternal spirit. And if we thus come to know our own riches, we should find such transcending joy in them that we should care no longer for any outward pleasure and satisfaction." 1 Inwardness, then, is the great goal of life. Through descending into the innermost recesses of the soul, through retiring from the distracting senses into the oneness of the mind, through complete absorption in the spiritual, do we rise above the dualism of life, do we reach the Divine. "When the soul has reached this state, it looses its own self, and God draws it into himself, so that it is entirely absorbed in him, even as the sun draws the morning red into itself so that it is entirely absorbed by light." 2

He who thus has fully entered into the unio mystica with the Divine has become immune against the perils of circumstance and chance; he has freed himself from the blind superstitions of the multitude; he has emancipated himself from the need of ecclesiastical conventions; he has come near the state of human perfection in which the good will be done for its own sake. "The highest that the spirit may attain in this mortal clay is this: to live in such a manner that virtue is no

1 Jostes, Meister Eckhart und seine Jïnger, p. 49.

2 Pfeiffer, loc. cit., p. 491. 


\section{FOURTEENTH CENTURY MYSTICISM 63}

longer an effort, that is, that all virtues have become so natural to the soul that it not only purposely practises virtue, but makes all virtues shine forth from itself unconsciously, even as though it were virtue itself." 1

It is certain that Master Eckhart, the doctor of divinity, Dominican prior at Erfurt, professor of theology at the school of his order at Cologne, would have inwardly revolted against the idea of harboring unorthodox thoughts. Indeed, a short time before his death he publicly denounced such accusations as misunderstandings of his teaching and explicitly accepted the supreme authority of the church. That, however, the principle of his thought was diametrically opposed to orthodox Christianity, that it tended toward the dissolution of the hierarchical system and toward complete religious freedom, would be clear, even if two years after his death the Roman See had not officially condemned the majority of his teachings and thus formally acknowledged their revolutionary character. Eckhart is indeed a forerunner of modern pantheism. His conception of the world as a continual transition of the godhead from naught to aught, from the potential to the actual, from the formless one to the multiform many, is a clear

1 Ztsch.f. hist. Theol., 1864, p. 169. 
anticipation of the Hegelian principle of the selfunfolding of the Idea. His ideal of losing oneself in the abyss of the Divine suggests Goethe's "Weltseele komm! uns zu durchdringen," and "Sich aufzugeben wird Genuss." And his description of the highest state of perfection, in which duty has become an instinct, brings to mind Schiller's ${ }^{1}$ definition of the Beautiful Soul as that state "where the moral sentiment has taken possession of all the emotions to such a degree that it may unhesitatingly commit the guidance of life to the instinct without running the risk of conflicting with its decisions."

If Master Eckhart points toward the great classic German writers of the end of the eighteenth and the beginning of the nineteenth century, his pupil Suso transports us into the emotional world of romanticism. And as the intense subjectivity of the romantic poets has led to a curious oscillation in their works between the two extremes of symbolism and naturalism, so we find these same extremes side by side with each other in the effusions of this medieval monk. Suso belongs to those over-refined, erratic personalities, like Amadeus Hoffmann, Poe, Ibsen, and Hauptmann, who express themselves only in extremes, who rush

1 Sämtl. Schriften, ed. Goedeke, x, 403. 
from the airiest visions to the grossest materialism, who revel now in ecstatic flights of imagination and now in painful reproductions of crass actuality.

In Suso the emotional tension of German mysticism reaches its climax. The whole strife of a time torn by tremendous conflicts seems to vibrate sympathetically in his soul. It seems as though large and wide-reaching popular disturbances the struggle between Empire and Papacy, the revolution of the guilds against the city patriciate, the religious reform movements of the "Friends of God " and similar sects, the horrors of the Great Plague, the cruelties of Jew-baiting, the fanaticism of the Flagellants - as though all this had been crowding in upon the contemplative mind of this solitary monk, setting in motion its innermost chords and calling forth therefrom sounds of dark passion and fierce power and then again of sweetest purity and transcendent beauty.

With what knightly courteousness and grace does he, the scion of a patrician family of Constance, describe the chivalric love-service which he offers to his chosen one, Eternal Wisdom, in his cloister cell. "As in Swabia," thus he narrates in his autobiography, " the young men at New Year

${ }^{1}$ Heinrich Seuse, Deutsche Schriflen herausg. von K. Bihlmeyer, p. $26 \mathrm{f}$. 
ask for a favor from their sweethearts, so he also on New Year's night turned to his love. Before daybreak he stepped in front of the image where the divine mother holds her lovely child, Eternal Wisdom, on her lap and presses it to her bosom, and he knelt down and began to sing a sequence to the mother, praying that she permit him to receive a wreath from her child, and he was so deeply stirred that the hot tears welled forth from his eyes. And then he turned to Eternal Wisdom, bowed down to the ground, and greeted his love, and spake: ' Thou, dearest, art my Easter day, my heart's summer delight, my joyous hour. Thou art the sweetheart whom alone my soul is wooing and craving and for whom it scorns all other loves. Oh, reward me this night, and let me win a wreath from thee." "

He invites Eternal Wisdom as a guest to his table, and offers her bread and fruit. ${ }^{1}$ He sees her in manifold forms. "She hovered," he says, ${ }^{2}$ "high above him on a throne of clouds, she twinkled like the morning star and shone like the sun. Her crown was eternity, her garment was bliss, her mantle all joys' fulfilment. She was far and near, high and low, she was present and yet

1 Loc. cit., p. 24.

2 Loc. cit., p. I4. Cf. Herder's poem "Die ewige Weisheit," Werke, ed. Suphan xxviii, 221. 
hidden. She reached above the highest of the heavens and touched the deepest of the earth's abysses. At one moment she appeared as a beautiful maiden, and then suddenly changed into a proud squire. She inclined herself toward him and greeted him kindly and spake lovingly: Praebe, fili, cor tuum mihi."

All this sounds like an echo of chivalric minnesong. How little, however, these feelings had, after all, to do with courtly love, from what a cruelly harsh and hideous reality these ethereal visions came forth, is proved by the narrative of revolting naturalism in which Suso describes the fearful chastisements by which he tried to subdue his rebellious body." " $\mathrm{He}$ had himself made an undergarment of hair-cloth, and in the garment straps in which there were inserted fifty and a hundred pointed nails, made of brass and filed sharp on the point, and the points of the nails were turned against his flesh. And he made the garment tight and held together in front, in order that the nails should penetrate the flesh, and he made it so high that it came close up to his face. Herein he slept at night. In summer nights, when it was hot and he was tired from walking and ill, or when he had bled himself and lay exhausted and the vermin pestered

1 Loc. cit., p. 39 f. 
him, he would betimes feel as though he were lying in an ant-heap; and would weep and gnash his teeth and say: 'Good God, what kind of death is this! Whom murderers kill or the wild beasts, he is done with it quickly. But I am lying here among this horrible vermin and am dying and yet cannot die." " And with a similar delight in the repellent, with a similarly gruesome naturalism, he makes Christ describe the horrible disfigurements of his body which he suffered when hanging on the cross. ${ }^{1}$ " My right hand was pierced by nails, my left hand was hammered through. My right arm was stretched out of joint, my left arm was drawn out of shape. My right foot was sore with open wounds and my left foot was cruelly mangled. I hung in faintness and exhaustion of all my limbs. The blood was breaking forth from all over my body, making it a gory mass and a horrible sight. I was covered with sores and ulcers."

In the ecstasy of enthusiasm Suso often loses control of himself. He would melt away in rapture when Eternal Wisdom initiates him into the mysteries of the transubstantiation. ${ }^{2}$ Like a medieval Werther, he would embrace the universe with the arms of love when singing in holy mass the Sursum Corda. ${ }^{3}$
1 Loc. cit., p. 210.
Loc. cit., p. 28.
2 Loc. cit., p. 290. 
This same man, however, experiences all the different matter-of-fact episodes of his life with such an intensity and relates these episodes with such a power and precision of actual observation that they impress the modern reader as scenes of present-day life, and often make one hold one's breath from excitement. Some of these scenes stand before us with a truly marvellous distinctness. How a little girl accuses Suso of having stolen a crucifix, and thereby incites a great tumult against him in the town $;{ }^{1}$ how in another village he is accused of having poisoned the wells, and barely escapes death at the hand of the raging mob that has gathered there for the fair; ${ }^{2}$ how his sister runs away from the nunnery, and thereby plunges him into the depths of despair until he succeeds in leading her back to her vow; ${ }^{3}$ how a lewd woman whom he had tried to convert charges him with being the father of her child and succeeds for a time in making his name despised and rejected; ${ }^{4}$ how in a forest on the banks of the Rhine he meets a highwayman and his paramour and is frightened by them out of his wits, ${ }^{5}$ - these and similar happenings are told in a manner reminding one of Zola or Tolstoi.
1 Loc. cit., p. 66.
Loc. cit., pp. II 7 ff.
2 Loc. cit., pp. 74 ff.
5 Loc. cit., pp. $78 \mathrm{ff}$.
${ }^{3}$ Loc. cit., pp. 70 ff. 
No painter of the Cologne school has represented the idyllic bliss of heaven with more delicate and rosy colors than Suso.' "Look upon the beautiful heavenly heath: here summer's delight, here May's festive meadow, here the vale of true bliss. Here you see joyful glances go from love to love; here harping and fiddling; here singing, dancing, and ever rejoicing; here all wishes' fulfilment; here love without sorrow, in everlasting security. Now look upon the countless multitude, how they drink from the welling fountain of living waters; how they gaze upon the clear pure mirror of the godhead in which all things become known to them. Steal still farther forward and look, how the glorious queen of the heavenly land, clad in joy and dignity, hovers above all the heavenly host, how the divine mother of mercy turns her eyes, her mild, merciful eyes, so benignly upon you, how her miraculous beauty gives joy and bliss to the whole heavenly host."

If we contrast with this idyllic vision the fierce, passionate wailings of a dying man whose voice Suso hears calling for help, we are indeed reminded of the contrast between the Ghent altar of the brothers van Eyck and a Last Judgment scene by Breughel.2 "O God in Heaven, why was I born

$$
{ }^{1} \text { Loc. cit., pp. } 24 \mathrm{I} \text { f. } \quad 2 \text { Loc. cit., pp. } 280 \mathrm{ff} \text {. }
$$


into this world? The beginning of my life was crying and weeping, and now my leave-taking is bitter wailing and lamenting. I strike my hands over my head, I wring them feverishly, I turn my glance to all the corners of the world, whether some help or comfort may be found. But it cannot be. I am like a bird that is lying under the claws of a hawk and has lost its senses from fright. My hands begin to wither, my face to grow pallid, my eyes are breaking. Ah, the thrusts of grim death strike my chest! I am heaving heavily, the light of this world grows dim. I am looking into the other world. Great God, what a sight! The gruesome forms of the black Moors are gathering, the hellish beasts have surrounded me, they are lying in wait for my soul. O God, I see the wild raging flames shoot up, hideous monsters pass hither and thither, like sparks in the fire. And thus I depart."

From what has been said it is obvious that the traditional view of Suso as a spiritual minnesinger is far from being adequate. His personality was far too complicated to be a mere reflex or afterglow of the age of chivalric culture. The chords of his soul were so high-strung and vibrated so quickly that the whole fullness of life re-echoed in them. $\mathrm{He}$ and his compeers - for he had many kindred and followers, especially in the convents of South 
Germany - do not point backward to the age of chivalry, they point forward to the great epoch of Flemish and German painting in the fifteenth century. The extraordinary combination of deep religious feeling, of rapturous delight in the mysteries of a divine universe, with minute and often harsh and painful reproduction of the smallest detail of every-day reality which mark fifteenth-century painting from the van Eycks to Dürer, cannot be fully understood without taking into account the intense subjectivity and emotionalism of that phase of the mystic movement which Suso represents.

In Johannes Tauler, the great Strassburg preacher, German mysticism of the fourteenth century reaches its fullest popular influence and its sanest and most rational form. Of all mystics, Tauler is the least eccentric; more earnestly than either Eckhart or Suso does he strive for a reconciliation between the absorption of the individual by the Divine and the duties of the individual toward society.

For Tauler, as for his teacher Eckhart, man is originally a part of the godhead. Like Eckhart, he laments the alienation of man from his origin and sees the goal of man in his return to it. But he is less abstruse than Eckhart; he does not revel so much in contemplation of the " formless and shape- 
less abyss" of the infinite; he lays more emphasis on the striving of man for perfection. In the analysis of the various stages which shall lead man to this perfection, Tauler shows affinity with Suso. But he is separated from Suso by his clearer sense of the attainable, his soberer view of human limitations. With all his predilection for asceticism and renunciation of the world, he is without a trace of fanaticism.

He openly protests against the morbid exaggerations of monkish discipline; he preaches self-control, not self-elimination. In the fine comparison of the human soul with the vine, he represents human nature as an essentially sound and hardy plant whose growth is to be furthered by rational pruning and must not be stunted by senseless mutilation. He asserts that a life of honest labor and faithful fulfilment of every-day tasks is more pleasing to God than eccentric revelling in high inspirations." "Many a man is busy in the world and works for his wife and children, and many a man sits in his shop and makes shoes to get a living, and some poor people go from village to village to earn their bread with great trouble; and, I tell you, all these may fare a hundred times better before God than some would-be prophets." "I know one

1 Die Predigten Taulers, ed. by F. Vetter, in: Deutsche Texte des Mittelalters, xi, 179. 
of the greatest Friends of God, who all his life has been a farmer and is so now. And he once asked the Lord whether he should give up farming and sit in church. And the Lord said, 'No, he should rather go on earning his bread by the sweat of his brow; that was the best service he could give to Him.' " Tauler, then, believes in the divine origin and the divine mission of every calling and every kind of activity; with truly democratic conviction he praises work as the truest title to nobility; in the right conception of work he sees the way to social peace. " One can spin, another can make shoes, and some have great aptness for all sorts of business, so that they can earn a great deal, while others are altogether without this quickness. These are all gifts proceeding from the Spirit of God. If I were not a priest, but were a member of a guild, I should take it as a great favor that I knew how to make shoes, and should try to make them better than any one else, and would gladly earn my bread by the labor of my hands. So let every one see to his appointed office, and all work thereby for the common good."

In all this there is revealed an individualist in the best sense, a man who, standing in the midst of life, has an open mind for the needs and the duties of all classes and of each individual, and who has before

1 Ed. Vetter, loc. cit., p. 177 . 
his eye the ideal of a democratic society resting upon the mutual acceptance and free co-operation of each and all. The fullest significance, however, of Tauler's individualism comes to light in his utterances on the last and highest questions, on the relation of the individual to God. None of the mystics has conceived of the unio mystica, the sinking of deified man in the infinite, in so genuinely human a manner, or in terms so far raised above all exclusively ecclesiastical views. With what a deep, manly earnestness does he oppose to external conventional churchliness the inner selfscrutiny and self-discipline of the individual. ${ }^{1}$ "Behold, dear friend, if thou shouldst spend all thy years in running from church to church, thou must look for and receive help from within, or thou wilt never come to any good; however thou mayest seek and inquire, thou must also be willing to be tormented without succor from the outward help of any creature. I tell you, children, that the very holiest man I ever saw in outward conduct and inward life had never heard more than five sermons in all his days. Let the common people run about and hear all they can, that they may not fall into despair or unbelief; but know that all who would be God's, inwardly and outwardly, turn to

$$
1 \text { Loc. cit., p. } 213 .
$$


themselves and retire within." With what a glow of sacred conviction does he describe the necessity of ever deeper scrutiny, ever higher striving, ever purer knowledge, ever freer and fuller surrender, until at last man, without the interposition of any external institution, finds himself indissolubly welded into one with the Divine." "And if such a man were dragged into the bottom of hell, then there would be the kingdom of God and eternal bliss in hell." And what a truly grand exaltation, what a wonderful vision of human possibilities, is there in the picture which Tauler draws of this state of ideal humanity. "When through all manner of exercises, the outward man has been converted into the inward, spiritual man, and thus the two, that is to say, the powers of the senses and the powers of the reason, are gathered up into the very centre of the man's being, - the unseen depths of his spirit, wherein lies the image of God, - and thus he flings himself into the divine abyss in which he dwelt eternally before he was created, then, when God finds the man thus simply and nakedly turned towards him, the godhead bends down and descends into the depths of the pure, waiting soul, and transforms the created soul, drawing it up into the uncreated essence, so that the spirit becomes
1 Loc. cit., p. 33.
2 Loc. cit., p. 363 . 
one with him. Could such a man behold himself, he would see himself so noble that he would fancy himself God, and see himself a thousand times nobler than he is in himself, and would perceive all the thoughts and purposes, words and works, and have all the knowledge of all men that ever were."

Here, we may say, the individualistic tendency of medieval German mysticism has reached its consummation. Here the conception of personality has been heightened and deepened to such an extent that it seems impossible to heighten and deepen it further.

Surely, whatever formulas have been employed since Tauler's time to define the ideal of human existence - the glorification of reason by the Humanists, Luther's exaltation of faith, Rousseau's gospel of nature, Goethe's and Schiller's apotheosis of culture, Nietzsche's proclamation of the Superman - they are nothing but ever new attempts at re-stating in new terms what Tauler felt to be the fundamental need of life: the need of man's being at one with himself, if he is to conquer the infinite. 


\section{CHAPTER III}

POPULAR SONG AND POPULAR SATIRE FROM THE THIRTEENTH TO THE SIXTEENTH

\section{CENTURIES}

7 HERE seems to be little in common between

1 mysticism and folksong. And yet, it is not an accident that the fourteenth century, which witnessed the climax of German mystic thought, also witnessed the first great outburst of German popular song. It is not an accident that during the same decades when the disciples of Suso and Tauler in monastic seclusion would penetrate into the depths of the divine and search for selfhood in the infinite, the Limburg Chronicle should have been able to relate from year to year:" "At this time they whistled and sang in the lands near the Rhine and the Main in village streets and on country roads this or that or such and such a song." In a different manner from mysticism but for all that no less audibly than mysticism, does the popular song, from the fourteenth century to the sixteenth proclaim the important historic process which forms the principal note of the whole epoch of bur-

1 Limburger Chronik ed. A. Wyss, pp. 56, 65, 70, 74, 75. 
gher ascendancy: the heightening of individuality, the deepening of the inner life, the democratization of personality.

From the days of Herder's "Von deutscher Art und Kunst " to Professor Gummere's " The Beginnings of Poetry "it has been asserted over and over again that popular song is not the product and property of an individual, but is produced and owned by the whole people. This assertion contains an important truth. A new song, whoever be its author, is taken up by the multitude; it is sung by so many different persons, in so many different ways, on so many different occasions, that in the course of time, through additions, omissions, and transformations, it may lose its original character and become as it were something impersonal. It is moulded, so to speak, by the stream of public imagination, as the pebbles in the brook are moulded and remoulded by the current of the water which carries them along. This also is unquestionably true - as Professor Bücher has shown in his admirable "Arbeit und Rhythmus" - that a large part of popular song originally was a rhythmic accompaniment to the common activity of groups of people, be it manual labor or religious rites or communal festivities, and, in so far as this was the case, did express not so much the feelings of an individual as 
of groups of individuals, and was therefore, from its very start, in essence as well as in form anonymous. But all this cannot alter the fact that the German folksong of the end of the Middle Ages, if we wish to determine its peculiar place in the development of German culture, must be regarded as a most impressive, collective testimony to an extraordinary heightening of personal sensibility and personal power of imagination, among masses of people.

The very manner in which the anonymity of these songs is constantly encroached upon by subjective allusions, makes us at the outset divine the personal experience, the individual situation from which each song has sprung. In many cases, the very first line indicates the subjective character of the whole by introducing an I, Thou, We, or You: "I heard a sickle rustling "- "I know a sweet brown lassie " - " I stood of an early morning " "I rode with cheer through a forest " - "Thou rider gallant and noble" - "What shall we now be a-doing " - "Come on, ye boon companions" - similar uses of the first or second personal pronoun in the opening line of a folksong might easily be multiplied. The last stanza frequently begins with the question: "Who is it that sang us this ditty?" and in the answer to this question the 
author, if he does not openly give his name, likes at least to designate his occupation and station in life. The answers are varied enough: "a landsknecht free" - "three landsknechts good at Magdeburg town" - "a sturdy boy from Switzerland" - "a journeyman" - "a baker's apprentice" — " a butcher's son" - "a simple peasant" - "a miner" — "a rider brave" - "two riders brave, an old and a young one" - "a scribe" - "a student" — "a fisherman" — "a pilgrim" — "a poor beggar" - "three maidens at Vienna." Occasionally we hear a frank expression of the author's satisfaction with himself and his production:

Wer ist, der uns das liedlein sang

Aus freiem mut, ja mut?

Das tet eins reichen bauren son,

War gar ein junges blut. ${ }^{2}$

And at times the author cannot resist the temptation of telling his hearers of some personal experience from his own life which has either no connection at all or only a slight one with the subject of this particular song:

Der uns disz neuwe liedlein sang,

Er hats gar wohl gesungen;

Er ist dreimal in Frankreich gewest

Und allzeit wieder kummen. ${ }^{1}$

1 Erk und Boehme, Deutscher Liederhort, ii, 260.

2 Loc. cit., i, 47 r. 
In short, the personality of the author, his class, his calling, his experiences, present themselves to us in many of these songs clearly and palpably, one might say: without, if not contrary to, the intention of the author himself.

And now the subject matter and the form of these songs. There is hardly a side of human character, hardly a phase of human life, hardly an event in national history, which did not find expression in them. It is as though the circulation of the national body had been quickened and its sensibilities heightened; as though people were seeing with keener eyes and listening with more receptive ears; as though they were gathering more intently the thousandfold impressions of the inner and the outer world: of stars and clouds, of trees and brooks, of love and longing, of crime and revenge, of broken faith and heroic deeds; and as though all these impressions were condensed into a living form, an artistic image, a personal creation, in popular song.

The folksong of the fourteenth, fifteenth, and sixteenth centuries is not only a worthy successor of the chivalric Minnesong, but it is also its enlargement and fulfilment. It surpasses the chivalric Minnesong in range of subjects, in depth of feeling, in human sympathy, in power of presentation. While courtly lyric even in its best representatives 
remains the expression of class consciousness, however refined and cultivated this consciousness may be, the folksong of the end of the Middle Ages is universal. It is folksong not in the sense that it expressed only the feelings of the common folk; it addresses itself to high and low, poor and rich, learned and unlearned. Like the sermon and the mystery plays of the fifteenth century, like the Gothic cathedrals with the popular language of their altar pieces and portal sculptures, the folksong of that period also was a spiritual bond embracing all classes and ranks of the people. Oldest saga and most recent event, public affairs and the secrets of the heart, longing for eternity and enjoyment of the moment, tenderest love and frivolous banter, jubilant exultation and nameless woe, romantic adventure and wedlock commonplace, robber-knight arrogance and peasant pride, journeymen's wanderings and guild traditions, childish play and Last Judgment terror - whatever stirred the life of those times, it all found a direct and artless response in popular song.

In refinement of form the folksong, for the most part, is inferior to the lyrics of chivalry. It has something bourgeois-like, homely, and unpretentious. If Walther von der Vogelweide reminds us of the grace and delicacy of the sculptures of 
Strassburg and Bamberg cathedrals, the folksong frequently suggests the bluffness and angularity of a relief by Adam Kraft. The suddenness of its transitions, the fragmentariness and abruptness of its presentation - which appealed so much to Herder and the romanticists - often leads to obscurity and ambiguousness. Side by side with traits of supreme beauty and entrancing charm it shows at times features of gross, repellent vulgarity; just as in Flemish painting of the fifteenth century. enchanting naiveté and grace of expression is so often found side by side with harshness and commonness of form. But what do all these formal defects count compared with the one fact that the folksong breaks forth from the personal experience, directly and without circumlocution, and thereby brings to view reality - both inner and outer - in all its freshness, with all its contrasts, all its paradoxes, all its mysteries and riddles. Every genuine folksong is born from the moment; it is a piece of nature; it is a sound produced by the mighty whir of the world in an individual soul, which, reverberating in other souls, echoes the common feeling of life.

The mass of chivalric Minnesong, as we have seen, was dominated by society convention; only in a few exceptional personalities the feeling of 
genuine humanity rang out. A similar danger threatened the folksong of the end of the Middle Ages: its bulk shows the deteriorating influence exerted by the crowd; only the minority of these songs is unaffected by the trivial, the sensational, the commonplace. But if we compare the best of the folksong with the best of the Minnesong, we must admit the folksong leads us into a freer, wider, and essentially sounder world. We may transport ourselves back into the conceptions of Walther von der Vogelweide, we may enjoy his images of life, we may sympathize with his ideals. But the folksong we experience directly in ourselves; we feel our kinship with it; we are not separated from it by social barriers or historical traditions. "Hier bin ich Mensch, hier darf ich's sein."

From the great wealth of the popular love song, with its manifold expressions of parting and longing, of wooing and grieving, of rejoicing and mourning and faithfulness unto death, I select four short songs which seem to me particularly well adapted to make us feel the nobly simple, universally human keynote of this love poetry.

What is all the fastidious and laborious landscape painting of the courtly Minnesong compared with the mute expression of instinctive affinity be- 
tween man and nature contained in the touching words of the lonely lover who makes the linden tree the confidant of his sadness:

Es stet ein lind in diesem tal, Ach gott, was tut sie da? Sie will mir helfen trauren, Dass ich kein bulen hab. ${ }^{1}$

And still more clearly does this affinity express itself in the next stanza in which the youth comforts both himself and the linden tree:

So traur, du feines lindelein, Und traur das jahr allein!

Hat mir ein brauns meidlein verheiszen, Sie wöll mein eigen sein -

Only a year it will last; then both the youth and the linden tree will be able to rejoice. For then he will have his sweetheart for his own; and he knows, the tree will be glad for him.

What are all the romantic adventures of chivalric poetry compared with the deep tragedy of the two short stanzas which tell us of the fate of the miller's apprentice and his love. She lives yonder on the hill where the mill wheel is turning; and when he looks up to it from the valley, then his senses are bewildered, and it seems to him as though the

1 Erk und Boehme, loc. cit., ii, 217. 
ceaseless turning of the wheel and the ceaseless flowing of the water were his own unending love:

Dort hoch auf jenem berge

Da geht ein mülerad,

Das malet nichts denn liebe

Die nacht bis an den tag. ${ }^{1}$

This is the first scene; but without transition, sharp and cruel as life itself, and yet not without that strength of feeling and inner poise which a healthy man preserves even in the breakdown of his happiness, there follows the picture of the catastrophe:

Die müle ist zerbrochen,

Die liebe hat ein end.

So gsegn dich got, mein feines lieb!

Jez far ich ins ellend.

How artless and enchanting, how dreamy and yet how distinctly drawn is the scene in the wheatfield where two reaping girls, swinging the scythe in even measure, give way to such contrasting feelings. The one bewails the loss of her sweetheart, the other rejoices in her own happiness of newly awakened love. And grief and joy appear united and, as it were, borne along by the rhythmic rustling of the scythes under which the blades of grain are falling:

1 Loc. cit., ii, 234. 
Ich hort ein sichellin rauschen, Wol rauschen durch das korn, Ich hort ein feine magt klagen, Sie het ir lieb verlorn.

" $L a$ rauschen, lieb, la rauschen, Ich acht nit, wie es ge:

Ich hab mir ein bulen erworben In feiel und grünen kle."

" Hast du ein bulen erworben In feiel und grünen kle:

So ste ich hie alleine

Tut meinem herzen we." 1

And finally, how touchingly simple, how devoid of all morbid exaggeration is the farewell of the journeyman from Innsbruck where he leaves his love at home. He knows, foreign lands cannot offer him any joy. But he cheers himself by the thought of her; her heart will be his home wherever he goes; hers he will be forever; and he asks God to preserve her until his return. Of the tune of this song Sebastian Bach is reported to have said: he would gladly give his best compositions for this one melody.

Innsbruck, ich muss dich lassen,

Ich fahr dahin mein strassen

In fremde land dahin.

Mein freud ist mir genommen,

Die ich nit weisz bekommen,

Wo ich in elend bin.

1 Loc. cit., ii, 472. 
Grosz leid musz ich ertragen, Das ich allein tu klagen

Dem liebsten buhlen mein. Ach lieb, nun lasz mich armen

Im herzen dein erwarmen, Dasz ich musz dannen sein.

Mein trost ob allen weiben, Dein tu ich ewig bleiben, Stet, treu, der ehren frumm. Nun musz dich gott bewahren, In aller tugend sparen, Bis dasz ich wieder kumm. ${ }^{1}$

It is hard to think of poetry more delicate and more appealing, more universally human and more specifically personal than these and similar love songs. Carried along by melodies which set the innermost chords of the soul in vibration, these songs have outlasted all the vicissitudes of German history of the last five hundred years; they have outlived the distress of the Thirty Years' War and the times of princely tyranny and scholastic pedantry; they have comforted the common people and have inspired the great poets and composers of the eighteenth century; and through the romanticism of the nineteenth century they have finally become a fountain of youth for German lyric poetry at large.

1 Loc. cit., ii, 546. 
I must pass over historical popular lyrics, although here too individuality asserts itself not infrequently with characteristically German ruggedness, in order to analyze a few at least of the most representative popular ballads. In the ballad the folksong of the fourteenth to the sixteenth centuries reached its climax; and here again it is the firm grasp, the bold stroke - to use a word of Goethe's, - the absence of all laborious description, the limitation to a few striking features, the clever use of dramatic contrasts, the suggestiveness of characterization, the irrepressible onward striding from peak to peak, as it were, of the narrative - in a word, it is the intense personal concentration and power which more than anything else determines the peculiar character of this poetry. Poems of supreme beauty and truthfulness have come forth from this intensity and concentration of personal feeling in the popular ballad, poems which again make us wonder how critics ever could have spoken disparagingly of the end of the Middle Ages as a period of literary decline.

One might indeed say: one such ballad as the ballad of the "Two Royal Children " - the German version of the Greek legend of Hero and Leander - outweighs thousands of verses from the epic cycles of chivalry. Not a stanza in this 
ballad which does not enrich and deepen the action; none which does not add a new touching trait.

Et wassen twe künigeskinner,

De hadden enander so lef,

De konnen to nanner nich kummen,

Dat water was vil to bred. ${ }^{1}$

This is the overture. Now two short stanzas which relate the lighting of the candles, their being put out by the "evil nun," and the drowning of the royal youth. And from here on the whole power of poetic beauty is concentrated upon the grief of the bereaved maiden.

Et was up en sunndage morgen,

De lüde wören alle so fro,

Nich so des küniges dochter,

De augen de seten er to.

"O moder," sede se, "moder!

Mine augen dod mi der so we;

Mag ick der nich gon spazeren

An de kant von de ruskende se?"

The mother, apparently foreboding the coming catastrophe, is not willing to allow her daughter to go alone: she must call her youngest sister to go with her. But the daughter insists, that her sister is too childish, she would pick all the flowers on the seashore, and then people would say, she herself had

$$
1 \text { Loc. cit., i, } 296 .
$$


done it. No, she must go alone; her eyes feel so sore. The mother answers: "Then call your youngest brother to go with you." But again the daughter has an excuse: her brother is too childish, he would shoot all the birds on the seashore, and then people would say, she herself had done it. No she must go alone. And now she cannot dissemble any longer: not her eyes are sore, but her heart; not a walk she wants to take, she wants to pray by the surging sea.

"O moder," sede se, " moder!

Min herte dod mi der so we.

Lot annere gon tor kerken, Ick bed an de ruskende se."

And so she puts on her golden crown and her diamond ring and goes up and down on the strand until she finds a fisherman. She hires the fisherman to sink his net in the sea: "fish for me the royal youth."

He sette sin netkes to water,

De lotkes sünken to grund.

He fiskde und fiskde so lange,

De künigsson wurde sin fund.

Do nam de küniges dochter

Von hoefd ere goldene kron:

"Süh do, woledele fisker!

Dat is ju verdende lon!" 
Se trock von eren finger

Den rink von demanten so schon:

"Süh do, woledele fisker!

Dat is ju verdende lon."

Se nam in ere blanke arme

Den künigsson, o we!

Se sprank mit em in de wellen:

" $O$ vader un moder, ade!"

Still more dramatic and impassioned, if not of the same unspeakably touching and pathetic charm as this ballad of the "Two Royal Children," is the ballad of Tannhäuser, a poem containing in brief compass all the essential elements of Richard Wagner's stirring composition. Boldly and effectively this ballad transports us at once into the sultry atmosphere of the Venus mountain, into the conflict between the knight, who longs to free himself from the fetters of sensuality, and the enchantress who wishes to hold him.

" Herr Danhauser, ir seind mir lieb

Daran sölt ir gedenken!

Ir habt mir einen aid geschworn

Ir wölt von mir nit wenken."

"Fraw Venus! Das enhab ich nit, Ich will das widersprechen, Und redt das jemants mer denn ir, Gott helf mirs an ihm rechen!" 1

${ }^{1}$ Loc. cit., i, 39. 
Thus the dialogue swells on: upon the one hand, ever more passionate caressing, ever more urgent wooing; upon the other, ever more violent struggling to get loose, ever more desperate wrenching away, up to the last wild outcry of Tannhäuser:

"Fraw Venus, edle fraw so zart, Ir seind ain teufelinne!"

and:

"Maria, můter, raine maid, Nun hilf mir von den weiben!"

The pilgrimage to Rome, which presently follows, is brought out with the same incisive intensity. First Tannhäuser's readiness for repentance and his trust in God's mercy:

"Ach bapst, lieber herre mein!

Ich klag euch hie mein sünde,

Die ich mein tag begangen hab,

Als ich euch will verkünden.

Ich bin gewesen auch ain jahr

Bei Venus, ainer frawen,

Nun wolt ich beicht und busz empfahn

Ob ich möcht gott anschauen."

With Tannhäuser's craving for penance and absolution there is contrasted the cold and harsh selfrighteousness of the Pope which knows nothing of sympathy with the repentant sinner. The Vicar of Christ does not even enter upon Tannhäuser's 
confession, his only word is damnation, made doubly impressive by the reference to his pontifical staff: as little as this staff will sprout into leaf, so little will Tannhäuser be saved.

Now there follow with flashlike rapidity Tannhäuser's relapse into sensuality, his return into the Venus mountain, and the jubilant words with which he is received by his paramour:

Da zoch er widrumb aus der statt In jammer und in laide:

"Maria, můter, raine maid!

Ich muss mich von dir schaiden."

Er zoch nun widrumb in den berg

Und ewiklich on ende:

"Ich will zu meiner frawen zart,

Wa mich gott will hinsenden."

"Seind gottwillkomen, Danhauser! Ich hab eur lang emboren;

Seind willkom, mein lieber herr, $\mathrm{Zu}$ ainem bulen auserkoren!"

And finally, the harmonious issue of the whole, a glorification of genuine humanity and a condemnation of heartless intolerance: the staff of the Pope bursts into leaf - God has received the sinner into His grace.

Truly, we understand why this ballad, embracing, in its intenseness of personal experience, the 
heights and the depths of life, should have wrung from the most intensely subjective of modern German poets words of boundless admiration. When Heinrich Heine discovered it in a miscellaneous volume of the seventeenth century, he felt, he says, ${ }^{1}$ as though in a dark mountain cleft he had suddenly come across a large vein of gold. "The bold and simple, primitively grand words shone at me so lustrously that my heart was almost blinded by the unexpected brilliancy. I at once felt, from this poem there spoke to me a familiar voice of joy. This poem is like a battle of love, and the reddest heart blood flows therein."

By many further examples it might be shown how sharply the popular ballad individualizes, how fearlessly it likes to bring out contrasts, what bold situations it dares to portray, with what sure hand it works up to a climax. Only two poems, belonging to the favorite cycle of subjects relating to domestic tragedies, may be singled out to illustrate this peculiarity of the ballad still more fully: the poem of the bad mother who has poisoned her stepchild, and the poem of the faithful sister who rescues her brother from the gallows.

The crime of the stepmother is revealed to us in seven short stanzas, each of them consisting of a

${ }^{1}$ Werke, ed. Karpeles, v, 365 . 
brief question and answer directed to and given by the boy. He comes from his aunt's house where the poison has been given to him. He is already in the agonies of death. Every answer of his ends with a "Wie weh ist mir"; every new answer makes us more clearly see how the crime has been perpetrated; and the last answer with its blunt curse unmasks the murderess herself.

Kind, wo bist du hin gewesen ?

Kind, sage dus mir.

"Nach meiner mutter schwester,

Wie we ist mir!"

Kind, was gaben sie dir zu essen?

Kind, sage dus mir.

"Eine brüe mit pfeffer,

Wie we ist mir!"

Kind, was gaben sie dir zu trinken?

Kind, sage dus mir.

"Ein glas mit rotem weine,

Wie we ist mir!"

Kind, was gaben sie den hunden ?

Kind, sage dus mir.

"Eine brüe mit pfeffer,

Wie we ist mir!"

Kind, was machten denn die hunde ?

Kind, sage dus mir!

"Sie sturben zur selben stunde,

Wie we ist mir!" 
Kind, was soll dein vater haben ?

Kind, sage dus mir!

"Einen stul in dem himmel,

Wie we ist mir!"

Kind, was soll deine mutter haben ?

Kind, sage dus mir!

"Einen stul in der hölle,

Wie we ist mir!"1

In the ballad of the "Faithful Sister" also there is an almost breathless suspense. Here also the single parts of the action follow each other stroke upon stroke. Here also each part appears like a flash from the dark, and disappears equally quickly. Here also everything points toward one grand climax. The father, at a drinking bout, has gambled away his only little son to a company of wild fellows. The boy is to be hung by them. The riders come to get him, but none of them dares to lead him out. Then the unnatural father himself seizes him and leads him out of the yard. And now the poem continues:

Wie weit schritt ihm die mutter nach ?

Sie schritt bis hinter die pforte nach.

Wie weit schritt ihm die schwester nach?

Sie schritt bis hinter das galgengericht.

"Ach herren, edle herren mein, Gebt mir mein einziges brüderlein."

${ }_{1}$ Erk und Boehme i, 581. Cf. Child, English and Scottish Ballads i, 153 . 
" Und deinen bruder den kriegst du nicht, Er musz jetzt hangen am galgengericht;

Und wenn du dich ziehst nackend aus Und dreimal um den galgen laufst" -

Und wie das letzte wort geschah, Die kleider schon alle unten war'n.

Und wie sie's erste mal 'rum kam, $\mathrm{Da}$ fingen alle frauen zu weinen an.

Und wie sie's zweite mal 'rum kam, $\mathrm{Da}$ fingen alle herren $z \mathrm{u}$ weinen an.

Und wie sie's letzte mal 'rum kam, Da hieszen sie sie stille stahn:

"Schliesst ab, schliesst ab das kettenband, Und lasst den knaben wieder ins land."1

I trust, it has now become clear that what so often has been praised - and justly so - as one of the most characteristic and greatest beauties of popular song, its extraordinary objectivity, is in reality the result of an extraordinarily heightened subjectivity. The poet of the popular song sees the objects that surround him so sharply, because he himself is a sharply individualized personality. He grasps life in its totality, because in himself life pulsates fully. He has an eye and an ear for the highest and the lowest, for the most delicate and

1 Erk und Boehme, loc. cit., i, 566. 
the grossest of the outer world, because the contrasts of existence clash in his own innermost soul. It is not a mere coincidence that many of the most lustrous figures of popular song belong to the same time which, in the paintings of a Jan van Eyck or a Rogier van der Weyden, has left us portraits of individuals of such a depth of expression, such a firmness of character, such a complexity of will and intellect as hardly any other time has produced. Both painting and folksong of the fifteenth century prove to us that it was the concentration of the inner self which enabled the men of that time to assimilate the world and to reproduce it in art.

If the folksong of the end of the Middle Ages is a popular successor to chivalric Minnesong, we may see a popular successor to the chivalric epic in the satirical narrative from the thirteenth to the sixteenth centuries. German satirical narrative of those times has produced no character which reaches the level of the great characters of the chivalric epic, or which in any sense is worthy to be placed by the side of that immortal parody of the chivalric epic, Cervantes' "Don Quixote." Its subjects offer no room for the portrayal of the highest and deepest that moves the heart of man. Its aims are confined to the problems of a particular time and have no universal application. Moreover, the 
centrifugal development of Germany in those centuries brings it about that the literary representation of reality contained in the satirical narrative bears essentially a local and provincial stamp and reveals hardly anything of that hardy feeling of national power and that joyous lustre of national greatness which make Chaucer's "Canterbury Tales" such a shining monument of English life of the late Middle Ages. And lastly, in artistic form, this satire shows retrogression rather than progress from the thirteenth century to the sixteenth. The Low German animal epic of "Reinke de Vos" is the only satire of the fifteenth century which, as a work of art, could be compared with the earlier satires of the thirteenth century; and "Reinke de Vos" is after all only a copy of the thirteenth century Reinaert by a Flemish poet.

All this must be admitted. But the fact remains that German satirical narrative, no less than the folksong, is an important historical evidence of the individualistic trend of German life from the thirteenth century on. Its wealth of caricature; its richness in strongly, if grotesquely, drawn personalities; its unsparing naturalism; even its revelling in the trivial and the vulgar bring out with particular emphasis the bourgeois character of this period. The protest of the masses against 
the corruption of the nobility and clergy, which in the Reformation of the sixteenth century led to a reversal of the whole social order, is heard in this narrative literature for the first time with popular force. And it is not amiss to compare the part played by this literature in bringing about the social reversal of the sixteenth century with the part played by the novel of the eighteenth century in bringing about the French Revolution. The reading public of Fielding and Le Sage had become weary of the elegant cavaliers and crowned potentates, the aristocratic shepherds, and the learned allegories of pseudo-classic literature. They wanted to see men and women of their own flesh and blood; they wanted to have a representation of actual society with all its distortions and aberrations and with all its need for reform; and this widely-spread desire contributed to preparing the ground for the declaration of the rights of man and the final overthrow of absolutism. Just so in the fourteenth and fifteenth centuries, the ideal and heroic figures of a Siegfried, a Parzival, a Tristan and similar representatives of an aristocratic past had lost their charm for the masses, or survived only in the coarser form of the chapbooks. What people wanted to see in literature was their own life, their own narrow and crowded streets, their 
own gabled houses and steepled cathedrals, their own sturdy and homely faces; and the gratification of this popular desire by the writers of satirical narrative helped on its part to bring on the great democratic upheaval of the sixteenth century.

I must confine myself here to a brief analysis of two of the earliest of these satirical narratives, both belonging to the middle of the thirteenth century, the one a good-natured ridicule of the credulity and superstition of the general public, the other a poignant arraignment of the viciousness of a degenerate robber-knighthood: the collection of humorous tales having for its principal character the astute clerical swindler Amis, and the tragic story of young Helmbrecht, the farmer's son who wanted to be a baron.

The account of the tricks performed by the ecclesiastical mountebank, Amis, is entirely devoid of polemic animosity. At the end the jolly rogue even reforms; he donates the riches accumulated by his swindles to a convent, is himself chosen abbot, and by an exemplary administration of his office wins for himself a title to eternal life. But that these amusing tales as a whole are nevertheless a striking satire upon the church and upon social respectability, is evident. There is hardly a class of people which did not fall a prey to the deceptions of the 
crafty priest. At a church festival he represents himself as having been sent out by St. Brandan to undertake collections for a cathedral, with the provision to accept gifts only from women who have not sinned against their marriage vows. Of course, he is showered with money and valuables by all married women, especially those who feel themselves guilty of unfaithfulness to their marital pledge. ${ }^{1}$ At the court of the king of France he introduces himself as a painter and announces an exhibition of his pictures. These pictures, however, he declares, can be seen only by people of legitimate birth. Of course, there are no pictures at all; but everybody comes, everybody pretends to see the pictures, and Amis pockets large sums of money from the would-be patrons of his art. ${ }^{2}$ One of the most amusing episodes is the trick played by him upon the prior of a rich monastery. ${ }^{3}$ Amis presents himself to the prior as a simple peasant, ignorant of reading or writing, and in his humble way caring only for the salvation of his soul. His appearance of integrity, however, induces the prior to appoint him treasurer of the monastery; and Amis, although he affects great distrust in his capacity to fill this office, discharges it with such

1 Deutsche Klassiker des Mittelalters, xii, 3 I ff.

${ }^{2}$ Loc. cit., 36 ff. $\quad 3$ Loc. cit., 63 ff. 
dexterity that he wins the favor and the confidence of the whole convent. One day he takes the prior apart and tells him under the seal of secrecy that a miracle has happened to him - an angel has appeared before him and summoned him to conduct mass. But how could he, an ignorant, illiterate layman, who has never even looked into a book, read Latin? And yet he would like to make the trial, that is if the prior would be alone with him in the church and assist him. The prior enters upon this plan joyfully. They lock themselves up in the church. Amis is put into priestly garments, he steps before the altar, and lo and behold! he reads the mass from beginning to end most fluently and impressively. The prior is amazed and overjoyed: he has discovered a saint! He spreads his fame abroad; from all parts of the country people flock to the monastery, bringing large offerings of silver and gold to the miraculous man. One fine morning the saintly treasurer is gone, and the silver and gold with him.

Far more bitter and cutting than in these merry tales of the priest Amis is the satire of the other book which I mentioned before, the "FarmerHelmbrecht" by the Bavarian friar Wernher, ${ }^{1}$ a book which in its fierce denunciation of cavalier arro-

${ }_{1}$ Deuische Klassiker des Millelalters, xii, I3 I ff. 
gance and viciousness brings before us something of that elemental wrath and indignation of the oppressed which in the sixteenth century was to lead to the terrible explosion of the Peasants' Revolt. The tragic theme of the conflict between the old and the young, between the honest respectability of the generation of the fathers and the unbridled license of the generation of the sons, has hardly ever been treated more pointedly and incisively than in this little masterpiece which indeed seems an anticipation of the art of Heinrich von Kleist, Turgenjeff, and Gerhart Hauptmann.

How vividly does young Helmbrecht stand before us from the start - this fashionable braggart, this dandified farmer's son and would-be knight, with his blond locks falling over his shoulders, with his beautiful silk cap embroidered with doves, parrots and other designs, with his fine linen, with his doublet of mail and his sword, with his blue surcoat and silver-buckled belt, with the bells on his sleeves which tinkle in the ears of the girls when he dances with them: all these, gifts from his mother and sister who are infatuated with the haughty, spoiled good-for-nothing. And in contrast with him the honest old father, whose whole pride consists in tilling his land with his own hand and in preserving inviolate the simple traditions of his class, who likes 
to remember the time when as a boy he would be sent with cheese and eggs to the baronial castle and could then observe the courtly bearing and the refined manners of the lords and ladies, whereas now the castles resound only with wild carousings and savage atrocities. What gives true greatness to the conflict of this sturdy representative of ancient custom and moral discipline with youthful dissipation and depravity is the inexorable consistency with which the fate of the young degenerate fulfills itself, and the unbending righteousness with which the father, though broken hearted, makes himself an instrument of the divine judgment that overtakes his son.

It is in five stages that the tragic fate of the farmer's family - for through the son's wickedness the whole family is plunged into ruin - is enacted before us.

First the departure of the young headstrong from the old homestead. Movingly the father exhorts him, impressively he depicts to him the blessing and the joys of the farmer's life and the dangers and vices of robber-knighthood; but the son has only words of scorn for the miserable existence of a clod-hopper, and the paternal warnings are as tiresome to him as a lenten sermon. ${ }^{1}$

1 Verses 259 ff. 
"Silence, dear father. Never shall your sacks graze my shoulders; never will I load your waggon with dung; that would ill suit my beautiful coat and embroidered cap. I must taste court life. Shall I drag on three years with a foal or an ox, when I may every day have my booty ? I will help myself to strangers' cattle and drag the peasants by their hair through the hedges. Hasten, father, I will not remain with you any longer." So the father must let him depart. Thirty bolts of cloth, four good cows, two oxen, three steers and four bushels of grain he sells to buy a steed for his son; but instead of a blessing he gives him a message of woe at his departure." "Take care of your cap with the silken birds, and guard your long locks. I dreamt I saw you groping about on a staff, with your eyes out and with a wooden leg; and again I dreamt I saw you standing on a tree, your feet full a fathom and a half from the grass. A raven and a crow sat on a branch over your head, your curly hair was entangled; on the right hand the raven combed it, and on the left the crow parted it. I repent me that I have reared you."

How well-founded the father's warnings against court life are, is shown by the second series of scenes: the temporary return of Helmbrecht to his

2 Verses 429 ff.; $516 \mathrm{ff}$; $5^{80} \mathrm{ff}$. 
home after the first year of his chivalric adventures. At the first meeting with his family he affects the courtly fop. The sister he greets in Latin, the father in French, the mother in Bohemian; and, only upon the earnest entreaty of the father to speak a word of simple German, he at last condescends to acknowledge himself as his son. But soon he reveals the whole brutality and viciousness of the aristocratic highwaymen into whose company he has been received." "Father, it is now more than a week that I have drank no wine; since then I have taken in my girdle by three holes. I must capture some cattle before my buckle will return to its former place. A rich farmer has done me a great injury. I saw him once riding over the crops of my godfather the knight; he shall pay dear for it. I shall trot off his cattle, sheep, and swine, because he has trampled over the fields of my dear godfather. I know another rich farmer who has also grievously injured me; he ate bread with his pastry; by my life, I will revenge that. There is yet another simple fool who was unseemly enough to blow the froth of his beer into a goblet. If I do not revenge that, I will never gird sword to my side, nor be worthy of courting a lady." The father asks who the noble companions

1 Verses III 5 ff. 
are who have taught him to rob a farmer of his all if he eats pastry and bread together; and the son names them: Sir Lambgobbler, Sir Ramswallower, Sir Hellsack, Sir Shakepress, Sir Gobletjerker, Sir Wolf's Jaw, Sir Wolf's Gut and so on. Of himself he says:" "I am called Sir Countrygobbler. I am not the delight of the peasants. What the peasants have is mine. I gouge the eyes of one, I hack the back of another, I tie this one down on an ant-hill, and another I hang by his legs to a willow." Now at last the father's righteous indignation breaks forth: ${ }^{2}$ "Son, however noble those may be whom you have named and extolled, yet I hope, if there is a just God, the day will come when the hangman may seize them, and throw them off from his ladder."

While the clear eye of the father thus sees through the whole nefariousness of this aristocratic gang of robbers, Gotelind, the foolish sister, is blinded by the false splendor of Helmbrecht's adventures. Her vanity is flattered when one of his companions, the wild Sir Lambgobbler, wooes for her hand. Secretly she leaves father and mother, and elopes with her paramour. The wedding of the fine pair and the coming on of the long delayed punishment, closely connected with it, form the third stage and the climax of the whole story.

1 Verses $1237 \mathrm{ff}$.

2 Verses I257 ff. 
"Many widows and orphans" - so runs the account ${ }^{1}$ - "were robbed of their property when Sir Lambgobbler and his bride Gotelind sat at their wedding table. From far away there were brought in wagons and on horses stolen food and drink to the feast. The wedding of King Arthur and Ginevra was nothing compared with the revelling at Sir Lambgobbler's castle. It was wonderful how the food disappeared before the revellers, as if a wind blew it from the table; they ate incessantly of everything that was brought from the kitchen by the servants, and there remained nothing but bare bones for the dogs. Then came true what a wise man has said: 'When anyone eats with excessive greed, it is a sign that his end is near.' Yes, it was the last time that they feasted together. Gotelind began to shudder and exclaimed: 'Woe to us! Some misfortune approaches; my heart is so heavy! Woe is me that I have abandoned my father and mother; whoever desires too much, will gain little; greediness leads to the abyss of hell.' " - Hardly is the banquet ended when the judge and the executioners appear. The knights are overpowered. Nine of them are hanged. Helmbrecht has his eyes put out and one hand and one foot cut off. Thus, as a miserable cripple, he takes

${ }_{1}^{1}$ Verses I464 ff.; I 557 ff. 
leave from his sister as she lies, benumbed with fright, by the roadside.

Finally, the last two gruesome scenes: the rejection of Helmbrecht from his father's house and his ignominious death.

"When ${ }^{1}$ the blind Helmbrecht, limping on a staff and led by a servant, came to his father's house, hear how his father greeted him: 'Dieu salue, monsieur Blindman, go from hence, monsieur Blindman; if you delay, I will have you driven away by my servant; away with you from the door!' 'Sir, I am your child.' ' Is the boy become blind who called himself Sir Countrygobbler? Hey, how cocky you were when you rode off on the steed for which I gave my cattle. Begone, and never return again!' Again the blind man spoke: 'If you will not recognize me as your child, at least allow a miserable man to crawl into your house and lie under the staircase, as you allow the poor sick to do. The country people hate me; I cannot save myself from them.' The heart of the old man was shaken, for the blind man who stood before him was his own flesh and blood - his son; yet he exclaimed with a scornful laugh: 'You went out daringly into the world; you have caused many a heart to sigh, and robbed many a peasant

1 Verses $1707 \mathrm{ff}$. 
of his possessions. Think of my dream. Servant, close the door and draw the bolt; I will have my night's rest.' So the blind man went away, and the peasants hooted and scoffed at him."

"Early ${ }^{1}$ one morning when he was going through a forest, some peasants who were gathering wood saw him, and one of them, from whom he had taken a cow, called to the others for help. All of them had been injured by him. One of them cried: 'I'll tear him into pieces as small as the motes in the sunbeams; he stripped my wife and myself naked.' Another said: 'He broke into my cellar and plundered it.' The fourth, trembling like a reed with passion, shouted: ' I will wring his neck; he thrust my sleeping child into a sack, and when it awoke and cried, he tossed it out into the snow, so that it died.' The fifth roared: 'He has ravished my daughter. If he were thrice as blind as he is, I would hang him all the same.' Thus they all turned against Helmbrecht. 'Now take care of your silken cap!' The embroidery which had been left untouched before was now torn, and scattered on the road with his hair. They allowed the miserable wretch to make his confession, and one of them broke a piece of dirt from the ground and gave it to he worthless man as gate money for hell fire. Then

1 Verses $1823 \mathrm{ff}$. 
they hanged him to a tree. And the father's dream had been fulfilled."

Let us return to our fundamental theme, the evolution of personality in German literature at the end of the Middle Ages. Can there be any doubt that both folksong and popular satire of the thirteenth, fourteenth, and fifteenth centuries present a particularly striking phase of this evolution of personality? Both folksong and popular satire of those centuries foreshadow in a particularly striking manner the great social upheaval which was to come in the sixteenth century; more clearly than any other form of literature do they reflect the democratization of feeling, the rising tide of citizen independence, the imbuing of the masses with the instinct for self-assertion which made Luther's work possible. When Luther appeared, the state of the popular mind had come to be a surging mass of conflicting emotions - of class hatred and party passion, of vulgar cynicism and frivolous skepticism, of bold enjoyment of the flesh and blind groping for the spirit, of sturdy trust in human rights and fanatic craving for the destruction of order. It was Luther's mission to give to this mass of conflicting popular emotions a common moral aim: the striving for individual salvation. 


\section{CHAPTER IV}

THE RELIGIOUS DRAMA OF THE FIFTEENTH CENTURY AND DURER'S BIBLICAL

\section{ILLUSTRATIONS}

T German mysticism, in German folksong, and 1 in German popular satire of the end of the Middle Ages, we observed a constantly increasing democratization of feeling, a constant deepening and heightening of personality, a constantly growing detachment of the individual from the tradition of society. A similar development may be traced in the medieval German drama, more specifically in the process of a constantly growing secularization which led the religious drama from the austere liturgical compositions of the tenth century to the motley popular shows of the fifteenth.

In the Latin Easter Plays from the tenth to the thirteenth century, only slight beginnings of dramatic action and mimic art can be seen. These plays are no plays; they are musical compositions, which at first formed a part of the early Mass of Easter Sunday. In the manner of the oratorio, with a slender admixture of suggested rather than performed action, in antiphonal chants between 
two choruses, later also between choruses and solo voices, they gave to the congregation assembled in church on Easter morning an emotional picture of the events at the grave, the scene between the three Marys and the angel, and the spreading of the news of the resurrection among the disciples. They usually ended with a Te Deum sung by the choir, to which occasionally there was added a hymn of praise sung by the whole congregation. Solemn and liturgical as this whole performance was, it cannot be denied that it contained possibilities of dramatic development and that it step by step widened its circle of action. The display before the disciples of Christ's sudary and shroud, the meeting between Mary Magdalen and the risen Christ, the hastening of Peter and John to the grave, the appearance, at the end, of the transfigured Christ with the banner of the Cross, as victor over death and hell - these were scenes which hardly fitted within the narrow frame of an interlude of the Mass. And to such scenes as these there were added in course of time others which went still further beyond the liturgic origins of these plays: the scene of the three Marys buying ointment or the scene where Pilate despatches his soldiers to watch the grave. We are safe in assuming that not later than the thirteenth century, this 
whole development had led in Germany to that stage in the growth of the religious drama which for France is vouched for by the Mystery Play of Tours as early as the twelfth century: the detachment of the Latin Easter Play from the regular church service.

A similar course of development is seen in the Latin Christmas Plays. To what a variety and vividness of action the Christmas Play of the twelfth century had progressed from its original liturgic limitations, is strikingly shown in the Benediktbeuren Christmas Play. The fact that the text of this play is contained in a manuscript which also contains the largest collection of twelfth century Latin lyrics, the poetry of wine, women and song by the very unclerical order of the clerici vagantes, vagrant theological students who were the despair of the university authorities of that day, is an additional proof for the assumption supported by other reasons also, that these vagrant clerks exercised an important influence upon the secularization and popularization of the religious drama. The stage directions of this Benediktbeuren Christmas Play expressly state that it is to be performed not inside, but in front of a church; ${ }^{1}$ and although the play itself is from beginning to

1 Froning, Das Drama des Mittelalters, iii, 877. 
end in Latin, it often enough appeals to the predilection for strong effects and telling actuality which distinguishes the poetry of the vagrant clerks. In the disputation between the prophets and the leader of the synagogue, with which the play begins, there is no lack of realistic traits. The Sibyl, according to the stage directions, is to pronounce her prophecy of the coming of Christ "cum gestu mobili," " with vivid gestures; and the leader of the Synagogue is to betray great excitement and violent indignation at these and similar prophecies. He is to punch his fellows with his elbow, he is to toss his head and his whole body to and fro, stamp on the ground and wield his stick altogether in the manner of a Jew. ${ }^{2}$ The striving for grotesque imitation of reality which marks this introductory scene appears again and again throughout the play proper, the action of which leads from the Annunciation and the Nativity to the Slaughter of the Innocents and the Death of Herod. Most strikingly perhaps is this the case in the scene of the Shepherds in the Field ${ }^{3}$ who are accosted on the one hand by an angel announcing the birth of the Saviour, on the other by the devil denouncing the angelic message as a preposterous

1 Loc. cit., 878 .

${ }^{3}$ Loc. cit., 892 ff.

2 Loc. cit., 88 o. 
invention. Three times the shepherds set out to perform their worship before the Child in the manger, three times they are sent back by the devil. Finally they are entirely non-plussed by the discrepancy of the arguments hurled at them from either side; they put their heads together and confess to each other that they don't know where to turn. Then, fortunately, there appears a multitude of the heavenly host singing the "Gloria in excelsis deo et in terra pax hominibus bonae voluntatis." This, of course, convinces the shepherds; they cast their doubts to the wind; they proceed to the manger, and now there follows the Adoration scene in strict accordance with the biblical narrative.

These few observations may suffice to remind us of the fact that the ecclesiastical development within itself had led in the twelfth and thirteenth centuries to a religious drama which, although, in the main, confined to the Latin language and to a spirit of austere churchliness, at the same time contained numerous germs of a freer, more secular and more individual conception of life. But only from the fourteenth century on, together with the powerful growth of the great German city republics, and clearly influenced by the spirit of civic independence emanating from them, there develops a German vernacular drama which offers 
room for a broad representation of reality and for a large variety of personal types.

It must frankly be admitted that just as the folksong and the popular satire of the end of the Middle Ages as compared with the courtly lyrics and epics of the twelfth and thirteenth centuries frequently betray a coarsening of motives, so the popular drama of the fourteenth and fifteenth centuries, also, is decidedly less refined than the older prevailingly liturgic drama. Indeed, many of these plays are overcrowded with trivial vulgarity. Especially where, as in the Shrovetide Plays, the ecclesiastical element is either totally absent or present only as an object of ridicule, there is often a display of ordinariness, uncouthness, nay filthiness which deprives this farcical tavern drama of any association with poetry and makes it worthy of notice only as a vulgar by-product of the teeming vitality of an epoch inclined to go to extremes both in spiritual aspirations and in the things of the flesh.

This also must be admitted that the influx of secular matter into the religious drama has not led to the creation of an artistic form in which the spiritual and the material appear reconciled. Only in a few plays belonging to the outer periphery of the ecclesiastical legend, such as the Low German 
"Theophilus" (fourteenth century) or the play of "Frau Jutta" (I480), are we confronted with a consistent central action which upon the background of churchly life presents human passions and conflicts. And just in these plays there is too great a lack of wide perspective for them to arouse deepest human interest. Both the fate of Frau Jutta whose vain enterprise, after having lifted her to the throne of St. Peter, plunges her into sudden downfall, and the career of the priest Theophilus whom ecclesiastical ambition seduces into a compact with the devil, after all serve only to glorify the intercession of the Virgin Mary for the repentant sinner. Both plays lack the compelling force of soul experience. The great mass, however, of the religious plays, especially those which have for their subject the kernel of the Christian legend the birth, the earthly career, the passion, and resurrection of the Saviour - consist of an almost endless agglomeration of glaring contrasts between the church and the world, between the serious and the burlesque, between deepest feelings of the innermost heart and commonplace externalities; all this at the expense of artistic unity and a closely knit composition.

Some of these contrasts, however, are indeed presented in such a manner that we are made to 
feel thereby the tragic complexity of existence, the inevitable interweaving of the high and the low, of blessing and curse, which makes the web of human life. Truly impressive is the contrast in the "Play of the Wise and Foolish Virgins" between the tender, merciful feelings of the Virgin Mary and the austere inaccessibility of the divine Judge himself. His mother pleads for the Foolish Virgins on her knees; ${ }^{1}$ she reminds him of all the toil which for more than three and thirty years she has undergone for him, of all the suffering which his death has brought her; and as a reward for all this she demands from him the pardoning of the repentant sinners. But Christ remains unmoved; with a commanding gesture he imposes silence upon his mother; his only answer to her ever repeated entreaties is a solemn: "Too late, too late"; and with majestic loftiness he commits the poor wretches to eternal damnation. No wonder that when in 1322 this play was produced at Eisenach, one of the spectators, the Landgrave of Thuringia, was affected so deeply that he is said to have collapsed with the words: "What is our Christian faith then for, if God is not willing to be merciful, even at the intercession of his own Mother?"

1 Das Spiel von den zehn Jungfrauen, ed. Otto Beckers, verses $279 \mathrm{ff}$. 
Truly touching is the contrast in the Hessian Christmas Play of the end of the fifteenth century between the glory of the inner life and the outward wretchedness of a proletarian existence. ${ }^{1}$ Mary and Joseph are homeless. They wander from town to town to find a shelter for the approaching confinement of the Mother of God. At every house where they stop they are turned away from the door with harsh words; and even in the vagrants' home where they at last are taken in, old Joseph must submit to the most humiliating insults heaped upon him by two servant girls. When the child is born, the most necessary provisions are lacking. No food, no bedding for the mother, not even swaddling clothes for the infant. But Mary comforts herself: naked are we born, naked are we to go hence. And good Joseph makes a most devoted father. He succeeds in hunting up a cradle for the baby, he gets a pair of old trousers which will do very well for swaddling clothes; and then, how happy he settles down at the cradle, rocking the little one and singing it to sleep with a German lullaby.

And even the Merchant scene of the Easter Plays, although it often goes to the very limit of the endurable in coarseness and triviality, at times

1 Froning, iii, 902 ff. 
gives us a sense of the fundamental paradox of life which so frequently makes moments of supreme solemnity and portentousness clash with incidents of utter clownishness and frivolity. In the Vienna Play, ${ }^{1}$ the scene begins like a country fair scene by Teniers or some other Dutch genre painter. The merchant, a quack and mountebank of the first order, professes just to have come from Paris and to have bought there a great supply of salves, tonics, and domestic wares, the usefulness of which he is not slow to impress upon the crowd gathered about his booth. In the crowd he notices a fellow whose face appeals to him as betokening a kindred soul: Rubin, the Jew, pickpocket, gambler, and counterfeiter. Everywhere this Rubin has managed to defy or escape the courts; only in Bavaria they once caught him and branded his cheeks. Rubin is engaged by the merchant as a fellow salesman, and the two together proceed to harangue the multitude. Suddenly there arises from the midst of the concourse, like a voice from another world, a wailing song - the lamentation of the three Marys over the death of Jesus, followed by their mutual exhortation to go to his grave and to anoint his body with ointment. The quack sees his chance for a good bargain; he sends Rubin to

1 Hoffmann, Fundgruben, ii, $313 \mathrm{ff}$. 
coax the women to his booth. The three Marys apparently do not know the value of money; they offer to pay all they have, three gold florins; and the merchant is so overcome by this unexpected readiness of his customers that he in turn gives them better stuff than he is accustomed to give. But here his wife, who, it seems, has a better business head, intervenes. She has made the ointment herself, she says; she ought to know better how much it is worth; she bids the women not to touch it. And when her husband insists on keeping his agreement, she abuses him as a drunkard and spendthrift - an attack which he answers by beating and kicking her. In short, the vulgarity and ugliness of everyday reality smother the finer feelings of the heart which the lamentation of the three Marys had kindled. But these feelings are rekindled by the following scene at the grave, the joyful message by the angel of Christ's resurrection and the expression by the three Marys of hope and trust in the living Saviour:

Jesu, du bist der milde trost,

Der uns von sunden hat erlost,

Von sunden und von sorgen,

Den abent und den morgen.

Er hat den teufel angesiget,

Der noch vil feste gebunden liget.

Er hat vil manche sele erlost:

O Jesu, du bist der werlde trost. 
If scenes of contrast, like those mentioned, serve to give to the religious plays of the fifteenth century a remarkable variety and lifelikeness, the absence of unity in them, of which I spoke before, is not always equally pronounced. Indeed, overcrowded as many of these plays are with multifarious matter, awkward as is their language, dragging as is their action, lacking as they are in artistic unity, they are not without spiritual unity. The best of these plays give us perhaps the most comprehensive picture of a time in which the sacred legend had passed over into the life of the whole people and had become the personal property of every individual. They make us realize the state of mind of a multitude for whom the passion and the resurrection of the Saviour was an ever recurrent and ever present fact, closely allied with their own local surroundings and local happenings; a multitude, who in the stations of Christ's passion carved in stone and bordering the road between the city wall and some churchyard, had constantly before their eyes the road to Golgotha; a multitude to whom it would not have seemed incredible, if the baptismal font in the minster during divine service suddenly were to change into the Jordan and receive the sacred forms of John the Baptist and the Saviour bowing down before him, while from above 
there would be heard the word: "This is my beloved son, in whom I am well pleased." The spectators themselves gave unity to these plays, through their personally re-experiencing an action with every detail of which they were thoroughly familiar and every part of which was to their mind intimately connected with the whole.

Two of these plays - an Easter Play written in I 464 by a priest at Redentin near the Hanse town of Wismar on the Baltic Sea, and a Passion Play performed in 1501 in the Hessian town of Alsfeld, not far from Frankfurt - it may be worth while to sketch at least in outline.

Hardly anywhere has the localizing and modernizing of sacred history been carried to such an extreme and has there at the same time been maintained such a high level of artistic form as in the Redentin Easter Play. The play begins with the resurrection of Christ, but the resurrection takes place, not in Jerusalem, but in the good old town of Wismar itself. Pilate, who appears as the type of a stately, somewhat phlegmatic burgomaster, hears a rumor that Christ's followers intend to steal his body; and he therefore details four knights to watch the grave, one to the north, one to the south, one to the east, and one to the west. The knights behave in a very martial manner, and their whole 
conduct is clearly a caricature of the depraved robber barons and predatory mercenaries who in those times of club law were an object of both terror and ridicule to the peaceful citizen. They brag about their prowess, clatter with their swords, threaten to smash any one who shall dare to come near them; and then go quietly to sleep, having first made an arrangement with the city night watchman, who is stationed on the steeple of the cathedral, to keep on the lookout in their place. The watchman sees a vessel approaching on the Baltic Sea. He tries to wake the knights, but in vain. He hears the dogs barking, and again vainly tries to arouse the sleepers. He calls out the midnight hour. And now a chorus of angels is heard on high, the earth is shaken, Jesus rises from the grave and proclaims the redemption of mankind:

Nu synt alle dynk vullenbracht,

De da vor in de ewicheit weren bedacht,

Dat ik des bitteren dodes scholde sterven

Unde dene mynschen gnade wedder vorwerven. ${ }^{1}$

From these scenes, in which the burlesque and the serious are so quaintly mingled, we now pass on to events of truly sublime simplicity and serene grandeur. Jesus descends into hell, to rescue the souls of the forefathers. His approach is fore-

1 Froning, i, 133 . 


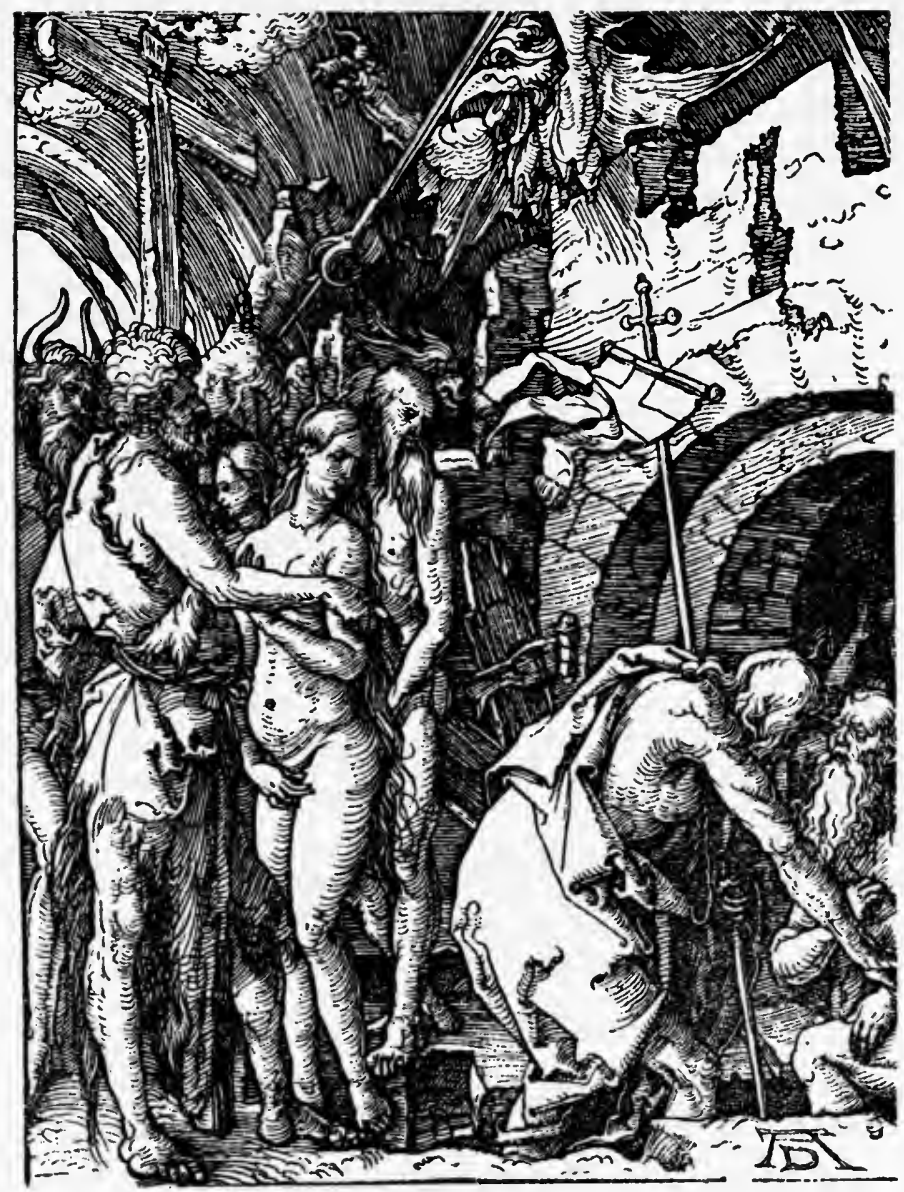

THE HARROWING OF HELL

From Dürer's Little Passion 

shadowed in the joyous expectancy of the waiting souls. They see a wondrous light spreading overhead. Abel is the first to interpret this as a sign that the time of their redemption is nigh; but the others at once join with him. Adam rejoices in the hope of regaining paradise. Isaiah is sure that this is the light of God; for is it not an evident fulfilment of what is written in his own book of prophecy (he quotes himself in Latin): "The people that walked in darkness have seen a great light "? And Seth recalls the twig which five thousand and six hundred years ago he planted at God's behest that it might grow into the tree of salvation, the cross. Now, John the Baptist appears as forerunner of the Saviour, and announces his coming. In vain do Lucifer and Satan summon their hosts, in vain do they lock the gates of hell. Surrounded by the archangels, Christ advances. With a few majestic words he silences Satan, the " accursed serpent "; with a mere sign of his hand he bursts the gates; Lucifer he commands to be bound until the day of Judgment. And now the souls stream forward, exulting, jubilating, stammering with joy and gratitude; and Christ takes them by the hand and greets them, and then commits them to the care of Michael, the archangel, that he may lead them upward into paradise. 
At the end of the play we return once more to the sphere of the burlesque, to a satire upon social conditions of the fifteenth century. Through the rescue of the souls of the Fathers, hell has become desolate; Lucifer therefore, chained as he is, sends his servants out to catch new souls. But the devils return empty-handed and discouraged: through Christ's death and resurrection, they say, the world has become so good that very little chance is left for hell. Lucifer, however, is not discouraged. He has heard that a great plague is raging just now in the city of Lübeck, the rival town of Wismar, and he sends his messengers out for a second time, to try their fortunes in the Hanse town. And this time they come back laden with souls of sinners, sinners of every kind and description. There is the baker, who deceived his customers by using too much yeast in his bread and too little flour. There is the shoemaker, who sold sheepskin for Cordovan leather. There is the tailor, who stole half of his customers' cloth. There is the inn-keeper, who adulterated his beer and served it with too much foam in the pot. There is the grocer, who used false measure and weight. There is even the priest, who so often overslept the mass and so often celebrated the vesper service in the tavern. In short, - this is the moral with which the play at the end 
returns to the Easter theme-Lucifer is right: the power of evil has not yet been broken; $\sin$ is still mighty in the land; only by cleaving to God and his word can we be saved. Only then can we truly sing with the angels: "Christ is risen."

In unity and perspicuity of composition the Alsfeld Passion Play, extending as it does over three play days and containing as it does more than eight thousand lines, cannot be compared with this truly classic Redentin Easter Play. The Alsfeld play often drags and is often full of platitudes and of insufferable loquacity. But the cardinal motive of the whole, the conflict between the powers of darkness and light, is well conceived and shines forth from the unending succession of events again and again with genuine power.

The distribution of the unwieldly material of the Alsfeld play upon the three days of the performance is not without dramatic skill. The first day begins effectively with a council of devils, in which Lucifer and his prime minister Satan introduce their plan of bringing about the death of Christ apparently without realizing that through the execution of this plan they are bound, against their will, to further the cause of salvation. As a prelude to Christ's passion and death, there follows the John the Baptist episode: his incarceration, the 
feast of Herod, the dance of Herodias' daughter, the death of John, the punishment of Herodias and her daughter. The rest, that is the larger half, of the first day is devoted to Christ's public career, from the calling of the disciples to the Last Supper, with the emphasis laid upon the miracles performed by Christ, among which the raising of Lazarus and the transformation of Mary Magdalen from a vain daughter of the world into a pious penitent stand out with particular vividness. The second day brings the preparatory events of the Passion. It commences with the Last Supper and reaches its climax in the trial of Christ before Pilate, in which God the Father, surrounded by the archangels and the heavenly host, appears as a witness to the glory of his son, humbled and degraded into a poor sinner. A disputation between the allegorical figures of Ecclesia and Synagoga, the representatives of the two contending principles of good and evil which direct the action of the whole play, brings the second day to a logically, if not artistically, satisfactory conclusion. The third day, finally, rises to the greatest events of the sacred legend. The bearing of the Cross, the lamentation of Mary, the crucifixion, the resurrection, the harrowing of hell, the scene at the grave, the ascension, the descent of the Holy Ghost - all 
this is passed in review before us, with hardy realism, with strong accents and with broad effusion of feeling; so that the last scene, the parting of the Apostles as they set out to wander through the world and to convey the glad tidings of salvation to all mankind, indeed dismisses us with the impression of a great personal experience.

Only one of the many and variegated episodes which make the whole of this motley Alsfeld play I should like to analyze a little more fully, in order to bring out once more the truthful directness and simplicity in the representation of personal character in which the principal merit of all these plays is to be found: I mean the John the Baptist episode of the first day of the performance. ${ }^{1}$

By his bold stand against the vicious Herodias and by his preaching of penitence to the people, John has alarmed hell. Lucifer is afraid of him; he fears he might win the world over to God; he therefore decides upon his death and he despatches Satan to execute it. Satan assumes the disguise of an old woman and enters the palace of Herodias. In the manner of a witch, he accosts her with insinuating flattery and inquires why her eyes are so red with tears. Herodias blurts out at once: "That has been done to me by the evil John. He

1 Froning, ii, 584-606. 
has spoken so ill of me that I can have no joy unless I have revenge on him." Satan answers:

Folget mir, frau! ich will euch lehren;

Ihr sollt euch machen an euren herren;

Den könig Herodes sollet ihr bitten

Mit schreienden augen nach weibes sitten

Und sollet ihm öffnen euer leid!

So weisz ich wohl, er wird bereit,

Dasz er tut all euren willen.

Eure schreienden augen wird er stillen;

Und was ihr dann von ihm begehrt,

Des seid ihr dann von ihm gewährt.

Er lässet euch in keinen nöten,

Und sollte er den bösen mann lassen töten,

Der euch so leide hat getan.

Damit will ich von hinnen gan.

Gebet mir urlaub, fraue zart!

Ich will mich machen auf mein' fahrt! ${ }^{1}$

In reality, however, he does not leave, but only steps aside; and in all the following scenes he remains as an unobserved observer in the background.

Herodias acts upon Satan's counsel. She declares to the king, she would never be happy and he would never have a dutiful wife in her, unless he were willing to put to death the "rudely mannered man " who had scolded her so fiercely. The king is only too willing to enter upon this; he embraces his wife, draws her close to him on his

1 Verses 7 2 ff: 
chair, calls her his dear darling whose fair body was dearer to him than all the treasures of the world, and bids her to be of good cheer; for her wish would be fulfilled. John is arrested, dragged hither and thither by the brutal soldiers, and finally thrust into a dungeon; all this, without his uttering a single word of protest or complaint. His disciples, from whose midst he has been snatched, follow him to the prison gate, and stand about frightened and disconsolate, longing for their lost master. The king, however, happily rid of the irksome preacher of penitence, wants to celebrate his birthday in merry good fashion: the table is to be crowded with game and fish, with pastry and wine; his whole retinue is to feast and carouse; and Herodias and her daughter are to sit next to him and forget all sorrow and care.

Now there follows the dance of Herodias' daughter. The king attaches to his request for a dance the well known promise to fulfill any wish which the daughter might ask. After she has danced, he insists upon her naming her wish. The girl cannot make up her mind; she must ask her mother's advice about it. And now, while mother and daughter consult with each other, Satan, still in his disguise of an old hag, comes forward from the background and whispers into their ears, "Ask for 
John's head; for as long as he lives, you won't be rulers of the land." Eagerly the passionate Herodias seizes this suggestion; and willingly her daughter, the heartless and vain society girl, enters upon it. With a dutiful curtsy she accosts the king and names her wish. The king, after a brief struggle with himself, grants it.

This leads to the climax of the action. The beheading of John is carried out by the king's brutal satellites storming into the dungeon and dragging him out with insults and contumelies. Herodias' daughter receives the bleeding head without any sign of horror and with a conventional smile. Holding it before her on the platter and striking up a song of rejoicing, she dances about. But in the very moment when she passes John's head over to her mother, Satan suddenly reveals his true self, he throws off the disguise of mantle and veil, and standing erect and threatening in all his diabolical grimness, he shouts:

Hoiho! Hoiho! ich hab gesehen,

Dasz all mein wille ist geschehen!

Der mann in unschuld ist ermort!

Drum will ich eilig laufen dort

$\mathrm{Zu}$ meinem herren Luzifer,

Und will ihm bringen gute mär.

Ich weisz, er wird mich wohl empfahn,

$\mathrm{Da}$ ich solch liebe ihm getan. ${ }^{1}$

1 Verses ro40 ff: 
Hell rejoices at the welcome news. The devils storm upon earth, enter the palace, seize Herodias and her daughter, and drag them, regardless of their cries for help and their woeful lamentations, down to eternal perdition.

We may say that all this is good, healthy, homemade food. Nothing of the brilliant complexity of Heine's Herodias. ${ }^{1}$ Nothing of the theatrical cleverness of Sudermann's Johannes. Nothing of the perverse sensual passion of Oscar Wilde's Salome. The characters of this Alsfeld Play are direct, transparent, naïve; they offer us no riddles to solve; they do not shock our nerves. But how vividly and clearly do these figures stand before us: John, the fiery preacher of penitence, and at the same time the humble man of non-resistance; Herod, the bragging tyrant and the henpecked husband; the impassioned, ambitious Herodias; her daughter, the pretty and soulless society doll; and above all Satan with his craftiness and versatility, with his grim maliciousness and his blind rage for destruction. In characters and scenes like these, the Christian legend, we feel, has come to be entirely acclimatized to German city life of the fifteenth century; it has come to be a perfect expression of the personal experience of the average citizen of those days.

1 Atta Troll, c. 19; Werke ed. Karpeles, ii, 152 ff. 
I have tried to reproduce something of the wealth of personal feeling and personal character contained in the religious drama of the fifteenth century. It seems proper to conclude with a few remarks upon a man who, although in a different field of art, has given to this tendency toward imbuing sacred legend with the fullness of personal experience its consummate artistic form, Albrecht Dürer. The parallelism that exists between the German religious drama and German religious painting of the fifteenth century could not be better illustrated.

While Holbein was a man of a distinctly secular frame of mind and therefore pursued his path either away from medieval tradition, or (as in his Dance of Death) in direct opposition to it, Dürer found the perfection of his artistic personality in the inner assimilation of this tradition. Proof of this is above all the four great series of woodcuts which appeared between $I_{498}$ and I5II, the Apocalypse, the Life of Mary, the Large Passion, and the Little Passion. These woodcuts belong to the formative period of his life; they show him in the midst of his mental conflicts: losing himself in the mysteries of scholastic speculation; refreshing himself in the pure fountain of sacred legend; protesting against the corruption and worldliness of 
the church of his day; in spite of doubt and disappointment clinging to the faith that at last there will come a time when the dream of the ages, the advent of the New Jerusalem, will be realized.

Throughout the fifteenth century the figures of sacred legend had been presented to the popular eye not only upon the stage of the religious drama, but also in countless paintings enshrined in churches and convents. And in painting no less than in the drama, there had been a constant attempt to reconcile deepest soul experience with objective representation of outer reality. In the monumental calm of the Ghent altar, in the emotional intensity of Rogier van der Weyden, in the mild beauty of Memlinc and the serene transparency of Dirk Bouts, in the idyllic charm of the Cologne masters and the naive contemplativeness of Schongauer and Wohlgemut, religious painting of the fifteenth century had achieved wonders of truly popular art. This whole movement reaches its climax in Dürer. In Dürer all that medieval Christianity had gathered in power and delicacy, ecstatic passion and idyllic contemplation, fantastic longing for the infinite and lusty enjoyment of the present, is brought together and united into a compact and mighty artistic personality. 
The fantastic element predominates in the scenes from the Apocalypse. ${ }^{1}$ But all the more remarkable is the sure sense of reality with which Dürer succeeds in giving form to the ecstatic visions of oriental imagination and in adapting them to the feelings of his own people and his own time. Like an event of real life appears the opening of the gates of heaven, the third cut of the series. Dürer transports us here into a romantic landscape showing the characteristic traits of his Franconian homeland: forest, rock, and lake, castles on hilltops, mountains in the distance. Above all this, in the clouds, the scriptural vision, but likewise conceived in the forms of the life which surrounded Dürer himself. The gates of heaven are evidently the portals of some medieval cathedral; the throne of God stands in the choir of this cathedral; the seven lamps of fire above the throne have the shape of medieval church vessels; and at the right and the left there sit in richly carved choirstalls the twenty-four Elders, like canons of a cathedral chapter. The Elder furthest in the foreground at the left turns with a friendly gesture to the reverently kneeling John the Evangelist. The whole composition calls up the feelings 1896.

1 Edited, in phototypic reproduction, by J. N. Sepp; München, 


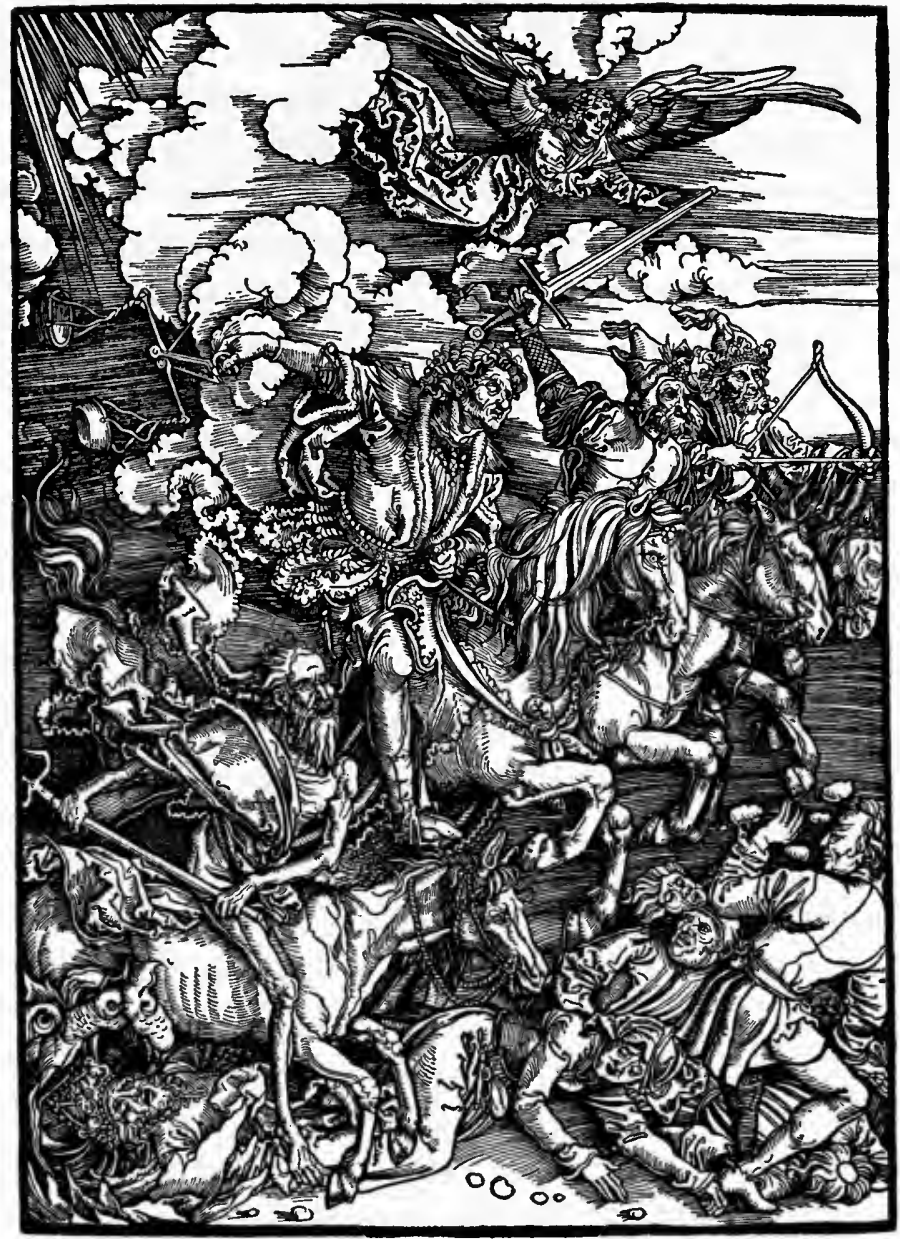

THE APOCALYPTIC RIDERS

From Dürer's Apocalypse 

which we experience in entering a venerable church; and only the clouds on which the heavenly apparition rests, and the rays of light which break forth from the opened gates, transport us into the world of visions.

Of grandiose dramatic effect are the plates which have for their subject the executors of divine Judgment, above all the angels of wrath and the four apocalyptic riders. In representing the apocalyptic riders Dürer omits the landscape entirely, in order to concentrate the attention upon the four gruesome riders, galloping away over unhappy mankind: Pestilence shooting its arrow, War brandishing its sword, Famine swinging a pair of empty scales, Death jogging along on a jaded nag and flourishing the infernal trident. We entirely forget the allegorical character of these figures. We only feel their irresistible storming onward, all the more forcibly, since we do not see whence or whither they storm. They break forth, as it were, from the dark; and we are immediately in front of the hoofs of their horses, as they trample down whatever is in their way. Of similar dramatic intensity is the picture of the work of destruction wrought by the angels of wrath. Dürer represents them as tall, gaunt, bony men with vultures' wings, filled, one might say, with apathetic grim- 
ness and cold revenge. Swinging their swords, they are wading through a surging mass of human bodies, from which there emerge in wild confusion figures of despair, of impotent struggling, of the dying and the dead. One of the angels seizes a woman by her hair; another strikes down horse and rider; a third brandishes his sword over an old man who in vain appeals to his mercy; a fourth has seized the pope by the shoulder, as he lies on the ground; while the emperor, likewise on the ground, tries to protect his tottering crown. One feels the approaching breakdown of medieval society in this fierce, passionate conception.

What a contrast between the solemn grandeur of these Apocalyptic visions and the idyllic charm of Dürer's Life of Mary. ${ }^{1}$ Many as are the medieval poets and painters who have vied with each other in glorifying the Virgin, none of them have treated her legend in as truly popular a manner as Dürer. None of them have made the Queen of Heaven so human, so bourgeois, so German.

Abounding in variety of characters are the introductory scenes from the legend of Joachim and Anna. In the Refusal of their Offerings by the High Priest, on account of the childlessness of their

1 Edited, in phototypic reproduction, by Bruno Meyer; Leipzig, 1887. 
marriage, the contrition of Joachim, the mute despair of Anna effectively contrast with the sympathy, the indifference, the contempt of the crowd of bystanders. The appearance of the angel before Joachim in the wilderness, with the glad tidings that God has heard his prayer for a child even in his old age, is represented with telling naivveté. The scenery is a forest by the sea; sheep are grazing on a pasture; the shepherds seeing the vision from on high, raise their heads and spread their arms in utter amazement. The angel brings the divine message in the form of an official parchment, on which not even the seal is lacking. Old Joachim in the foreground bends his knees, overcome with emotion.

Touching is the meeting of Joachim and Anna, at the golden Gate of Jerusalem, after his return from the wilderness. He has just imparted to his wife the angelic message. In speechless happiness she leans on her husband's breast, received by him with loving tenderness. A number of bystanders seem to engage in gossipy conversation about them. A vivid picture of German burgher life is presented in the Birth of the Virgin. In the background lies Anna in bed, weak and exhausted, tended by two women friends, while a third is sitting by the bed, apparently resting from the exer- 
tions of a sleepless night. The foreground is filled with a whole crowd of gossips and neighbors, being in various stages of excitement over the advent of a little daughter in the house. One of the women is giving the new born baby a bath, others are busy with the swaddling clothes, still others are eagerly discussing the great event, while a mighty beer-jug goes the round among them. Only the angel hovering over this scene, swinging a censer, reminds us that it is not an every day incident from Dürer's own time and surroundings.

And now there follows the life of Mary herself, and the childhood and early manhood of her son, told with the same naïve assimilation of the sacred legend to the sphere of German burgherdom and with the same power of individual characterization. Five of these scenes may serve to illustrate Dürer's wealth of motives and the popular truthfulness of his manner: the Visitation, the Presentation in the Temple, the Flight into Egypt, the Sojourn in Egypt, and the Leave-taking of Jesus from his Mother.

Something like foreboding expectancy surrounds the Visitation. It takes place in a gorgeous landscape, fantastic rocks and mountain tops looming up over wide stretches of woodland. While the women embrace each other, Zacharias appears at 


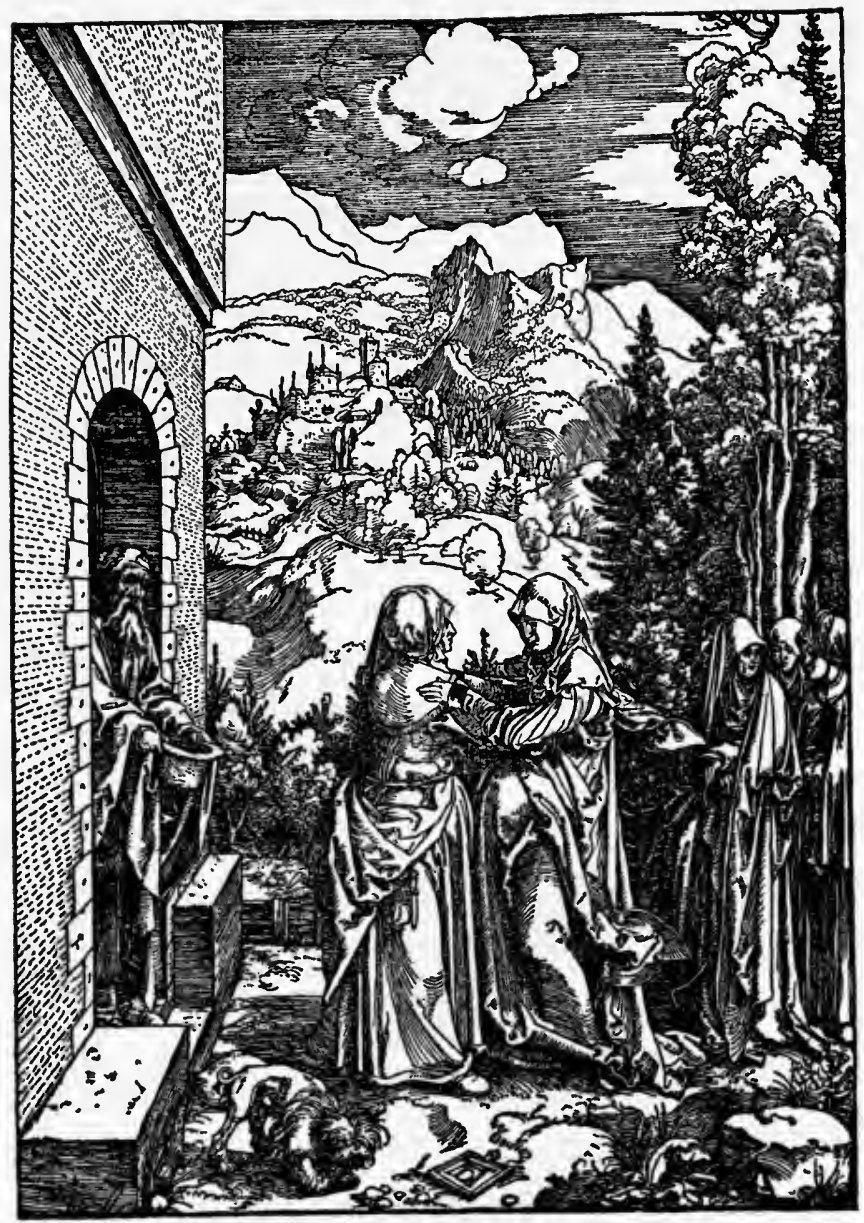

THE VISITATION

From Dürer's Life of Mary 

the door, his felt hat in his hand, looking at them with a somewhat troubled expression. Full of solemn calmness, on the other hand, is the Presentation in the Temple. Most impressive is the noble Renaissance entablature supported by massive columns under which the sacred ceremony is being performed; through the columns one sees into the mysterious darkness of the temple. With patriarchal benignity old Simeon bends over the little child; reverently and demurely Joseph and Mary look on; an air of calm edification lies over the crowd of friends and relatives silently standing by.

The Flight into Egypt, conceived after a print of Schongauer's, shows the holy family on their pilgrimage, journeying very much in the same manner in which German peasants of Dürer's time would journey to a country fair. Good Joseph is trudging along in front, carrying most of the baggage on his back, leading the ass on which the mother sits, the baby on her lap, her big traveling hat hanging over her shoulders. Even the cow the thrifty people have taken along, so that they will not suffer want in foreign lands. The Sojourn in Egypt also takes us to the Germany of the fifteenth century. Joseph has established his carpenter shop in the courtyard of a rambling, half tumbled 
down building, such as Nürnberg in Dürer's time must have had many. He is just pausing from his work, and gazing thoughtfully at the group next to him: the young mother sitting at the distaff and at the same time rocking the baby in the cradle, while adoring angels, like good fairies, bend over the child to bless it. Little winged genii are playing around Joseph, collecting chips of wood into a basket, running about with toy wind mills, trying to blow on sticks of wood as on trumpets. One of them has even playfully cocked Joseph's hat upon his little head. Above, in the clouds, there appears the figure of God the Father, with patriarchal satisfaction looking down upon this peaceful picture of domestic happiness. In striking contrast with these idyllic scenes, finally, one of the last cuts of the whole series: Christ's leave-taking from his aged mother, before his last journey to Jerusalem. Here everything is grand and pathetic. Christ, a heroic figure, is turning to go. His austere and solemn attitude shows that he is ready to take the cross upon him. For the last time, he blesses his mother who, wringing her hands despairingly, sinks down in anguish. Two women companions beside her; one of them seems to beseech Jesus to have pity on his heart-broken mother; the other one wraps herself in her mantle with an expression 


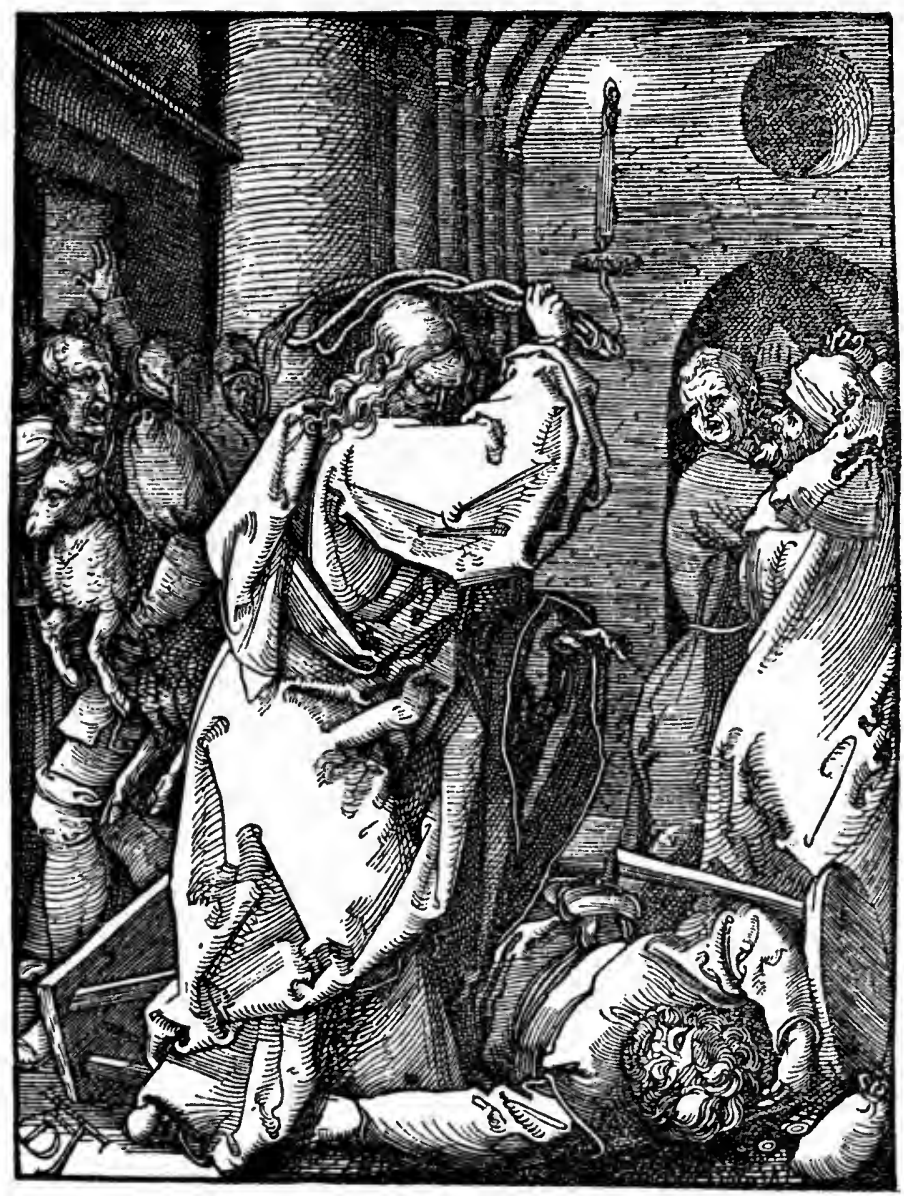

THE CLEANSING OF THE TEMPLE

From Dürer's Little Passion 

of horror. Here we feel that the time of Christ's Passion is approaching.

The Passion of the Lord, Dürer has represented many times, in individual scenes as well as in cycles of scenes; most impressively, however, in the two series of woodcuts called the Large and the Little Passion. The Arrest of Christ and the Bearing of the Cross in the Large Passion, the Man of Sorrows, the Cleansing of the Temple, Gethsemane, Christ before Pilate, the Crown of Thorns, the Harrowing of Hell in the Little Passion ${ }^{1}$ - what a gallery of soul portraits, what monumental art, an art reduced to the essentials, crowding into narrow compass a world of deepest feeling.

In the Man of Sorrows, all the sufferings of Christ have been concentrated into the figure of the lonely sitting man, bent together, wrestling with himself. In the Cleansing of the Temple, Christ's scorn and indignation over the desecration of the sanctuary are brought out not so much by his face - the face is almost concealed from view - as by the irresistible forward movement of his whole body and above all by his heavy, flowing garment which gives to this forward movement weight and momentum. In the Arrest of Christ, it is the

1 Edited, in phototypic reproduction, by Bruno Meyer; Leipzig, 1887 . 
rhythm of contrasting movements which reveals the inner life. Christ is in the midst of a wild popular tumult. The shouting, roaring soldiers are dragging, pulling, pushing Christ along. From the darkness of the background Judas stealthily approaches for the traitorous kiss. While Christ is being swept along in this mad torrent, he seems inwardly raised above it. Only the lower limbs are instinctively yielding to the force that draws him forward. His head is thrown back and seems to see heaven opened. In the Bearing of the Cross, it is above all the eye of Christ which holds us in its spell. Christ has succumbed under the weight of the Cross. He has sunk down upon his knees. With one arm he holds the cross on his shoulder, with the other he supports himself upon the stump of a tree. Thus he looks back with a glance of nameless woe but complete self-renunciation upon his followers, as though he were saying: "It is for you that I grieve, not for myself.'

Thus we might go through this whole series of scenes and everywhere we would be forced to make the same observation. It is the intense individualization, the deep personal experience that gives to Dürer's representations of the Christian legend their compelling power, that makes them universally human documents. The mystics of the 
fourteenth century, as we have seen before, transformed the ecclesiastical doctrine into an inner experience of the individual self. The folksong of the end of the Middle Ages created an image of the outer world from the depth of individual feeling. Satirical narrative measured society by subjective standards. The religious drama clothed the biblical events in the garb of contemporary life. All this re-echoes in Dürer's work and makes him look at the whole mass of medieval tradition, reverently to be sure, but with perfect spiritual freedom.

In his Holy Trinity of $\mathrm{I}^{\mathrm{I}} 3$, this whole medieval world once more comes to view in all its fullness and glory. This painting is indeed a glorification of the all-embracing, universal church, a worthy counterpart and companion of the Ghent altar of the brothers van Eyck. A wonderful unity holds together these countless figures which, high above in the heavenly regions, congregate, in four concentric circles, about the Trinity: winged heads of the Seraphim, angels carrying the insignia of Christ's Passion, the Saints and Martyrs led by the Virgin Mary, the Patriarchs and Prophets of the Old Testament led by John the Baptist, the vast multitude of believers, both clergy and laity. All are imbued with the same feeling of religious rap- 
ture, all are blissful in the sight of the divine. But at the same time, what a variety of types, from pope and emperor down to burgher and peasant! How deeply conceived, how clearly differentiated the faces! What a wealth in personalities! And below this whole heavenly apparition, in a wide lonely landscape, stately and erect, wrapt in his mantle, his masterful and thoughtful eye gazing into the distance, there stands the man from whose innermost self this fullness of visions has sprung; and his feeling of self is expressed in the inscription next to him: Albertus Dürer Noricus faciebat.

This painting is the last great medieval creation of German art. It is a forerunner of an era of universal and free humanity. 


\section{CHAPTER V}

THE HUMANIST ENLIGHTENMENT: ERASMUS

70 appreciate fully what at the beginning of the

1 sixteenth century was at stake for German culture, we must remember that the two preceding centuries had been signalized by a constantly rising tide of individualism. In the ecstatic rapture and the deep inwardness of the mystics of the fourteenth century, in the freedom and directness of folksong, in the grotesque subjectivity of the bourgeois satire, in the secular liveliness of the religious drama, in the intense truthfulness of religious painting, this movement, directed toward a heightening and intensifying of personality, had found its most characteristic expression. Now, at the beginning of the sixteenth century, it seemed as though this movement was about to lead to a classic era of noble humanity, as though Humanism and Reformation, allied in a common struggle for freedom, were to inspire the German people with a new idealism and a new faith.

To be sure, the achievements of German humanism have frequently been overrated, not only by the humanists themselves but also by their modern 
admirers. The great chivalric poets of the twelfth and thirteenth centuries and the great mystics of the fourteenth century had penetrated more deeply into the problems of life, they had recognized more clearly the necessity of self-discipline for the development of true personality than most of the pretentious humanist " poetae" who talk so much about their own precious ego. In vying with their chosen models, the great writers of Greece and Rome, the humanists remained nothing but cold imitators. Their supercilious turning away from the life and the language of their own people brought about that baneful division of the people into so-called educated and so-called uneducated which has given to German culture down to Lessing the prevailing stamp of artificiality and unnaturalness. And personally, the humanists, as a rule, were by no means such pure and undefiled idealists as they themselves took pains to make themselves appear to be. On the contrary, as typical figures of a time out of joint socially and spiritually, the majority of their spokesmen were inclined to all sorts of license and excess and often lacked conspicuously in steadfastness of moral purpose. Nor can the German humanists, in particular, be compared in beauty and grace of utterance and conduct with the Italian humanists 
whose Neo-platonism helped to build the world of matchless form that eradiates from the works of Lionardo, Raffael and Michelangelo.

The strength of German humanism lies in its critical impetus. It cannot be denied that this critical impetus also was not altogether free from blemish. In many cases it ran riot and consequently led to extravagant and fantastic vagaries - one only need to think of such men as Paracelsus or Agrippa of Nettesheim. The popular figure of the sorcerer Faustus is the well-known legendary type of this side of German humanism. Yet, with all these reservations, the fact remains that the German humanists of the sixteenth century, as a whole, have been among the principal forerunners of the modern scientific view of the world.

They based their view of the world upon the intellect instead of the belief. They found their religion in the striving for insight into the reasonableness of the universe. They taught a morality which places the reward of virtue in the feeling of harmony with reason and in work for the enlightenment of humanity. They kindled a light which, although soon to be eclipsed by the dogmatic conflict between Protestantism and Catholicism, has shone into the far distance and has again and again awakened new life. 
The central figure of humanism north of the Alps, and especially of German humanism, at the beginning of the sixteenth century, was Erasmus of Rotterdam. Until Luther shook the world with his first revolutionary manifestoes, Erasmus was the controlling power of German intellectual life. In all German universities where the humanist "poetae" struggled for supremacy against their adversaries the "theologistae," Erasmus' name was the watchword around which the representatives of the new conception of human freedom and human dignity rallied. ${ }^{1}$ The young Tübingen magister artium Philip Melanchthon published in I516 an original poem in Greek " in Erasmum optimum maximum," in which Zeus entertains Apollo and the Muses with the sweet-perfumed flowers of Erasmus' poetry. In a letter of October, I 516, Ulrich von Hutten addressed Erasmus as the German Socrates whom he would like to serve with greater devotion than Alcibiades had shown toward the Greek philosopher. In the same year he designated Erasmus and Reuchlin as the two eyes of Germany: through them, he said, the German people had been wrested from barbarism. As a second Hercules, who had freed the world from the monsters of darkness, Erasmus was greeted in $15 \mathrm{I} 7$

${ }^{1}$ Cf. Paulsen, Gesch. d. gelehrten Unterrichts i, Io2. 
by the Cologne humanist, Caesarius; as a second Paul, who was bringing back genuine Christianity, he was glorified by the Leipzig theologian, Hieronymus Emser. In Nürnberg, the Erasmian ideal of a reconciliation between the Church and classical antiquity found a splendid embodiment in the stately patrician Willibald Pirkheimer. At the University of Erfurt, Eobanus Hessus based his lectures on humanism upon the Erasmian "Handbook of a Christian Soldier." In the circle of the brilliant Mutianus at Gotha, Erasmian toleration and free thought became the spiritual bond of a literary coterie of extraordinary refinement and aristocratic fastidiousness of cultivation. Mutianus himself has said: "Erasmus surpasses the measure of human gifts. He is divine, and must be worshipped in pious devoutness."

This seemingly excessive praise of Erasmus by his contemporaries was after all not undeserved. It rested on the instinctive feeling that Erasmus was the most perfect personal embodiment of the ideals in which the humanists believed.

None of the German humanists represents the intellectual culture of the sixteenth century in as brilliant a manner as Erasmus. None has made freedom of critical investigation so consistently as he the measure of all thinking and acting. None 
has had the same power of creating works of art of universally human significance, on the basis of this strictly intellectual view of life. Erasmus of all men of his time comes nearest the ideal of culture of the eighteenth century. He combines in himself the two seemingly opposed tendencies scepticism and optimism - which in the age of rationalism were to reign supreme in all Europe.

Sceptical observation is the basis of Erasmian wisdom. No authority and no hallowed institution escapes his searching criticism. Everywhere he looks through appearances into the essence of things. With daring courage and subtlest irony he unmasks the selfishness, the vanity, the cruelty, the greed, the laziness, and above all the stupidity which in the ordinary affairs of men hide themselves behind solemn manners, fine words, and brilliant pomp. Nay, all life often appears to Erasmus as one great farce. For men deceive themselves; they really believe to be what they would like to seem; they themselves do not know how absurd they are. Erasmus, however, would rob them of this self-illusion, he would make them spectators of their own folly, he would enable them to have a laugh at themselves.

But the Erasmian laughter is by no means satanic. Erasmus is not a spirit of negation. On the 
contrary, if ever a man believed in the power of mind and in the mission of reason, it was he. In this subtle satirist, this delicately organized, nervously sensitive scholar there lives a firm faith in the final victory of the few enlightened over the stolid ignorance of the mass, there lives a supreme trust in the ultimate redemption of humanity. We may say that nearly all the liberating ideas which make the foundation of the international culture of the present age are to be found, more or less developed, in his thought.

His whole life is pervaded by the thoughts of religious reform which he presented for the first time connectedly in his youthful production "The Handbook of a Christian Soldier," written in I 502; they culminate in the demand for spiritualization and rationalization of ecclesiastical forms. ${ }^{1}$ Reason is for Erasmus " a queen, a divine counselor. Enthroned in her lofty citadel, mindful of her exalted origin she does not admit a thought of baseness or impurity." It is to reason that we must turn to fathom the divine wisdom, it is here that the roots of self-perfection lie. To the unenlightened mind, the Bible remains a labyrinth of contradictions, a book full of insipid and even immoral incidents.

1 For the following cf. Enchiridion Militis Christiani, Lugd. Batav. 164I, pp. 96, I7 I, I73, 145 . 
Through rational interpretation, Erasmus thinks, we learn to understand it as a symbolical expression of moral truths. An unthinking piety is without avail. "Christ," says Erasmus, "despises the eating of his flesh and the drinking of his blood, if it is not taken spiritually. God hates a well fed, corpulent devoutness." But the rational believer sees the working of a divine spirit everywhere, his eye is open to the beauty, the wisdom, the virtue of all ages, he penetrates to the very core of Christianity. "For Christ is nothing else than love, simplicity, patience, purity, in short all that he himself taught; and the devil is nothing but that which draws us away from those ideals."

To teach and to further this "philosophy of Christ," as he called it, i.e., a rational, practical, human, undogmatic Christianity, Erasmus considered the task of his life; from it there spring all the other ideals of his manifold intellectual activity.

More clearly than any of his contemporaries he saw before his eyes the ideal of a religion of man; and the bold conception of an amalgamation between ancient and Christian culture has perhaps nowhere found as touching and genuinely human an expression as in the famous passage of his " $\mathrm{Re}$ ligious Banquet ": ${ }^{1}$ "Surely the first place is due

1 Convivium Religiosum; Colloquia Familiaria, Amstelodami 1679, pp. $128,132$. 
to holy script: but sometimes I find some things said or written by the ancients, by pagans and poets, so chaste, so holy, so divine, that I am persuaded a good genius enlightened them. Certainly, there are many in the communion of saints who are not in our catalogue of saints. I confess, I cannot read Cicero's books on old age, on friendship, on the duties, or his Tusculan disquisitions, without kissing the book, and worshipping the saintly heart which was imbued by divine spirit. And truly, I have never read anything in the ancients which comes nearer Christianity than the words which Socrates addressed to Crito shortly before he drank the poison. This great man did not trust in his own achievements; but since he was conscious of his endeavor to obey God's will, he was inspired by the hope that God, on account of the purity of this endeavor, would accept him in His mercy. Truly, a wonderful elevation of mind for a man who knew neither Christ nor the Scriptures. And thus, when I read such things, I can hardly forego exclaiming: "Sancte Socrates, ora pro nobis.'"

From this toleration and magnanimity of his religious conceptions there emanates, furthermore, the enthusiasm of Erasmus for everything that serves the cause of peace and his.persistent, indefatigable agitation against the uselessness and 
wickedness of war, which has even induced him, in his book on "The Education of a Prince," dedicated to Emperor Charles the Fifth, to propose in so many words the establishment of an international tribunal of arbitration for the settlement of disputes of foreign politics. From the same sense for the reasonable and the useful there emanate his many endeavors for popular enlightenment and popular welfare, his protest against taxing the necessaries of life, and his advocacy of taxing articles of luxury, his demand of reform in public sanitation, his propositions for the prevention of the propagation of sexual diseases, his condemnation of wet-nursing as a danger for the health and purity of the race, his insistence also on the necessity of the higher education of women.

And finally, in this trust in the power of reason and in this conviction of the value of human selfreliance there lies the cause for Erasmus' protest against Luther's doctrine of determinism. Erasmus revolted instinctively against the Augustinian conception that God works the evil as well as the good in us and rewards His own good works in us and punishes His own evil works in us. "How far," he says, " "how far would the door to godlessness be opened to numberless people, if this doctrine, even

${ }_{1}$ De libero arbitrio ed. Walter, Ia ro, IV 5, IV 13. 
if it were true, were proclaimed publicly and universally! What weak man would persist in the constant and hard struggle against the flesh? What evil man would endeavor to reform ? Who could prevail upon himself to love a God who prepared eternal torments of Hell for us in order to make unhappy humanity atone for His own evil deeds? Surely, that would be a cruel and unjust master who would have his slave scourged to death because he was not beautiful enough for him or had a crooked nose or some other bodily defect. Would not the slave be justified to say to his master, 'Why must I be punished for something that I cannot help?" "And Luther and his people seemed to Erasmus to have carried the conception of Original Sin to the extreme of barbarism. "They exaggerate Original Sin above all measure and above all bounds; they try to make us believe that the noblest powers of human nature are so corrupted by it, that we are incapable of anything but misjudging and hating God."

In all this we recognize an extraordinarily free and broad spirit, a man of a serene view of the world who takes life as it is, enjoys its gay and motley scenes, laughs at its vanities and follies, but does not lose for all that his belief in humanity; but on the contrary, again and again, reverts to 
the cultivation of our better self, of the higher nature in us as the sacred concern of life. We recognize in him the mixture of talents and moods which makes the true artist.

Let us see how far Erasmus has succeeded in his two most prominent literary productions "The Praise of Folly" and "The Familiar Colloquies" in creating, from this purely intellectual observation of life, true works of art.

Those critics entirely misunderstand the peculiarity of "The Praise of Folly" who place this brilliant play of humor on the same level with such commonplace invectives as Sebastian Brant's "Ship of Fools" or Murner's " Fools' Meadow." Brant's and Murner's poems are nothing but last off-shoots of medieval popular satire; they are direct attacks against definite defects and abuses of contemporary society; poetic value they have at most here and there in brisk characterization of reality. To be sure, even "The Praise of Folly" contains a wealth of such satirical descriptions of reality and of direct attacks upon definite social conditions; and it is probable that just they found the greatest applause from the contemporaries and have had the largest share in the circulation of the book throughout Europe. Indeed, some of these invectives have such a pungency, such a penetrat- 
ing, merciless truthfulness and such a universally human applicability that even today they are sure of their effect. Not only for the man of the sixteenth century, but for every kind of bigoted churchliness, of whatever time and nationality, is the fiercely ironical judgment which Erasmus pronounces over the stupid saint worship of the great multitude. ${ }^{1}$

"Saints here and saints there, every one for his particular craft and every one with his particular cult. One is good for toothache, another helps women in childbed, a third recovers stolen articles, this one saves from shipwreck, that one protects the cattle - and so on ad infinitum. But what is it that people beg for from all these saints? Nothing but follies. Among all the votary offerings with which the church walls are hung up to the ceiling, have you ever seen a tablet of gratitude for someone's having escaped folly? One has been saved from drowning; another from the dagger of an enemy; a third one has bravely run away from the battlefield; a fourth, through intercession of the patron saint of the thieves, has safely jumped down from the gallows; a fifth has broken out from prison; this one in spite of his physician has recovered from a fever; another has not been killed

1 Moriae Encomium, Lugd. Batav, 1648, pp. $160 \mathrm{ff}$. 
but benefited by the poison given to him by his wife; still another, caught with the wife of another, has successfully outwitted her raging husband all these people hang up their votary tablets. But no one gives thanks for having been cured of folly."

And of equal universality of satire is the bitter comparison of the teaching of Christ and the life of his Vicar at Rome, ${ }^{1}$ a comparison between ideal and reality of social institutions which will be repeated again and again, as long as there are institutions needy of reform. "If the pope, the Vicar of Christ, were to attempt to imitate Christ's life, that is, his poverty, his toil, his teaching, his cross, his scorn of the world, what position in the world would be more dreadful than that of the pope? Who would then still care to buy the holy office with endless treasure or, having bought it, try to maintain it by sword and poison and every violence? What pleasures and joys would the pontiff forego, if he allowed wisdom, nay even a grain of that salt of which Christ speaks, to have access to his court! What wealth, what honors, riches, conquests, taxes, horses, mules, guards and all kinds of luxuries would he lose! And in their place he would have vigils, prayers, fasts, tears, sermons, lectures, and a thousand other painful things. How

${ }^{1}$ Loc. cit., pp. 282 ff. 
many scribes, copyists, notaries, advocates, promoters, money-changers, mule-drivers, grooms, innkeepers and disorderly persons would be driven to starvation! Inhuman and abominable to think of such a thing!"

But deeply penetrating and universal as is the satire of this book, its poetic charm and its intellectual significance consist in something else. "The Praise of Folly," to put it briefly, is the confession of faith of a brilliant free thinker, who looks at life without any constraint or preconceptions, who looks down with a pitying smile upon "the mob of dignitaries and wise men" 1 and before whose capricious and fantastic humor hardly anything except the wholesome, instinctive enjoyment of life stands the test. It is a chapter of romanticism before the romantic period. Friedrich Schlegel and Ludwig Tieck must have delighted in this jolly " fox hunt" against Philistinism.

It was a stroke of genius that Erasmus makes Folly her own advocate, that he makes her propound herself her own topsy-turvy view of the world. For in the first place, he reserved to himself thereby his own final judgment and kept open the way toward his own true ideal of the reign of reason. And then, what is more important, the book gains thereby,

1 Loc. cit., p. 25. 
from the very beginning, an irresistibly dramatic life. From beginning to end, we rejoice in the bold, brilliant paradoxes of the buoyant speaker; we hear the applause with which she is greeted by the large audience as she appears on the platform; and we are satisfied at the end that of all the advices contained in her speech none will be more conscientiously followed by her hearers than the "Vivite, bibite!" "Live, and drink!" with which she leaves the desk.

"Do not take, ye men" - thus the serene wisdom of this graceful and eloquent lady, a feminine forerunner of Bernard Shaw, might perhaps be paraphrased - "do not take life so hopelessly seriously and deliberately. What is it after all but one long, divinely foolish intoxication? I, myself, the protectress and benefactress of humankind, have descended from the Happy Isles. Not as the tiresome and prudish Athene have I sprung from the brain of my father; no, I am a child of love's frenzy; laughing have I come into the world and my parents were Riches and Youth. And the same is true of the origin of all true life. Not thought and reflection, but instinct and desire lead to propagation; for what man would, on serious reflection, take upon himself the fetters of marriage, and what girl the pains of motherdom? 
Nay, as much as they would like to deny it, even gray-bearded philosophers and decrepit monks, even king and emperor, and bishop and pope, owe their origin to the intoxication of a moment. And all the joys which life offers come from the same source. Why does all the world delight in a child's face, why do we fondle and caress and kiss the little ones, but because they don't know anything ? What is more repellent and disagreeable than a precocious and overwise child? Wherein consists the charm of youth but in this, that it lives from day to day without thought and care? And whence come the furrows, the dragging gait and the sour mien of riper age than from this, that thinking makes the blood sluggish and the limbs lagging ? Thanks, therefore, to me, to Divine Folly, that in old age I lead men back to the Fountain of Youth and in oblivion bestow on them a new life.

But even in the midst of the cares and duties of middle life, it is I who make life at least to some extent tolerable. For fortunately, man is only in small part intellect and in by far the greatest part instinct and feeling; and thus he tries over and over again to sweeten the dreariness of life through some blind caprice, some outright folly. Does not love bless us just because it makes us blind ? Do 
we not seek in wine oblivion from the platitudes of work-a-day life? Does not friendship paint even the defects of our friends as virtues? And are not all our hobbies a sort of spleen? Are we not proud of our own foibles, errors and prejudices? Are we not fond of deceiving ourselves by attributing to our actions fine motives, by representing our ambition as sense of duty, our desire for glory as patriotism? But just in all these illusions there rests our true happiness; and all the great things that are done proceed from them.

What could be more useless and delirious than war? The very things which it wants to accomplish, the blessings of peace, it destroys. And yet war has rightly been called the father of all things. For it fans the great passions, it gives birth to the great deeds of history, it creates the great men who do not reflect long whether they are to act thus or thus, but who like Quintus Curtius, following the phantom of glory, with quick resolution jump into the chasm. And as in war so it goes in public life at large. Plato was wrong when he wanted to entrust the conduct of state to the philosophers. Not the wise man but the ignorant is the born leader of the masses, the man of quick decision and of happy instinct, who knows how to get on with everybody, is himself no paragon of virtue and 
does not expect much from others, but trusts in himself and his luck.

In short, the less burdened by thought, the lighter, gayer and more beautiful is life. The more we follow only our instinct, the more we approach the Golden Age, the happy state of nature. ${ }^{1}$ And perhaps - here Erasmus takes a sudden mystic turn - perhaps this is also the only way in which we can penetrate into the mysteries of the divine. For the divine is not to be reached by logic; the sterile scholasticism of our theologians proves this sufficiently. In order to grasp the eternal, the invisible, the spiritual, man must be driven by holy madness. The chosen few to whom this is given are as it were beside themselves, they rage like lovers, they weep and laugh, are jubilant and downcast, fume and storm, until at last they are so entirely out of their senses, that they give themselves up wholly to the divine in inexpressible bliss. ${ }^{2}$ And this, then, is a small foretaste of the future heavenly joys.

Thus, then, through the whole book there runs as a fundamental thought the contrast between the dry and inadequate intellect and the creative power and infinite changeability of imagination. On the

1 Loc. cit., pp. 120, 125.

2 Loc. cit., pp. 347 f. 
one hand, conscious calculation and fruitless labor, on the other uilconscious instinct and happy enjoyment. On the one hand, perversity and artificiality, on the other full and free nature. On the one hand the learned pedant, the heartless philistine, the kill-joy, the hypocritical formalist, the self-righteous, friendless, stone-cold, inhuman paragon of virtue; ${ }^{1}$ on the other the light-hearted artist, the joyous companion, the good comrade, the bold hero, the inspired enthusiast, the amiable man of feeling, who abhors no human weakness and no human folly.

It is proof of the extraordinary breadth of Erasmus' view, that he, the apostle of reason, the representative of a rationalistic philosophy, should at the same time have possessed so open a mind for the insufficiency of an exclusively intellectual culture; that he, whose whole activity of enlightenment so often reminds us of Voltaire, should at the same time have formed a conception of the world which in its artistic romanticism foreshadows the nature cult of Rousseau.

Predominantly rationalistic and of unmistakably didactic tendency is the other literary master-

1 Marmoreum hominis simulacrum, stupidum et ab omni prorsus humano sensu alienum; loc. cit., p. 106. 
piece of Erasmus, "The Familiar Colloquies," that collection of varied scenes from every day life in dialogue form, which the author began at the end of the fifteenth century, but brought to a conclusion only at the beginning of the twenties of the sixteenth. It is curious that this book, which appeared down into the nineteenth century in ever new editions and exerted an extraordinary influence throughout Europe, should have become almost unknown to our own time. For it contains the ripest fruit of Erasmus' clear, serene view of life and shows him not infrequently as a master of literary art. Indeed, one gains in these Erasmian colloquies a picture of the sixteenth century so comprehensive, so variegated, so intimate, so sharply drawn, lighted up by such delightful humor, enlivened by such noble sentiment, as in hardly any other work of the time.

In part they are mere genre pictures, descriptions of manners without obvious spiritual tendencies, but just in them the Erasmian humor is most apparent. How delightful, for instance, is the scene from school life, ${ }^{1}$ in which the playful boys beg of their morose teacher to give them a holiday, because the weather is so fine. How humorous is the description of the doings in German inns; ${ }^{2}$ the

1 Lusus pueriles; Colloquia Familiaria, Amstelodani, r679, pp. $39 \mathrm{ff}$.

2 Diversoria; loc. cit., pp. $214 \mathrm{ff}$. 
surly porter, who at the arrival of a stranger puts his head out of the window, as the turtle from its shell, and without answering the demand for a lodging points with the hand toward the stable, in which every one must put up his own horse; the stuffy living room in which riders and pedestrians, merchants and skippers, teamsters and peasants, women and children, healthy and sick, crowd one another, each one attending to his own needs and in which, although the air through overheating and smells is intolerable, yet by no means a window must be opened; the long, dirty tables set with wooden plates and wooden spoons, at which one must sit forever and wait until the miserable evening meal and the sour home-grown wine are served; the infernal noise which is set up, after the supper, by the drunken company; the Jack who silently goes from table to table, chalking off on each the bill according to the number of guests sitting there, and just as silently taking in the cash; - all this could not be described in a more graphic or droll manner.

Particularly happy is Erasmus, whenever he combines with this description of real life humorous traits from the traditional popular tales, as for instance, in the "Apparition," the delightful jokes which a jolly fellow plays on the superstition 
of an ignorant priest believing in ghosts; or the "Horse Dealer," the merry story of the shrewd tricks by which a man deceived at a horse deal succeeds - like David Harum - in working off the worthless nag on the deceitful seller at double the price he had given for it.

In both dialogues the manner in which Erasmus transports us at once into the action is remarkably vivid. In the "Apparition," one of the two characters says: " "You know the farmer, Soand-so, the great rogue, and his farm near London ?" "Certainly, I have often enough had a glass with him." "Then you remember the highroad near by with the two long straight rows of trees?" "Certainly, two gun-shot from the left of the house." " Just so, and on one side of the high-road is a ditch, overgrown with thorns and bushes, and across the ditch there leads a small bridge upon a path into the field." That now is the place where the ghost is said to have appeared, and in the whole following account the scenery as well as the main character of the action stand most distinctly before our eyes. And perhaps still more original is the setting of the other tale. ${ }^{2}$ Two friends meet and one of them says: "Why so sober

1 Exorcismus sive Spectrum; loc. cit., p. 292.

2 Hippoplanus; loc. cit., p. 309. 
and solemn ?" "I'm just coming from confession." "Then you have reeled off all your sins ?" "All except one." "Why not that one ?" "Because I'm so much in love with it." "That must be a charming sin." "I don't know whether it is a sin or not." And now he tells the tale, how he paid back the deceitful horse dealer in his own coin; and at the end the friend declares him not only not guilty, but thinks that his cleverness is worthy of a monument.

The true essence, however, of the Erasmian "Colloquies" does after all not lie in their masterly and sure representation of reality, but in the enlightened, free, genuinely human spirit which animates them. In the preface to the edition of I 526, Erasmus defends himself against the accusation that his "Colloquies" undermine morality and the belief in God. And, indeed, nothing is more unjust than this accusation, which was raised by the Sorbonne as well as Luther and many other zealots of his time. To be sure, of prudishness or respect for established prejudices there is not a trace in this book. Erasmus calls things by their names; he drags crimes, sins and foulness of all sorts out into the light of day; he cannot resist pouring the vials of his irony over stupidity and mediocrity. But again and again there appears, 
as the fundamental tendency of these varied pictures of life, the honest endeavor to widen the horizon, to heighten the sense of true greatness, to awaken sympathy with genuine piety, to promote tolerance, peaceableness, self-control, industry, pure conduct, innocent enjoyment, trust in the wisdom and beneficence of Providence. And here and there at least this ideal of humanity finds a truly remarkable artistic expression.

Seldom has monastic life been represented so attractively or been embodied in so fine and human a character as in the dialogue between the Carthusian monk and the soldier. ${ }^{1}$ Set off against the barbarous trade of war, with its endless knocking about, its brutalities and excesses, the monastery appears here as an abode of peace and spiritual culture. The Carthusian has not plunged into it recklessly and headlong as into a fountain, but after he had come to know the world and scrutinized himself, he has entered it. And now he feels there completely happy. "This place is to me the world," he says, "and from here I may roam in thought over the whole globe, and travel more comfortably and safely than those who sail after the newly discovered isles. And as to loneliness of which you speak - well, even the prophets, the 1 Militis et Carthusiani Dialogus; loc. cit., pp. $193 \mathrm{ff}$. 
philosophers, the poets, indeed, all men who ever undertook anything great and above the ordinary, retired from the crowd into solitude. And besides, I have here in my brethren as much opportunity for intercourse as I want, and above all, the best company in my books." "But you in the monastery," answers the soldier, "place too much value in prayers, garments, fastings and ceremonies." "It is not for me," says the monk, " to judge what others do; as for myself, I put no value in these ceremonies, but trust alone in the purity of the soul and in Christ." Now the conversation turns toward the military trade, and again the enlightened mind of the friar reveals itself. He asks the soldier how he could have justified to himself leaving his young wife and children and stooping, for miserable pay, to pillage and murder his fellow men. "It is right to kill our enemies," says the soldier. "Perhaps then," answers the Carthusian, "when he attacks your country. Then it may appear pious to fight for wife and children, for parents and friends, for altar and hearth, for the peace of the state. But what has that to do with your mercenary trade? If you had been killed in this war, I shouldn't have given a rotten nut to save your soul."

If in this colloquy the magnanimity of Erasmus even toward the representatives of the old church 
is shown, provided they evince an honest endeavor for spiritual independence, he draws in another dialogue, entitled "The Funeral," 1 an extraordinarily bold and artistically complete picture of the stupidity, greed and hypocrisy of the ruling churchdom, contrasting with it the noble humanity of his own belief.

The subject is the death bed and the funeral of two very different men. The one is a former captain of mercenaries, who has amassed a pretty fortune in war, is entirely correct in church matters, and therefore belongs to the pillars of society. Now he is dying. The physicians have given him up, but are still carrying on a heated dispute, in the death chamber, over the diagnosis of the disease, and finally force the patient to consent that there shall be an autopsy. Now the physicians are replaced by the clergy, who press around the bed in large numbers. They, too, get at once into conflict with each other, like vultures gathering around the carcass. A horrible scene is now enacted. No attention is paid to the dying man or his family; the only concern of these holy men is to squeeze out of him as much as possible. In the first place, the local priest and the begging friars have a squabble. The priest insists that the dying, who has just con-

I. Funus; loc. cit., pp. 439 ff. 
fessed to the friars, should again confess to him; he is treated for this by his rivals to the vilest insults, and pays them back with like defamations. Finally, the patient puts a stop to the loathsome altercation by promising the priest to pay in advance all the fees for the last sacramental rites, the tolling of the bell and the funeral. Scarcely has this been settled, when a still wilder dispute arises between the individual orders; for now it is the question of the will, and every one of the five orders wants of course to snap up the fattest portion. Again there ensue the most violent accusations and counter-accusations, the most miserable haggling and bargaining, and again the patient must beg for peace, and satisfy the shameless greed of the holy men by submitting to all their demands. His own family fare worst in the will; all five orders are well provided for; most bountifully, however, the Franciscans and Dominicans. Now the arrangements for the funeral are made, and again there arise exhilarating discussions about precedence and rank of the individual orders and clericals in the procession. Then the pompous monument, which is to be erected to the noble lord, is arranged for in detail. And now at last he may die, but even that not undisturbed. He is clothed in a monk's cowl; and while he is lying in his last gasps, a Fran- 
ciscan shouts into his right ear and a Dominican into the left.

How died the other man whom this dialogue depicts? He died as he lived, without ado and without giving any one any trouble. Years ago he had made his will; legacies for monasteries and churches there were none. "For," he used to say, "I've given as much in my life-time to public charities as was in my power. And now that I leave my property to my people, I leave to them also the disposal thereof, and hope that they will make a better use of it than I have done." No priest attended him in his dying hour (confession and last unction had been performed a few days before); only his family and two trusted friends were at his side. He had refused tolling of bells and solemn funeral. With simple words he took leave from his wife and children. "If you should marry again, my beloved wife," he said - at these words the wife broke into tears and vowed that she would never think of it; but he continued, and assured her that she should not consider herself bound to him under all circumstances; only she should not forget what duties she had for her children, and especially she should see to it that the children would not choose too early a definite calling, but wait until they were experienced 
enough to make a really suitable decision. Then he kissed wife and children, prayed for them, made the sign of the cross over them, and commended them to the mercy of Christ. At four o'clock in the morning he had a psalm read to him and asked for cross and candle. And after he had taken the candle in his hand and kissed the cross, he laid his hands over his breast in prayer and said, his eyes raised to heaven, "Lord Jesus, receive my spirit." And he closed his eyes and went to sleep.

Finally, a scene from the "Apotheosis of Reuchlin," 1 the dialogue in which Erasmus vies with the art of a Memlinc or Bouts in the representation of a heavenly idyll, but at the same time embodies his own ideals of free and fearless inquiry in the character of his humanist friend and fellow soldier.

For some time they have known in Tuebingen that the old scholar is ill, and one fears for his life. Then a pious Franciscan in the town at early morning after the matin has the following dream. "It seemed to me," he says, "I was standing by a bridge, which led to a wondrous meadow. Leaves and grass shone in emerald green. The flowers sparkled like stars. Everything exhaled fragrance round about. And the fields this side of the brook which separated me from the meadow seemed dead

${ }^{1}$ Apotheosis Capnionis; loc. cit., pp. $147 \mathrm{ff}$. 
and withered in comparison. While I was still lost in this glory, Reuchlin passed by me, and offered me greetings in Hebrew. ${ }^{1}$ He had already passed the middle of the bridge, when I noticed him; and when I wanted to hasten after him, he bade me remain. 'Not yet,' he said. 'Five years from now, follow me. Meanwhile remain here as spectator and witness of what happens.' He wore a white garment, strangely translucent, and a charming boy with wings followed him. But behind him at a distance there hopped black birds like magpies, but as large as vultures, with feathered tufts on their heads and with crooked beaks and claws, and fat bellies. ${ }^{2}$ They cawed and screamed at the sturdy knight, Reuchlin, and feigned to attack him. But he turned around toward them and made the sign of the cross and spoke: ' Get ye hence, ye ugly monsters. Off with you where you belong. You have enough to do on earth, your rage has no power over me here in eternity.' Scarcely had he said this, when the ugly birds flew away, leaving a frightful stench behind them. But already Saint Jerome ${ }^{3}$ approached the bridge and greeted

1 The language to the study of which he had devoted his life.

2 Types of the monkish detractors and enemies of Reuchlin.

3 Reuchlin's forerunner and intellectual associate in biblical editorship. 
Reuchlin with the words: 'Welcome, saintly companion. I am commissioned to lead you into the heavenly dwellings of the blessed, which the goodness of God has ordained for you as a reward for your pious endeavors.' The whole field swarmed with myriads of angels, who filled the air like sunbeams. Jerome embraced Reuchlin and led him to a hill in the middle of the meadow. On the summit of the hill they kissed each other, and then the heavens opened above their heads in boundless distance, and an inexpressible glory floated down, like a mighty transparent column of fire. In it the two saints, embracing each other, ascended to heaven, and the angels sang together." "So then," exclaim the friends in whose circle this vision is told, "so then let us receive the great man into our calendar of saints. Let us place him in the chapel next to the most illustrious of the martyrs. In the service of science he has suffered many persecutions from evil men and hypocritical scribes, but now he is reaping the fruits of the seed which he has sown. His death we cannot bemoan; for he has left us precious monuments of his life, and his works have dedicated his name to immortality."

May we not apply these words to Erasmus himself ? May we not say of him that in his "Praise of Folly" and in the "Familiar Colloquies" he 


\section{ERASMUS}

has left us works of art, of truly liberating, purifying power? Works of art which will retain their value, as long as there is any need of continuing the warfare for a rational view of the world and for a society worthy of mankind. 


\section{CHAPTER VI}

THE HUMANIST REVOLT: ULRICH VON HUTTEN

D ECENT German criticism is inclined to unRervalue the services rendered by Ulrich von Hutten to the cause of German culture. Friedrich Paulsen in his " History of Higher Education in Germany" calls Hutten's whole humanist propaganda a bombastic masquerade. ${ }^{1}$ Friedrich von Bezold in his " History of the Reformation" dismisses Hutten's plan for a reorganization of Church and State as fantastic dreams. ${ }^{2}$ And nearly every writer on Luther and his work contrasts with the deep and invincible faith of the Wittenberg monk and his irresistible pressing on from fight to fight the wayward, meteoric and fruitless career of the unbelieving and sceptical partisan of humanism.

It is my purpose to vindicate Hutten's activity, to show that his political ideals were by no means intrinsically unconstructive and that, if he failed in his work, if his cause was vanquished, there might be said of him what the ancient poet said

1 Geschichte des gelehrten Unterrichts i, pp. $86 \mathrm{ff}$.

${ }^{2}$ Geschichte der deutschen Reformation, pp. $284 \mathrm{ff}$. 
of the unsuccessful opponent of Caesar: "Victrix causa Deis placuit, sed victa Catoni."

In Ulrich von Hutten's personality German humanism gains its most ravishing and irresistible expression; in him the Erasmian enlightenment turns into a revolutionary power, which shakes the foundations of existence. They misjudge Hutten's innermost being, who consider him above all as an ally of the Lutheran reformation. Hutten himself saw in Luther the ally and champion of his own humanist cause; he saw in him the destroyer of hierarchy, the deliverer of the German people from the Romish yoke. He would have been the last to submit to a new religious dogma as preached by the Wittenberg party. His aim was the political and intellectual reconstruction of Germany. Abolition of the monasteries, confiscation of church property, secularization of the schools and the higher institutions of learning, safe-guarding of free thought and free inquiry, centralization of the empire, limitation of the power of the territorial princes, utilization of the knighthood and the citizen class for the formation of a powerful German army - these were the practical ideals which fired his reformatory passion. Perhaps these thoughts were doomed from the beginning to remain unrealized. Perhaps the centrifugal development of Germany 
during the preceding centuries had made a radical reconstruction of the imperial power impossible. Perhaps the German masses were not yet ripe for the adoption of a rationalistic view of life, although Zwingli's reformatory activity in Switzerland has been a valid testimony to the capacity of humanism even for ecclesiastical organization. Perhaps the German knighthood was the least fitting instrument of national rejuvenation. And, surely, all these plans were wrecked by the fact that of the two German emperors of Hutten's time the fantastic Maximilian lacked the power, and the unGerman Charles the Fifth the least disposition to carry them through. But are they on that account less remarkable or less worthy of the admiration of a posterity which has seen their fulfillment, not to be sure in the form which Hutten hoped for ? Hutten remains in spite of all his errors and defects one of Germany's heroes. It remains a pathetic story how this man, thrust out a mere boy into a friendless world, tossed about in poverty, toil, and youthful excesses, early afflicted and tortured for years by a hideous disease, placed entirely upon his own resources, driven about in fruitless struggles and adventures, - steadfastly adheres to his ideals of country and liberty, preaches for them with flaming eloquence, works with restless activity for 
their realization, is never for a moment doubtful of himself, dedicates himself unreservedly to his cause, and finally at thirty-five years of age physically exhausted and politically annihilated, but inwardly unbroken, meets death in exile. And it remains an honor to Zwingli that, while Erasmus as well as Luther finally shook off the impetuous and uncompromising fighter, the Swiss reformer was large-minded enough to offer him, as a soldier of freedom, a last refuge.

Hutten has expressed himself about his practical relations to life perhaps most emphatically in two letters to friends - the letter with which in $\mathrm{I}_{5} \mathrm{I}_{4} \mathrm{he}$ sends to Crotus Rubeanus, the principal author of the "Epistolae Obscurorum Virorum," his humorous poem "Nemo" (The Nobody); and the letter of October, $\mathrm{I}_{5} \mathrm{I} 8$, to the Nürnberg patrician and humanist, Willibald Pirkheimer, in which he justifies himself for his accepting a position at the court of the archbishop of Mainz.

In the former letter ${ }^{1}$ Hutten appears as the champion of a free, entirely unrestrained literary life. It had been the impulse for spiritual independence, for struggle with fate, for adventurous tests of power and for a full living out of himself, which had driven the sixteen-year old youth to

1 Hutteni Opera ed. Böcking i, 175 ff. 
flight from the cloister-school in Fulda, and then to vagrant journeyings from one German and Italian university to another, and finally into service in the imperial army in Italy. Without having brought his studies to a conclusion, without title and office, full of contempt for theological and legal pseudoscience, full of enthusiasm for the humanist ideals of life, he had, in I $^{1} 4$, returned home. Instead of being welcomed after so long an absence, he relates to Crotus, he was treated by his family as a degenerate, as a man who had wasted his time and not accomplished anything, as a "Nothing," a "Nobody." These mocking designations Hutten accepts as a title of honor. "Yes," he says, "if to be something means to acquire a degree of master or doctor, if you are nothing until you stoop to take part in the farce of learned nonsense, if it is not a question what kind of a man you are but whether you have learned the tricks of rabulistic perverters of law, or the hair-splitting dialectics of hypocritical theologians, then I will rather not have learned anything, I will rather remain a "Nothing" and a "Nobody." For a man proves himself in the struggle with life and in the free service of the muses; and nothing shall induce me to swerve a hair's breadth from the striving after this genuine humanity, unfalsified by empty formulas and hollow names." 
If this letter reveals the Faust-like craving of the Renaissance man for free individuality, we recognize in the letter to Pirkheimer ${ }^{1}$ the other side of Hutten: his passionate desire to accomplish something worthy, for humanity and above all for his country. In the meantime he had gained opportunity for activity on a larger scale as well as recognition from his sympathizers. Against the foreign enemies of the empire, especially Venice, France, and the Pope, he had sounded a call in his epigrams addressed to Emperor Maximilian. He had attacked in weighty philippics the Duke Ulrich of Wuertemberg, the murderer of his own cousin, Hans von Hutten, as a disturber of the inner peace, and had appealed especially to the knighthood to help in annihilating the "tyrant." He had contributed his share to Crotus' "Epistolae Obscurorum Virorum,"2 and here he had contrasted with monkish stupidity and sloth his ideals of free and enlightened humanism. By editing Lorenzo Valla's "Constantine Donation," and by its ironical dedication to Leo $\mathrm{X}$, he had, in $\mathrm{I}_{517} 7$, struck his first great blow against the papacy. He himself had in the same year at Augsburg been crowned poet laureate by Emperor Maximilian, had then

1 Loc. cit., pp. 195 ff.

2 Namely the Appendix to the first part and all of the second part. 
entered the service of the liberal-minded archbishop of Mainz and had prepared for the Augsburg diet of 1518 a flaming address in which he exhorted the German princes to unity and to the granting of means for a war against the Turks. All these things re-echo in the letter to his friend Pirkheimer of October, ${ }^{1} 5^{18}$, in which he justifies himself for his entering politics and court life. It is clear from this letter: Hutten now feels himself a public leader, a representative of Germany, a champion of national culture, honor, and freedom. He recalls to mind Pirkheimer's own example, his many-sided public activity, the highly developed public life of his native town, Nürnberg, which, Hutten says, had led not only to the highest development of industry and commerce, but had also offered room for the scientific and literary endeavors of a Regiomontanus and Celtes and for the brilliant creations of the German Apelles as he called him: Albrecht Dürer. What Pirkheimer and his like had done for the cities he, Hutten, - so he answers Pirkheimer - was trying to do for his own class, the knighthood. The knighthood, he tells us, unfortunately, still lacked the consciousness of its high, spiritual tasks, it was entirely absorbed in economic struggles and petty feuds. Therefore, it was his ambition to make 
clear to his class that true nobility must be acquired by service, and to give them in himself an example of genuine class honor and of knightly championship of national affairs. "May it fare ill with me, Willibald, if I think myself a noble unless I have made myself so by work. And let me not be contented with what I have inherited from my ancestors, but let me add something to it which by me will be bequeathed to posterity." 1 The time is ripe, he thinks; not a few of the princes are inclined to further the new culture. Through entering their services, the nobility might again become a power for progress. For him personally such a practical participation in the affairs of public life is an inner necessity. He has not yet tamed himself, not yet calmed his youthful fire, not yet done enough to give himself over to scholarly leisure. But even in the unrest and the distractions of court life he will never cease to belong to himself. "I shall always be Hutten and never be found a traitor to myself." Never will he allow fate the control of his soul, always will he consider the

1 Ut non ex imaginariis illis nobilibus tantum censear aut eo quod a maioribus meis accepi contentus sim, verum aliquid ad istas dotes quod a me in posteros proficiscatur adiecisse videar; loc. cit., p. 208. The parallelism between these words and Goethe's

Was du ererbt von deinen Vätern hast

is obvious.

Erwirb es um es zu besitzen 
struggle for humanism as the sacred concern of the time and call himself happy that he has been chosen to take part in the struggle. "O century, $\mathrm{O}$ arts, it is a joy to live and not to rest, my Willibald. The studies are flourishing, the spirit is awake. Barbarism, accept the yoke and submit to exile!"

Since the days of Walther von der Vogelweide no German had proclaimed as emphatically as Hutten did in these two letters, the union of spiritual independence with unselfish devotion to the cause of country as the ideal of manly activity. During the five years which now were left to him he endeavored with restless energy and with heroic exertion of his whole personality to realize this ideal and to make it, as far as lay in his power, a means of destruction of medieval theocracy and to found on it a new German public consciousness. These five years from 1519 to 1523 contain the writings of Hutten which show him at his height and associate him with the greatest German publicists of all times.

When we recall what Hutten in these years experienced, planned, strove for and, accomplished we cannot escape, quite apart from the cause which he represents, the impression of human greatness. 
The mere extent and range of his activity during these years is astounding, all the more so when we remember that the curse of his life, the frightful disease to which he finally was to succumb in spite of transient and apparent recovery, continued to prey upon him during this whole time, constantly broke out afresh, and again and again prostrated him. In the spring of I $_{5} \mathrm{I} 9$, he exchanges court life once more for his inherited knightly craft; he takes part in the expedition of the Swabian alliance against his old foe, Duke Ulrich of Wuertemberg. Then he settles for a few months in his ancestral castle, Steckelberg, establishes there his own printing press and sends out from there his last philippics against Ulrich, which instinctively turn into a pæan of victory over the hated tyrant, at last defeated. In April, 1520, he publishes that first collection of martial dialogues in which, anticipating Luther's revolutionary manifestoes by several months, he incites the German laity to a complete break with Rome and to extinction of the whole clerical system. In June of the same year, he goes to Brussels in order to win Archduke Ferdinand, the brother of Charles the Fifth, for his plans of nationalizing the German church. Without having found a hearing, he must take leave. On the home journey, he learns that a papal edict has been sent 
against him in which his former master, the Archbishop of Mainz, is requested to proceed against him on account of his " scandalous machinations." Then he accepts the refuge which his friend, Franz von Sickingen, offers him in his castle, the Ebernburg near Kreuznach, and from this "shelter of justice " he displays again, during the last third of 1520 and the larger part of 1521 , the most intensely revolutionary propaganda. He turns to Emperor Charles and adjures him to stop the papal insolence; he turns to the Elector, Frederick the Wise of Saxony and admonishes him of his duty at the head of the German princes to succor the country's freedom and welfare; he turns to Germans of all classes and calls upon them "to drive from the country the godless pardon-mongers, the impious dealers in dispensations, absolutions and all sorts of bulls, who had turned the holy church of God into a grocery shop." He edits the papal bull against Luther with ironical comments; in a poetical lamentation over the burning of Luther's writings at Mainz, the earliest of his German poems, he addresses Luther as his "dearest brother" and places himself life and limb at his disposal. In the "Lament and Exhortation against the excessive un-Christian Power of the Bishop of Rome and the unministerial Ministers," he calls upon his coun- 
trymen to take to arms. He translates his Latin dialogues into German and adds to them pithy and stirring prefatory verses; and at the same time he publishes a new series of warlike dialogues, in spite of their Latin form of truly popular power. He follows from Sickingen's castle the Diet of Worms with feverish interest, he sends to Luther words of unreserved admiration and assurances of unqualified faith ("My affairs are human, you dwell entirely in the divine,"); ${ }^{1}$ he hurls invectives against the papal delegates, against the cardinals, bishops and abbots assembled in Worms, and addresses patriotic exhortations to the Emperor. And finally, when the imperial edict against Luther has been issued, he seeks a last means for saving the country in an offensive alliance of the knighthood and the cities. In the fatal campaign of Sickingen's against the Archbishop of Treves, which in $\mathbf{I}_{522}$ leads to the breakdown of all of Hutten's hopes and plans, we lose trace of him, until he reappears as a fugitive in Switzerland. But even the hunted and exhausted fugitive rallies, in the controversy with Erasmus, to a last passage at arms for the Lutheran cause, and the dying one gives to his people in the resuscitated figure of Arminius, the destroyer of the Roman legions in the Teutoburg Forest, a new national hero.

1 Loc. cil., ii, 55 . 
The keynote of all these war manifestoes is a boundless, imperturbable trust in the cause of truth, and the unbending will to carry it to victory or to die for it. It was no mere phrase when from the Ebernburg he writes to the Elector of Saxony: ${ }^{1}$ "Would to God that either you (the princes) who have the power had the will, or I had the power, as I have the will. But if I cannot move you nor elsewhere stir a fire, I shall at least do what I can accomplish alone. I shall do nothing unworthy of a brave knight, I shall never, as long as I have my senses, swerve one step from my undertaking; you, however, if I should see you deviate from manly firmness, I shall pity. I can die, but I cannot be a slave, nor can I see Germany enslaved. I hope the best from you; therefore I have written to you a freeman to a freeman. Farewell and be a man." His own ideal of a man he has expressed in the "New Year's Wishes" with which he sends his German dialogues to Franz von Sickingen:" "And I wish you, not as we often wish our friends, an agreeable and enjoyable leisure, but plenty of serious, hard, and strenuous work, by which, for the benefit of the many, you may exercise and test your own proud and heroic mind." And from his

1 Loc. cit., i, $398 \mathrm{f}$.

2 Loc. cit., i, 449 . 
innermost heart there came the thrilling words with which he introduces these dialogues to the reader: ${ }^{1}$ glorying in the rebirth of truth; consecrating himself to its defence; defying all the powers of darkness, papal excommunication and imperial proscription; asking God's blessing for his pious mother in her care and anxiety for his fate; and winding up with the exultant " Ich hab's gewagt!"

Hutten's was not a deep or a speculative nature. All mysticism, all religious fervor were foreign to him. Not like the great medieval mystics, not like Luther, did he want to serve the cause of God; but, like the ancients, he wished to accomplish great things and thereby leave his name to posterity. But that he was thoroughly in earnest in his attempt to make rationalism the basis of life, that he hoped from the victory of humanism the dawn of a new era of national culture for his fatherland, and longed for it with the whole glow of his passionate soul, words like those quoted are a sufficient proof, even apart from his whole life entirely devoted to this one idea.

And must we not admit that Hutten was indeed the representative of a higher culture? Apart from Crotus' "Epistolae," Erasmus' "Colloquies"

1 Loc. cit., 450. 
and Luther's manifestoes and hymns, what has German literature produced in those first hopeful years of the Reformation that reveals such inner strength and truthfulness, such a wide horizon, such a free sweep of artistic form as Hutten's Dialogues? Among the whole mass of polemics called forth through Luther's first stand against Rome nothing comes near them. To be sure, a fresh breath of wholesome life goes through the polemic dramas of a Pamphilus Gengenbach and Niklas Manuel. Certainly, the flood of peasant and bourgeois pasquils and satire let loose by the struggle against Rome has something overpowering in its elementary fury and recklessness. And even the principal leaders of the Romish party, such as Thomas Murner or Hieronymus Emser, did by no means lack power of persuasion and honesty of conviction. But how crude and uncouth on the one hand, how limited and reactionary on the other does all this appear when we contrast it with the sharply chiselled form and the free grand spirit of Hutten's Dialogues. Here, indeed, there is a man who, like Erasmus, has assimilated the best of ancient culture, the high conception of human dignity, but who is not, like Erasmus, content to cultivate and spread this spiritual refinement but is driven by the impulse to rejuvenate 
and reconstruct thereby the whole order of society. Justly David Friedrich Strauss has pointed out ${ }^{1}$ that it is this youthful impulse of reform which so emphatically distinguishes Hutten's Dialogues from their formal prototype, the dialogues of the brilliant, but cool and blasé Lucian. At the same time, in spite of all his zeal for the common cause, Hutten remains a brilliant artist, a proclaimer of individual genius, and just hereby he lifts himself above the limitations of his subject and above the time to which he speaks; just hereby, he associates himself, like Erasmus, with the few of his age who speak to us also.

If Hutten had not written anything except " The Spectators," "The Bull Killer" and " The Robbers," these three dialogues would be sufficient to secure him a name among the classics of German literature. Who could read these little masterpieces of dialogue without feeling transported by them to the heights of free humanity, and lifted above all meanness, pettiness and artificial distortion? Who will not admit that here polemics against what is evil and doomed to destruction turns at the same time into a serene picture of the world and of a wholesome and hopeful life?

1 Gesprdche von Ulrich von Hulten, libersetzt von D. F. Strauss, p. 5 . 
Delightful is the free and unconcerned manner with which, in "The Spectators," 1 the two divine aviators Sol and Phaethon, who from the height of their day's journey through the heavens look down upon earth, converse with each other about the struggles and joys of the small world of men that swarms far beneath them. It is the time of the Augsburg Diet of 1518 , and the divine charioteers have just arrived over the old imperial town. How they crowd and jostle down below, how they push back and forth, draw hither and thither! What a noise, what a carousing, what a prattling and prancing! Sol instructs his inquisitive son: "It is the Germans; they cannot carry on politics or any public business without banquets and drinking bouts. To be sure, there are some sober people among them (Hutten means himself and his followers); men who hold themselves in control, drink water, cultivate their minds, and take serious things seriously; may they succeed in making themselves felt, for their country's good; but the mass, princes as well as knights and populace, are unfortunately still in the fetters of their inherited and besetting sin, of which Tacitus related long ago - ' Excess in eating and drinking;' and just the best and freest among them, the Saxons, are

1 Opera ed. Böcking iv, 270 ff. 
the worst topers of all. But otherwise the Germans are a splendid people, true, brave, honest and joyous." "But what is the cause of the concourse below in Augsburg?" Phaethon asks. "They are conducting the papal legate, Cardinal Cajetan, in solemn procession to the city hall. He has been sent across the Alps to fool the Germans, has all his sacks full of indulgences, and hopes to bring them back to Rome filled with German gold." "How long is the Pope going to carry on this shameful game?" "Until the Germans who till now he has led by the nose have come to their senses." "Is the time near when the Germans will have come to their senses?" "Very near; for this Cardinal will be the first one who comes home with empty sacks, to the great terror of the Holy City, where they never would have believed that the barbarians would have been so bold." " Are the Germans then barbarians ?" "According to the judgment of the Romans, yes. But if you look upon good manners and friendly intercourse, upon zeal in all virtues, upon constancy and honesty of mind, then the Germans are the most cultivated of all people and the Romans the most hopeless of barbarians. For they have been corrupted by luxury and debauchery and you find with them faithlessness, more than feminine fickleness, deceit 
and villainy as nowhere else." "I like what you say of the Germans, if they only were not such topers." The further course of the dialogue, which now goes on to enlarge on the political and social conditions of Germany, is interrupted by the Cardinal Cajetan himself, who in great excitement and full of wrath shouts up to them from the procession. He calls upon Sol, who thus far had only glanced through the clouds, that he should scatter the clouds and at last once more, as in Italy, shine from a clear sky; furthermore, he should bring heat and contagious diseases, so that more church livings fall vacant by deaths and thereby new revenues accrue to the Holy See. When Sol with proud calm rejects these requests of the "hotheaded little man," and Phaethon in youthful indignation calls down to him some pithy and bald truths, then the Cardinal in pompous rage pronounces the excommunication against the two heavenly travellers, but in return is delivered by them to the contempt of the world. Phaethon: "I give you over to the ridicule of the Germans, whom you are plundering, that they may chase you away in scorn." Sol: "Leave the wretch alone. It is time to turn our chariot downward and to give room to the evening star. Let the villain down below lie, cheat, steal, rob and pillage at his own 
risk." Phaethon: "Yes, and go to the devil, too. So then I spur the horses on our downward course and follow westward."

The second of the above mentioned dialogues, "The Bull Killer" 1 reminds one of the clownish brawls of a medieval farce. But it is a farce imbued with mighty passion and moral pathos; and, as in Holbein's " Dance of Death," here also medieval conceptions are made the vehicles of a thoroughly modern feeling. The bull of excommunication issued by Leo $\mathrm{X}$ against Luther appears here in person, as a fat, bloated monster, that attacks with threats and blows a beautiful woman, German Freedom. Freedom is too delicate for this passage at arms; she can oppose to the maltreatment by the fiend nothing but laments and calls for help. But finally upon her call: "Does no one dare to succor me, is there no true freeman, no one who strives for virtue, loves the good, hates deceit, honors justice, abhors sin - in a word, is no German there " - upon this call there appears, like a knight of Saint George, Ulrich von Hutten himself. "This call, from whomsoever it may come, concerns me" - with these words he presses upon the brute, which now, first cursing, then whining, tries to defend itself. But in vain,

1 Loc. cit., iv, $3 \mathrm{II}$ ff. 
for Hutten comes from that "shelter of justice," the Ebernburg, "where the men are true men, where one keeps one's covenant, preserves faith, worships the divine, and protects innocence," while in Rome, whence the bull comes, the contrary of all this is the case. "If it were only a question of Luther," he exclaims, "I would let you go, but you attack not only his life, but that of her here, German Freedom; and therefore you must be deprived of your own life." Now there ensues the climax of the action. The bull, writhing under Hutten's merciless strokes, left in the lurch by all his superstitious German adherents ("For Germany now sees with her own eyes "), beseeching his victorious opponent on his knees for mercy, finally in greatest distress makes a last deceitful attempt to save himself. He offers indulgence and papal absolution to perjurers and murderers, robbers and desecrators of churches, adulterers, fornicators and blasphemers, if they only will help him - and, lo, first it seems like an army of fleas, then of ants, then of cats that moves on from the distance; it is the Roman courtiers and mercenaries pressing over the Alps. And now Hutten summons his warriors. "Come, ye freemen; our common concern, the common weal is at stake. Here the tyrants will be crushed; here the servitude will be 
broken. Where are the freemen, where are the illustrious ones, the men of great names, where are ye, heads of nations ? - They have heard me - a hundred thousand I see, at their head my friend, Sickingen. The gods be thanked! Germany has come to herself; even Emperor Charles is here, and all the princes about him. How, now, creature of Leo ?" The Roman courtiers and their army flee; and Franz von Sickingen, who now comes forward, in a mighty speech of triumph once more sounds all the patriotic feelings and hopes with which Hutten's own soul was filled. "The gates of freedom are opened, let us press on. God has unjustly destroyed the people of Sodom and Gomorrah, if he spares the people of Rome, in comparison with whose godlessness they were innocent babes. Let us at last fulfill what thus far seemed impossible. But I make the vow: if Christ will help me to do that which I have in mind, I will spare no labor, and will not give up, until the accursed courtiers, the godless Romans, find no more game in Germany." With a last desperate exertion, the bull turns to the Emperor. Rejected by him also, the wrathful beast bursts in two, and from his belly there proceeds a vapor of poisonous vices. The dragon is dead.

The last of these three dialogues, "The Robbers," " is not the equal of "The Bull Killer" and

${ }^{2}$ Loc. cit., iv, 363 ff. 
"The Spectators" in concentrated power and dramatic weight. But we are compensated for this by the impressive, free and human manner in which the fundamental thought of this dialogue, the necessity of an alliance between the knighthood and the cities for common warfare, is brought out. At the beginning of the colloquy such an alliance seems far off. Hutten, the Hotspur, has got into a squabble with a merchant, a business manager of the great banking house of the Fuggers, on account of the latter's thesis that the. knights were the true disturbers of peace in Germany, that they were highwaymen and robbers, and that the Emperor could not do anything better for the country than to stop their trade. Hutten is on the point of breaking the ribs of the business man, whom he contemptuously addresses as a "Peppersack," when Franz von Sickingen enters and with disinterested composure exhorts the hotheaded Hutten to moderation, and then himself. undertakes the defense of the knighthood against the merchant. He does not deny that there are some knights who live from pillage and robbery, but, he thinks, they are disavowed by their own class. The nobility as a class consider it their highest duty to guard the public peace, to help the weak and to protect the innocent. But the worst 
robbers in Germany are not those occasional highwaymen and bushwhackers; they could easily be subdued; the worst are - "The monks," interrupts the irascible Hutten. "Wait," says Sickingen with superior calm, "I leave them to you for later treatment. First I must speak of the merchants themselves." And now there follows a discussion, resting largely on stoic principles, about the destructiveness of the greed for money, of the over-cultivated city life, of luxury, of the consumption of nerve-exhausting stimulants; and popular invectives against usury, against foreign fashions, but above all against the extortion of the common people by the monopoly of the great corporations like those of the Medici and the Fuggers. "They are worse robbers than the robber-knights," says Sickingen, "but still worse are the scribes and lawyers; for they are the people who at the courts of the princes and in the councils and court-rooms of the cities, instead of the cause of the people, follow only their own private gain. They had Emperor Maximilian entirely in their power, so that nothing came of all his plans of reform. Now they begin the same intrigues with Emperor Charles. They pervert the law, they conceal truth, they deceive the people by sham trials, out of which they alone make money. A court fool is better 
company for a prince than such a sneaking scribbler and quibbler. And it would be better, if these doctors of law with their red caps, who make the greatest difficulties over the most insignificant trifles, and out of their mountains of books bring nothing but confusion of law, had never come into the country, and if the people, according to our ancestral traditions, were their own lawmakers and judges." The merchant listens with ever growing interest, and finally assents with full conviction to Hutten's wish that this vicious brood of law perverters be exterminated root and branch. But now Hutten cannot be restrained any longer. Together with Sickingen he falls with tempestuous fury upon the worst and most wicked of all robbers, the monks, the bishops, the cardinals, the pope and his courtiers. - Against all these robbers, all these exploiters of the common man and of the German Empire (this is the end of the dialogue) the people must make a common cause; to that pledge the merchant and the two knights give one another the hand. And Hutten closes with the solemn words of consecration: "May Christ, the Lord and Saviour confirm this covenant, and may He grant that our examplefind a mighty following throughout theland."

Did Hutten, apart from his incessant endeavors to unite the emperor, the princes, the knights and 
the cities into a great alliance for freedom, think of drawing the peasants also into this formidable union for progress? It almost seems so. For in the dialogue "The New Karsthans" which, although not written by Hutten, unquestionably reflects his thought, such plans are mentioned. But be this as it may, so much is certain: no writer of his time has looked at German national conditions from so high and broad a point of view as Hutten. None has contemplated so radical a national regeneration as he.

It is difficult to do justice to this man so prematurely snatched from life, to this restless spirit who conceived so much, and began so many things. He himself once said that it was the fate of Germany to be unhappy. ${ }^{1}$ If one understands by happiness above all the consciousness of success, then this was the fate of his own life; for the feeling of the goal attained was denied him. But if to be a man means to be a fighter, and if endeavor is the true measure of the greatness of character, then Hutten is one of the greatest and most human characters in German literature. How much in him seems to anticipate the great spirits of a later time! With Lessing he shares the restless striving for truth and the indomitable courage of truth. $\mathrm{He}$ is

1 Miseram oportet esse Germaniam necessario; loc. cit., iv, 384 . 
akin to Heinrich von Kleist in his contempt of compromise and his unconditional surrender to a cause. Something of Ernst Moritz Arndt one seems to feel in his romantic enthusiasm for German nationality and his defiance of foreign fashion. His historically unfair and yet historically justified hatred of the clergy reminds one of the excessive superciliousness of Nietzsche. His delight in cavalierlike sport, his pleasure in country life, his Junkerlike hatred of cities, and his fervent passion for Germany's unity and greatness associate him with the greatest German Junker of the nineteenth century, Bismarck. Nay, one of the very most recent social tendencies, the temperance movement, finds energetic expression in his eager invectives against the German national vice of intemperance. What could this man not have accomplished, what might he not have become for Germany, if there had been more men like him, if his age had been more friendly to him, if he had succeeded in carrying public opinion.

That he by no means was a mere enthusiast or a mere destroyer, but also a man of constructive thought, our whole survey of his activity must have shown. But that with a successful carrying out of his thoughts he would also have learned moderation, is made probable by two of his last dialogues, 
"The Warners." In one of them Luther appears, in the other Franz von Sickingen, both, in order to justify themselves to a friend for their attitude in the great concern of the times, the reformation of the church, and both do this with the greatest objectivity and restraint, although with entire decision and complete trust in their cause. Luther sees his task in leading the church back to the simplicity and inwardness of oldest Christian times; and Sickingen also refutes the accusation of his being an innovator, for him also the main question is the restitution of the true faith in place of superstition, of the religion of Christ in place of that of his Vicar at Rome.

What a view is opened by the thought of the possibility that it might have been granted to Hutten to carry through the war for this cause at the side of Luther, as he had hoped! If the aristocrat and the man of the people, the knight and the son of the miner had really understood each other, if the religious Reformation could have assimilated the ideal of humanity and the rational culture of humanism, if Hutten's thought of an alliance of all classes for the foundation of a free united Germany had been realized, what an age of national greatness and power would then have dawned for Germany! Hutten's own writings, so full of hope, 
stirred by such mighty thoughts, so perfect in form, even in their foreign garb so nobly popular, give us at least a foretaste of what might have been. That Hutten himself, vanquished, deserted, cast out, as a fugitive beyond the German boundaries, sank into his grave, is an impressive symbol of the tragic turn which the fate of Germany took from that moment when the Reformation shook off humanism and thereby, instead of a universally human movement came to be a question of church orthodoxy and theological zeal. But Hutten's figure stands before us transfigured by eternal youthfulness, as the earliest champion of an ideal to which after him many of the best sons of Germany have devoted themselves and which at last, in a more enlightened age, has been at least partially realized: the independence of secular life from the encroachments of clerical authority and the function of the State as the legitimate upholder of liberal culture and spiritual progress.

Was Hutten right when he said that it was the fate of Germany to be unhappy? If he was, and it would almost seem so - then it must be said that the tragedy of German history is most intimately allied with German greatness. Twice within the last four hundred years German na- 
tional life has been nearly crushed at the very moment when it seemed as though the fulfillment of the ages had come; twice there has arisen from this very destruction a new and a higher national culture.

In the sixteenth century Germany gave to the world the principle of religious freedom. But owing to the lack of a broad national spirit and a firmly consolidated public opinion, religious freedom reacted upon Germany not as an upbuilding, but as a disintegrating force. At the end of the sixteenth century, when England was about to enter the Elizabethan era, when the Dutch were fighting the most glorious struggle of modern times for free thought and free government, Germany, the motherland of religious liberty, seemed hopelessly lost in the conflict between Jesuit and Protestant fanaticism and was gradually drifting toward the abyss of the Thirty Years' War. From the ruin and the desolation of this war, Germany gradually and slowly wrestled upward in the seventeenth century. Under the most terrible discouragements, with infinite patience and abiding faith, her citizens, her intellectual and spiritual leaders, and her princes, each in his own narrow sphere, tried to cultivate and to strengthen what there was left of germs of prosperity and of hope for the 
future; and from utter political impotence at the time of Louis XIV at least one German state, Prussia, gradually rose to the heroic achievements of the reign of Frederick the Great.

Then there came another epoch when Germany gave to the world a precious spiritual message. Kant exalted the moral law as the only true revelation of the divine, Schiller pointed to beauty as the reconciliation between the ideal and the real, Goethe found the salvation of man in the restless striving for culture. But again it seemed as though Germany must pay with her own life for the priceless treasures won by her for humanity. Her æsthetic and moral culture had become too refined to resist the rude attack of a hostile world. The classic epoch of German literature and philosophy coincided with the breakdown of the German Empire and the subjugation of the German people by the French conqueror.

From the throes of this fearful catastrophe the Germany of today was born. By summoning all her powers, - physical, intellectual, spiritual, against the ruin threatened from Napoleonic dominion, Germany once more rose to political greatness. A new and exalted conception of the State, a State uniting in itself all spiritual and moral aspirations of the people, stimulating every 
kind of public and private activity, straining every energy and protecting every resource, subordinating all individual comfort to the one great aim of national achievements, inspired the best Germans throughout the nineteenth century. Since I870 it has seemed as though Germany, of all nations, was destined to be a leader in everything that makes for good government, for public honesty, for social justice, for personal enlightenment, orderliness and respectability, for wisely organized and wisely directed peaceful activities of every kind.

And now, for a third time, a fearful cataclysm, more destructive perhaps than even the Thirty Years' War and the Napoleonic invasion - threatens to sweep away everything that has been won by the work of generations; and the possibility of ruin stares Germany in the face.

But if history teaches us anything, it certainly teaches us that a people which remains true to its better self cannot be crushed. The present conflict has brought such overwhelming evidence of the German people's determination to sacrifice everything in the service of a supreme ideal demand that, whatever may be the fate of the battlefield, this war is certain to usher in a new and greater epoch of German culture. Never before have Germans, without distinction of rank or class or 


\section{I 6 GERMAN LITERATURE}

party or creed, felt so clearly what it is that makes their national existence, what the ultimate aim is for which they live and for which they are glad to die. This new national consciousness will survive either victory or defeat; it will lead to new national achievements, to new spiritual attainments, to the purging of whatever may be left of weakness or littleness or false conceit in German personality. 
INDEX 



\section{IN DEX}

Alsfeld Passion Play, 131-137.

Amis, the Clerk, 103-105

Arminius, 195.

Arndt, Ernst Moritz, 210.

Augsburg, Diet of, 200.

Bach, Sebastian, 88.

Ballad, popular, 90- 99 .

Bamberg, sculptures at Cathedra] of, 84 .

Beguines, order of, 46,47 .

Benediktbeuren Christmas Play, II7-II9.

Bernard of Clairvaux, 58, 59 .

Berthold of Regensburg, 50-58.

Bezold, Friedrich von, 184 .

Bismarck, 2 ro.

Bouts, Dirk, 139, 180.

Brant, Sebastian, 162.

Breughel, Peter, 70.

Bücher, Karl, 79.

Burckhardt, Jacob, 4, 15.

Burgherdom, individualism of, 43-46.

Cervantes, 100.

Charles V, 186, 193, 194, 207.

Chartres, sculptures at Cathedral

$$
\text { of, } 5 \text {. }
$$

Chaucer, ro, ror.

Chivalric ideals, $7,8$.

Chrestien de Troyes, 28, 29, 33, 34.
Cologne school of painting, 70 , 139.

Crotus Rubeanus, $187-189$, 197 .

Dante, 10, 15 .

Dionysius Areopagita, 58 .

Dürer, 28, 72, I38-r5o.

Ebernburg, 194, 195, 204.

Eckhart, Master, 59-64, 72.

Emser, Hieronymus, 155, 198.

Erasmus of Rotterdam, 154-183, 195, 197-199.

his skepticism, 156 .

his rationalism, 157 .

his religious toleration, 158 ,

159.

his efforts for popular welfare, 160.

his belief in freedom of the will, $160, \mathbf{1 6 r}$.

the "Praise of Folly," 162I70.

the "Familiar Colloquies," $171-183$.

Eyck, the brothers van, 70, 72, 99, I39.

Faustus, 153 .

Flemish painting, 84 .

Frederick the Great, 214 .

Frederick the Wise, Elector of Saxony, 194, 196. 
Gengenbach, Pamphilus, 198. Goethe, 19, 22, 64, 77, 90, 191 n., 214.

Gottfried von Strassburg, 36-42. Gummere, Francis, 79.

Hartman von Aue, 22-27.

Hauptmann, Gerhart, 64, 105.

Hegel, 64.

Heine, 96, 137 .

Helmbrecht, Farmer, 105-II4.

Herder, 79, 84.

Hessian Christmas Play, I 23.

Hessus, Eobanus, 155 .

Hoffmann, Amadeus, 64 .

Holbein, 138, 195.

Hugo of St. Victor, 58.

Humanism, ideals of, $151-153$.

Hutten, Hans von, 189 .

Hutten, Ulrich von, I 54, I84-2 I 2 .

his political program, I85-187.

his literary independence, 188.

his patriotic motives, 189Ig2.

his participation in the Reformation propaganda, 193195.

his Dialogues, 198-21 2.

Ibsen, 64 .

Individualism, 43-46, 73 .

Innocent III, 15, 16 .

Jutta, Play of Frau, 2 I.

Kant, 2 I4.

Kleist, Heinrich von, 106, 210.
Kraft, Adam, 84 .

Leo X, 189, 194, 203.

Lessing, 209.

Limburg Chronicle, 78 .

Louis XIV, 2 I4.

Love song, popular, 85-89.

Lucian, 199.

Luther, 16, 77, 114, 160, 161, 174, I85, I93-I95, I97, 2 II.

Manuel, Niklas, 198.

Matilda of Magdeburg, 47-49, 53 .

Maximilian I, 186, 189, 207.

Melanchthon, 154 .

Memlinc, 180 .

Middle Ages, spirit of, 7 .

Murner, Thomas, 162, 198.

Mutianus, Conrad, 155 .

Napoleon, 214.

Naumburg, sculptures at Cathedral of, 6 .

Nettesheim, Agrippa of, 153.

Nietzsche, 44, 77, 2 10.

Paracelsus, 153.

Paulsen, Friedrich, I84.

Pirkheimer, Willibald, 155, I89, 190.

Poe, Edgar, 64.

Preaching orders, 50.

Redentin Easter Play, I 27-I3I.

Reinke de Vos, I0I.

Reuchlin, 154, 180.

Rheims, sculptures at Cathedral of, 5 . 


\section{INDEX}

Richard of St. Victor, 58.

Rogier van der Weyden, I0, 139.

Rousseau, 44, 77, 170.

Schiller, 19, 64, 77, 214.

Schlegel, Friedrich, 165.

Schongauer, Martin, 139 .

Scotus Erigena, 58.

Shaw, Bernard, 166.

Sickingen, Franz von, 194-r96, 205-208, 211.

Strassburg, sculptures at Cathedral of, 84 .

Strauss, David Friedrich, 199 .

Sudermann, Hermann, 137.

Suso (Seuse), Heinrich, 64-73.

Tauler, Johannes, 72-77.

Teniers, I24.

Theophilus, Play of, I 21.

Tieck, Ludwig, 165 .

Tolstoi, 69 .

Tours, Mystery Play of, I I 7 .

Ulrich, Duke of Würtemberg, I89, I93.

Valla, Lorenzo, 189.

Vienna Easter Play, I 24, 125.

Virgins, Play of Wise and Foolish, I 22.

Voltaire, 170.

Wagner, Richard, 30, 93.

Walther von der Vogelweide, 9I9, 83-85, I9o.

Wilde, Oscar, 137 .

Wohlgemut, Michael, 139 .

Wolfram von Eschenbach, 28-37.

Worms, Diet of, 195 .

Zola, 69.

Zwingli, I86, I87. 




\section{UNIVERSITY OF CALIFORNIA LIBRARY}


$R A$

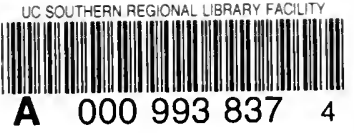


